\title{
Rearrangement of Homoallylic Alcohols induced by DAST
}

Sophie Canova, ${ }^{a}$ Véronique Bellosta, ${ }^{a}$ Serge Mignani, ${ }^{b}$ Antony Bigot ${ }^{b}$ and Janine Cossy $^{\mathrm{a}, *}$

a) Laboratoire de Chimie Organique, associé au CNRS, 10 rue Vauquelin 75231 Paris Cedex 05 - France

b) Sanofi-Aventis, 13 quai Jules Guesde, 94403 Vitry-sur-Seine - France 


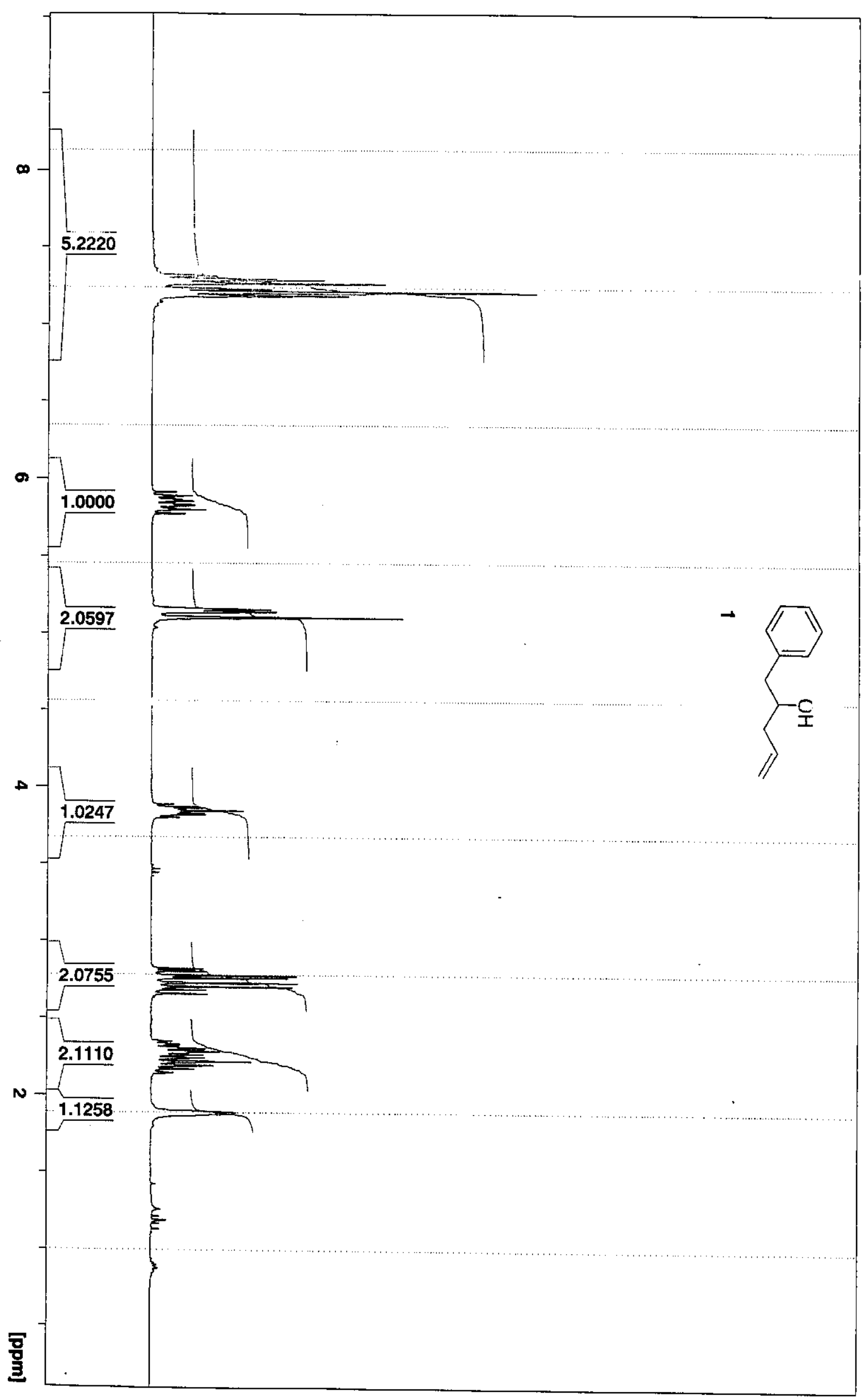




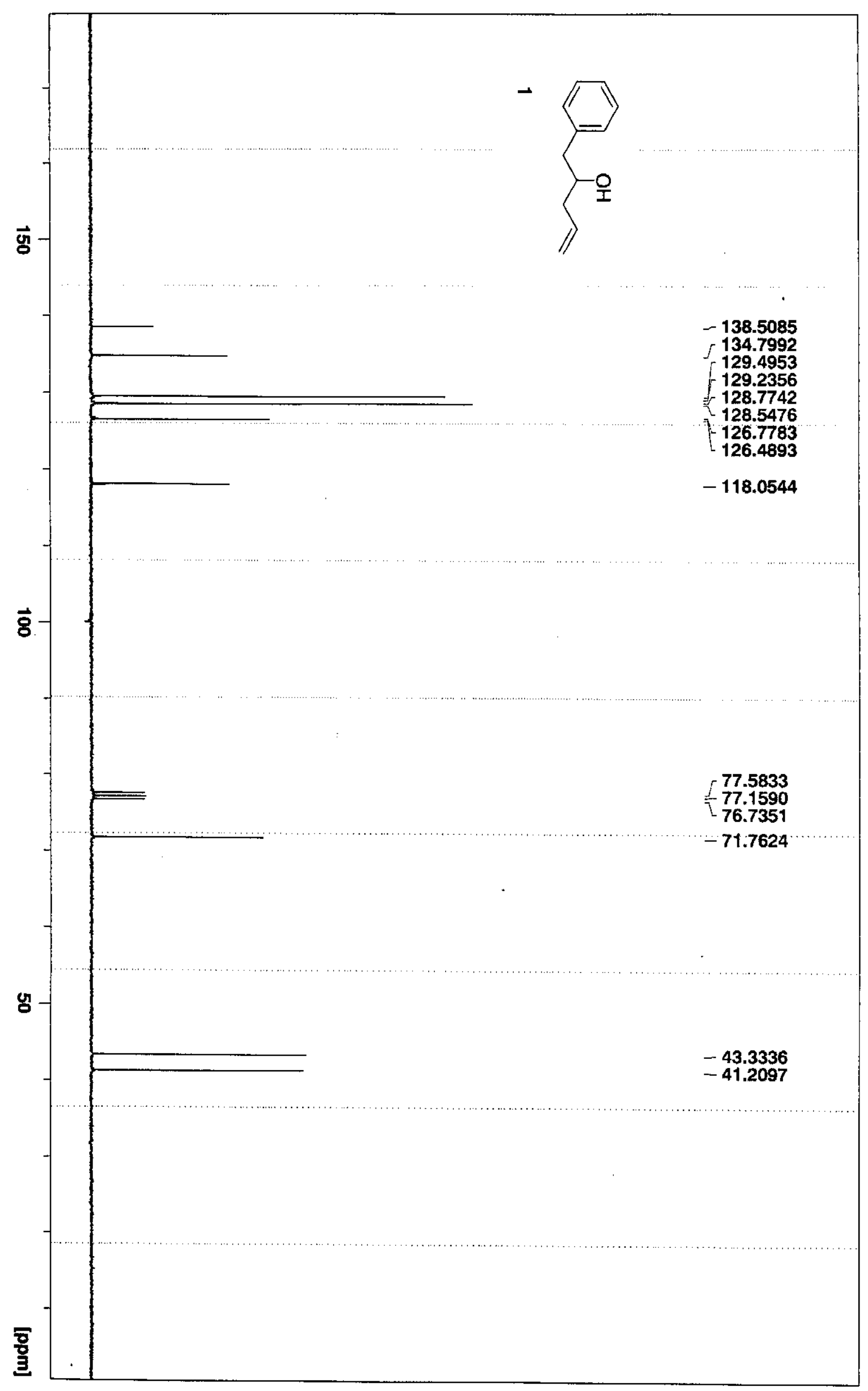




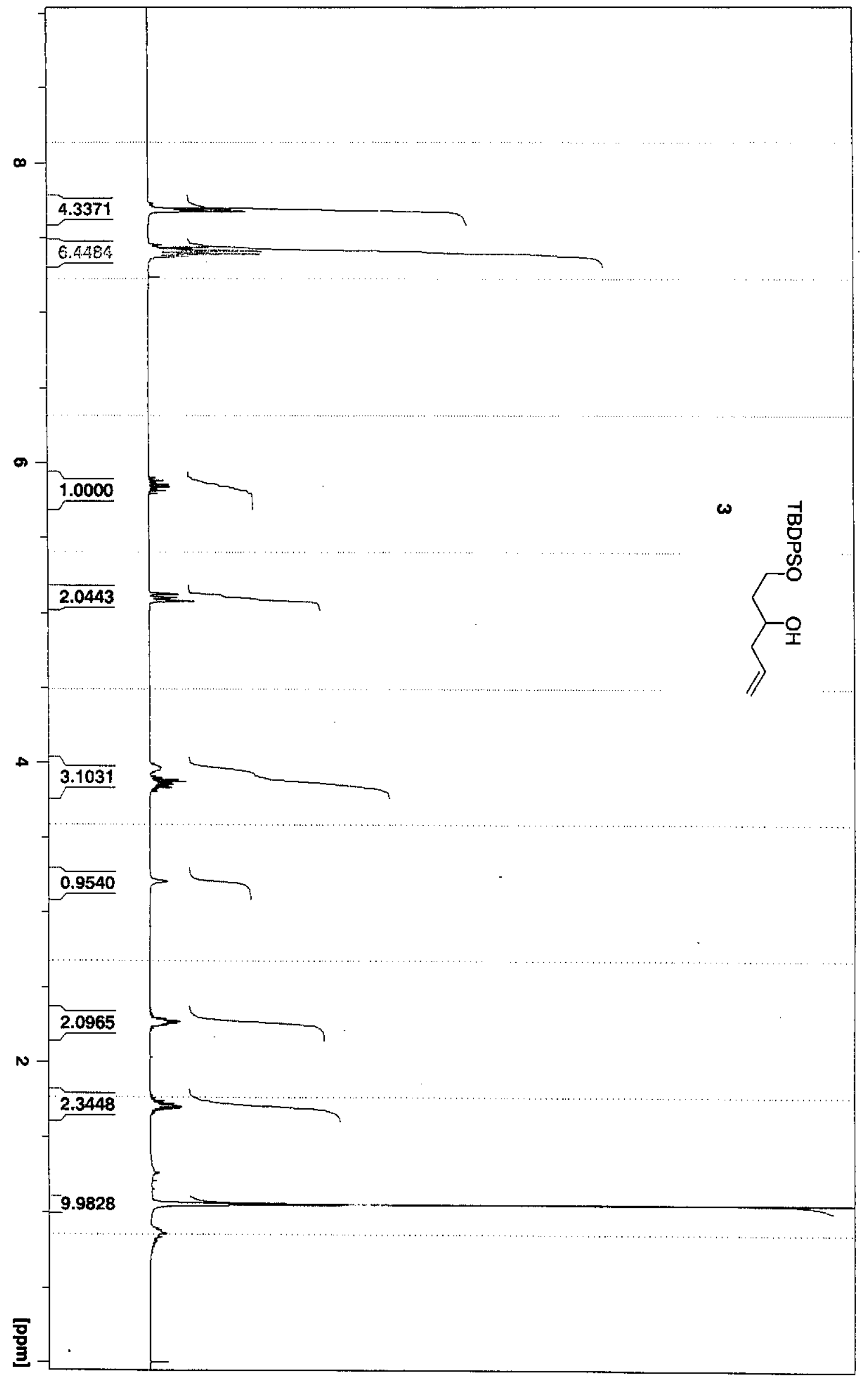




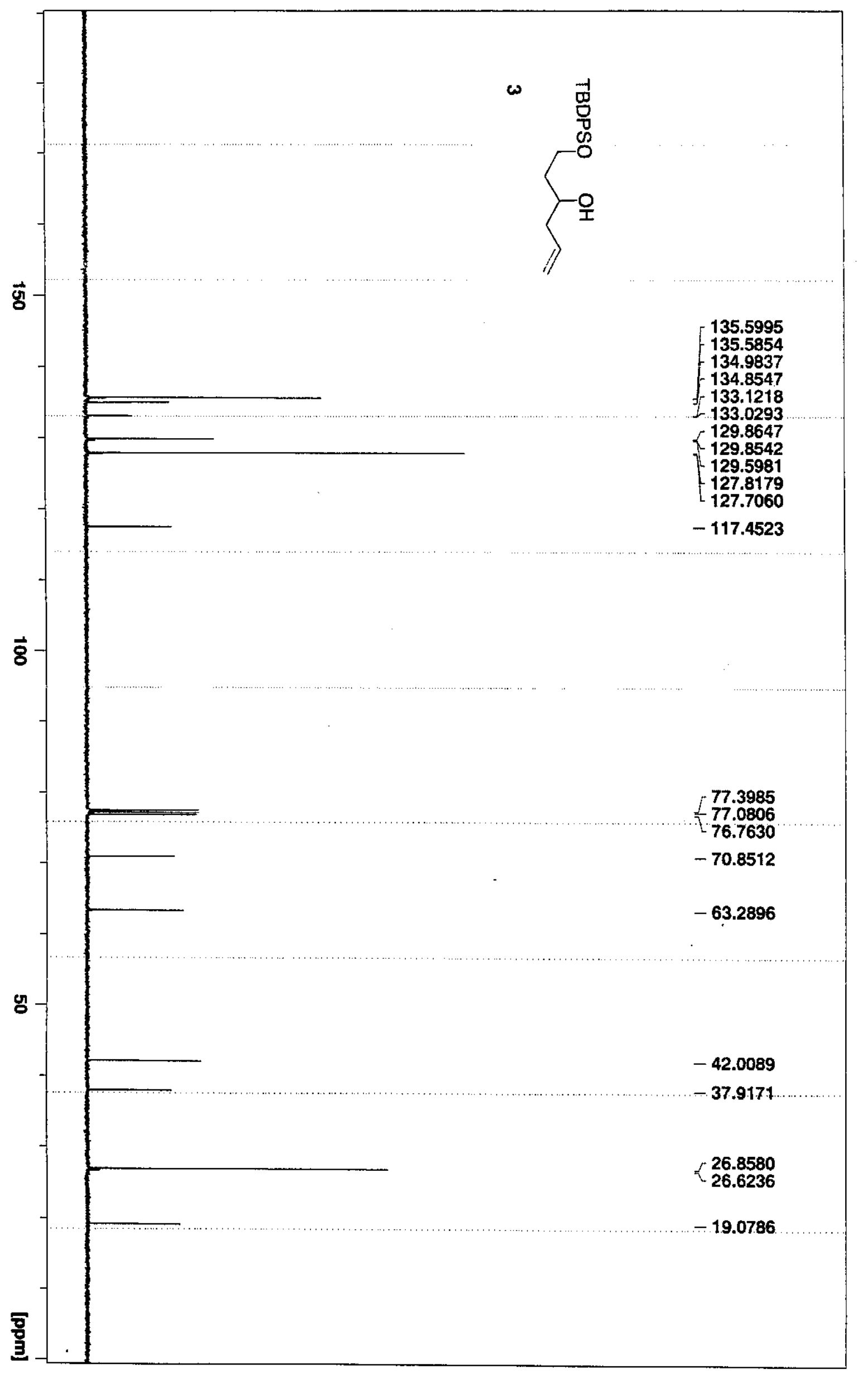




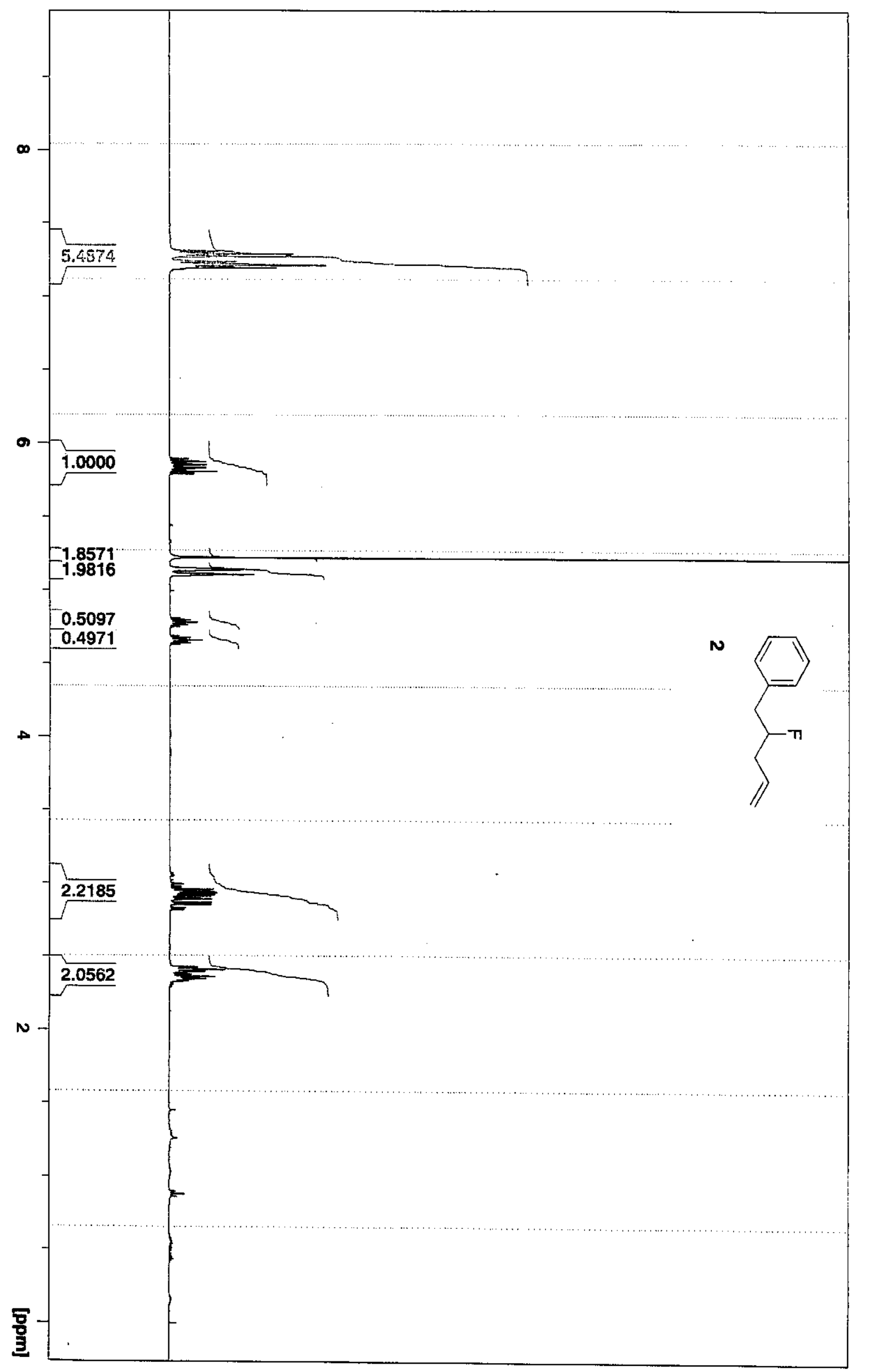




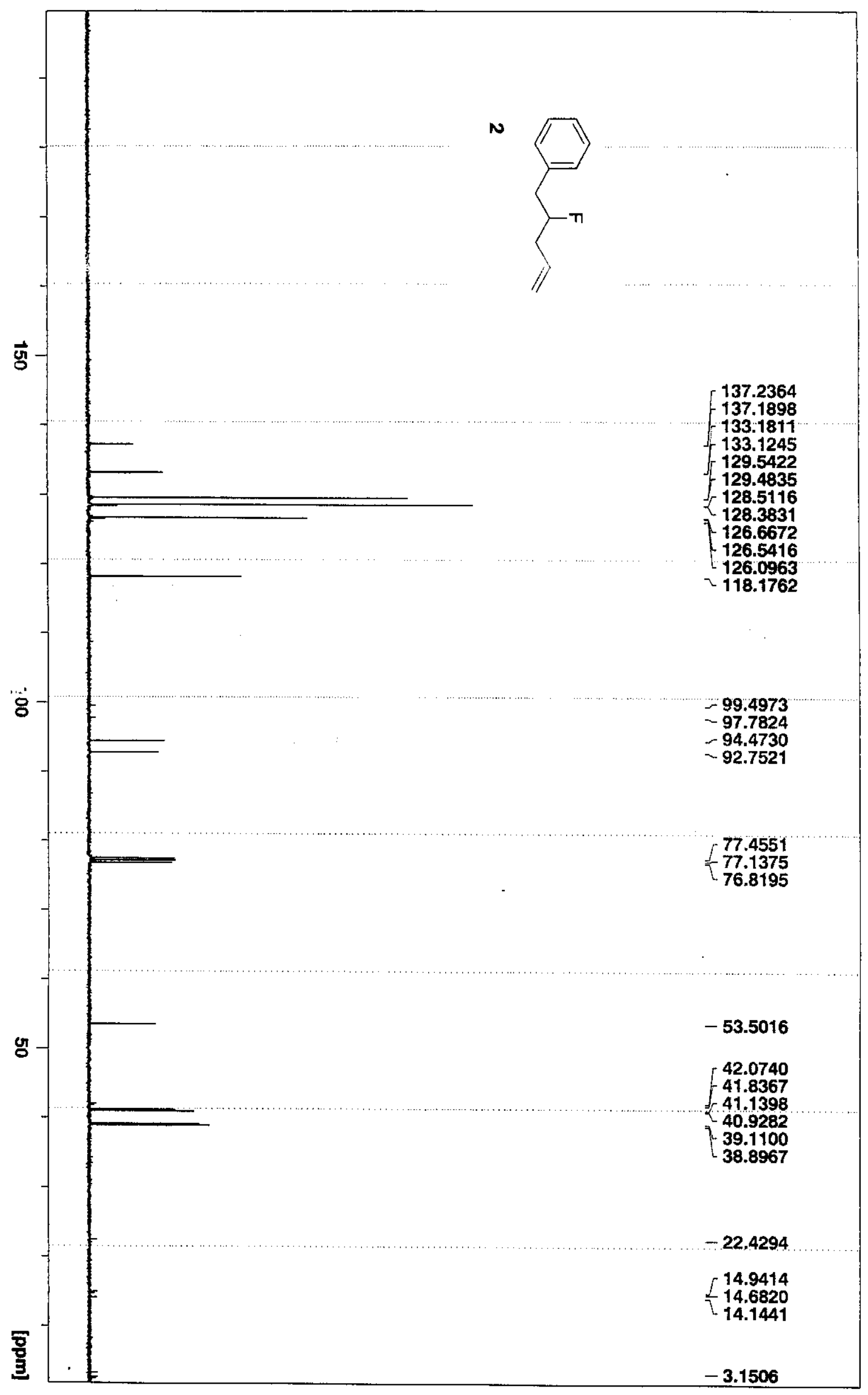




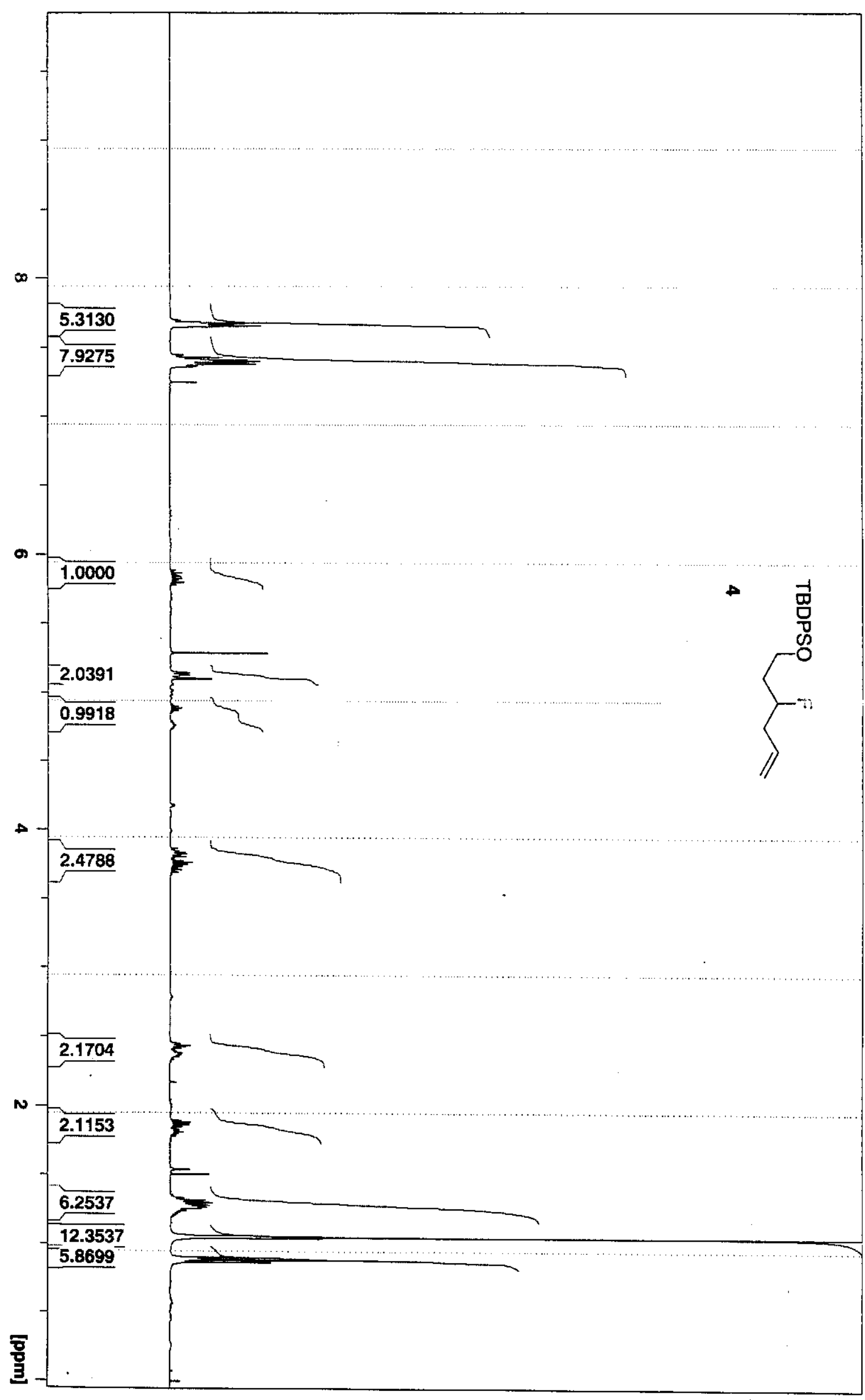




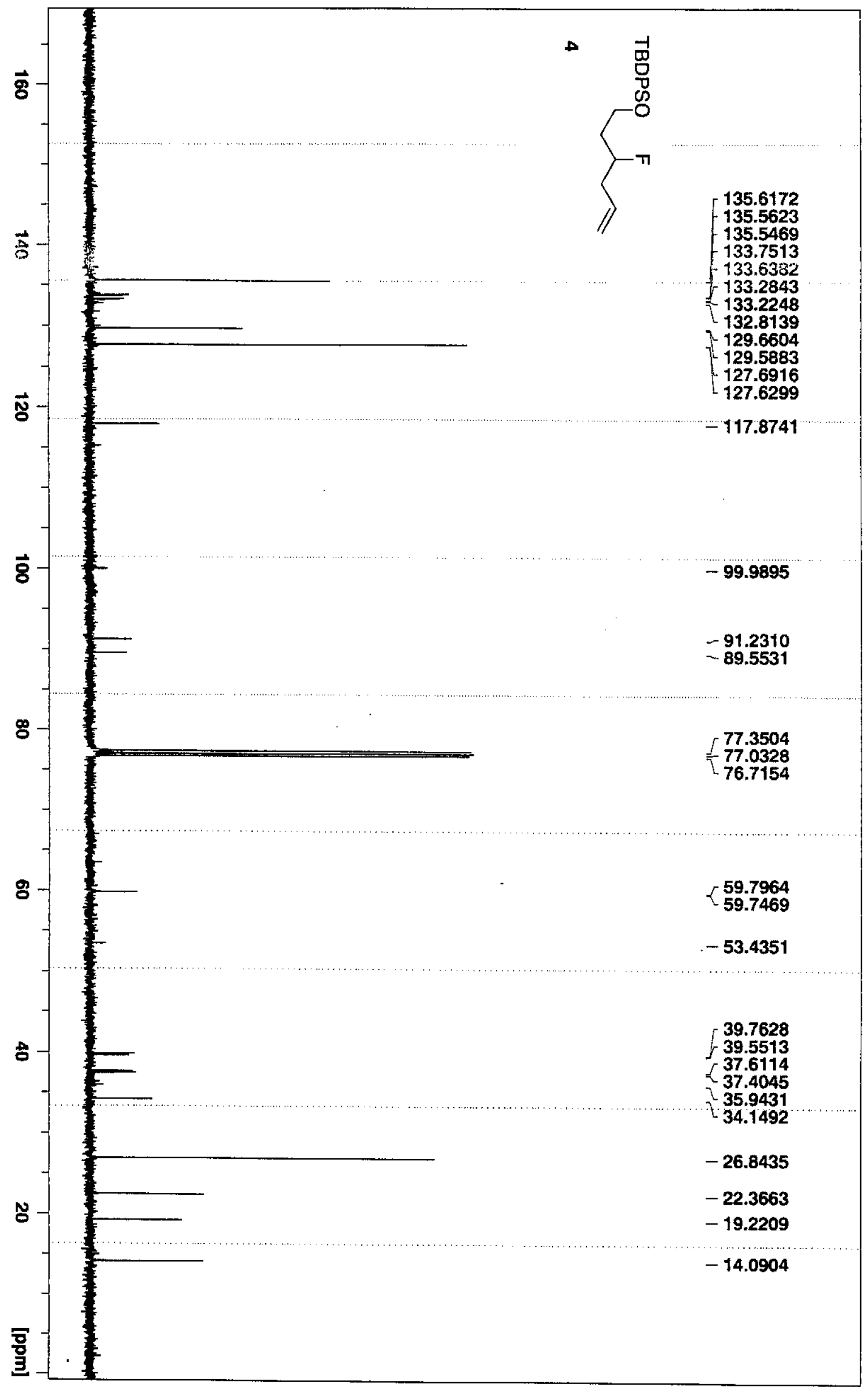




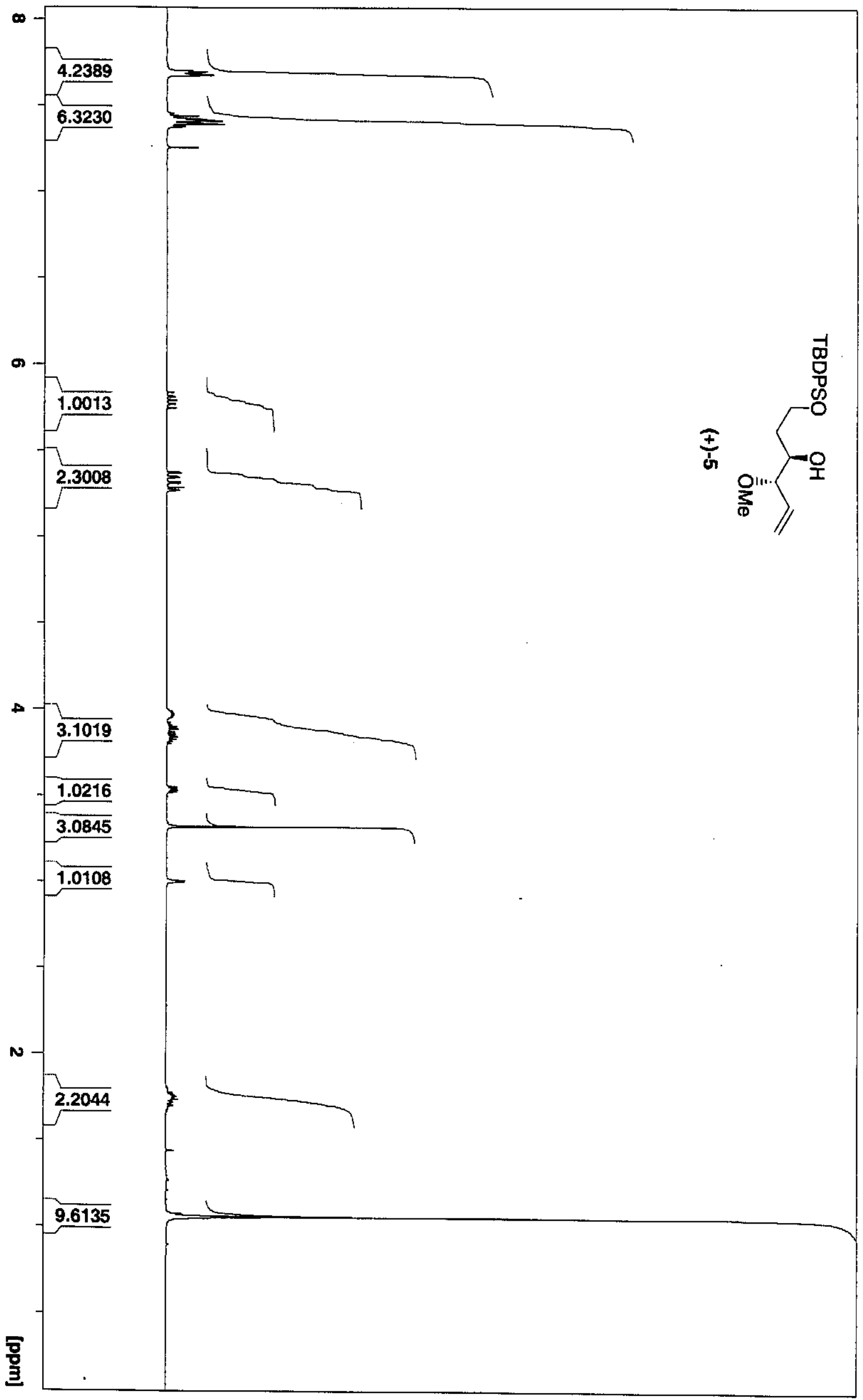




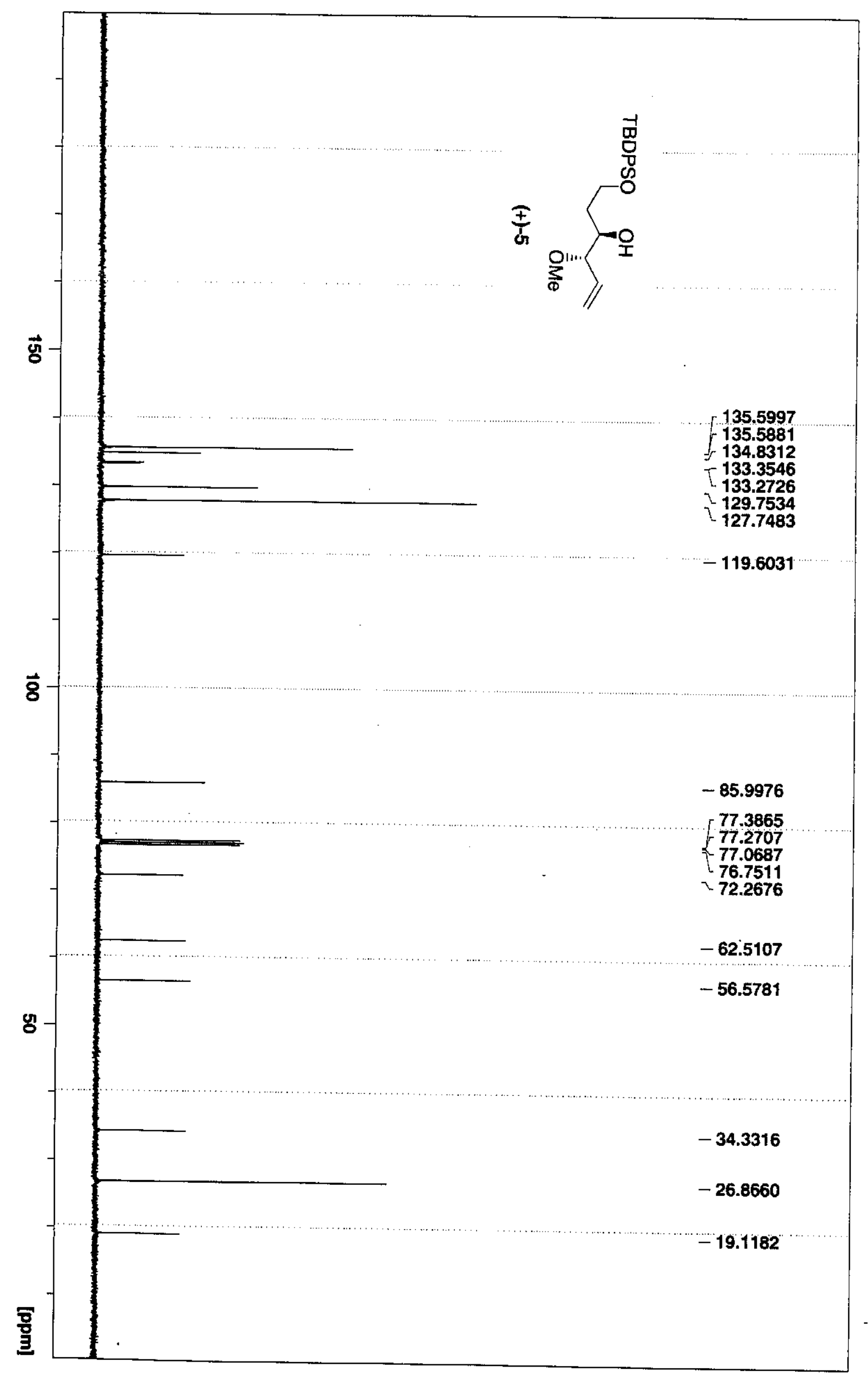




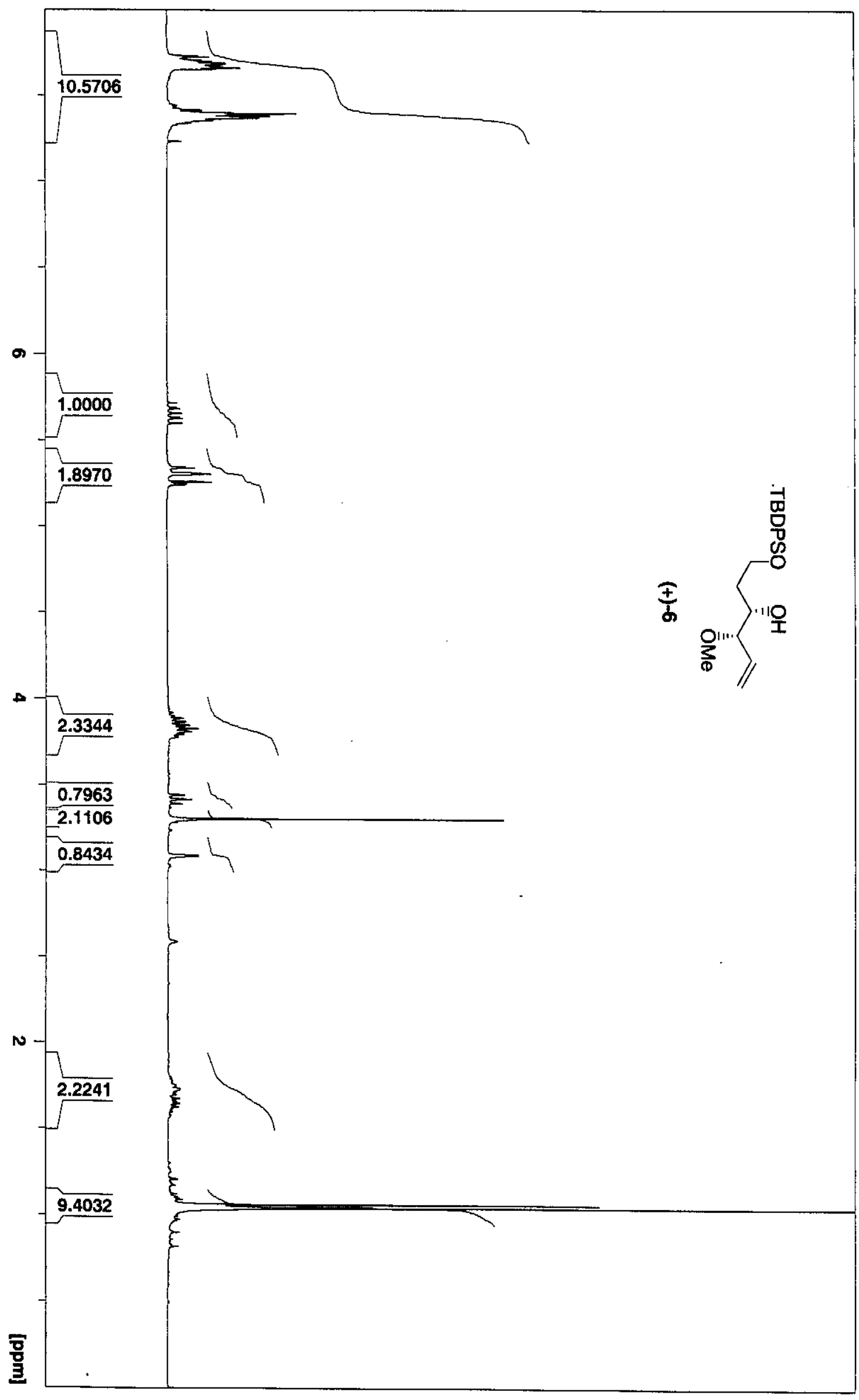




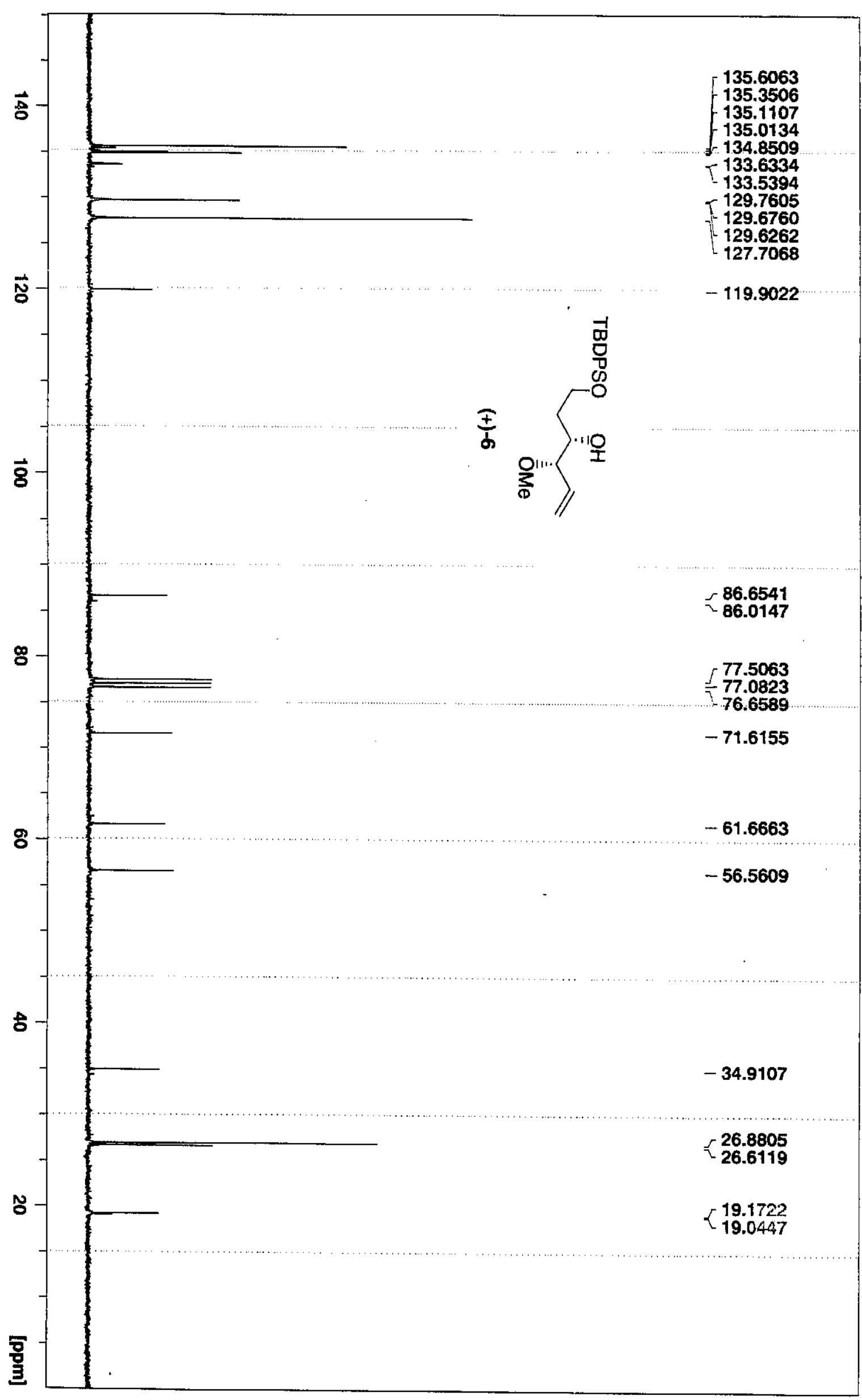




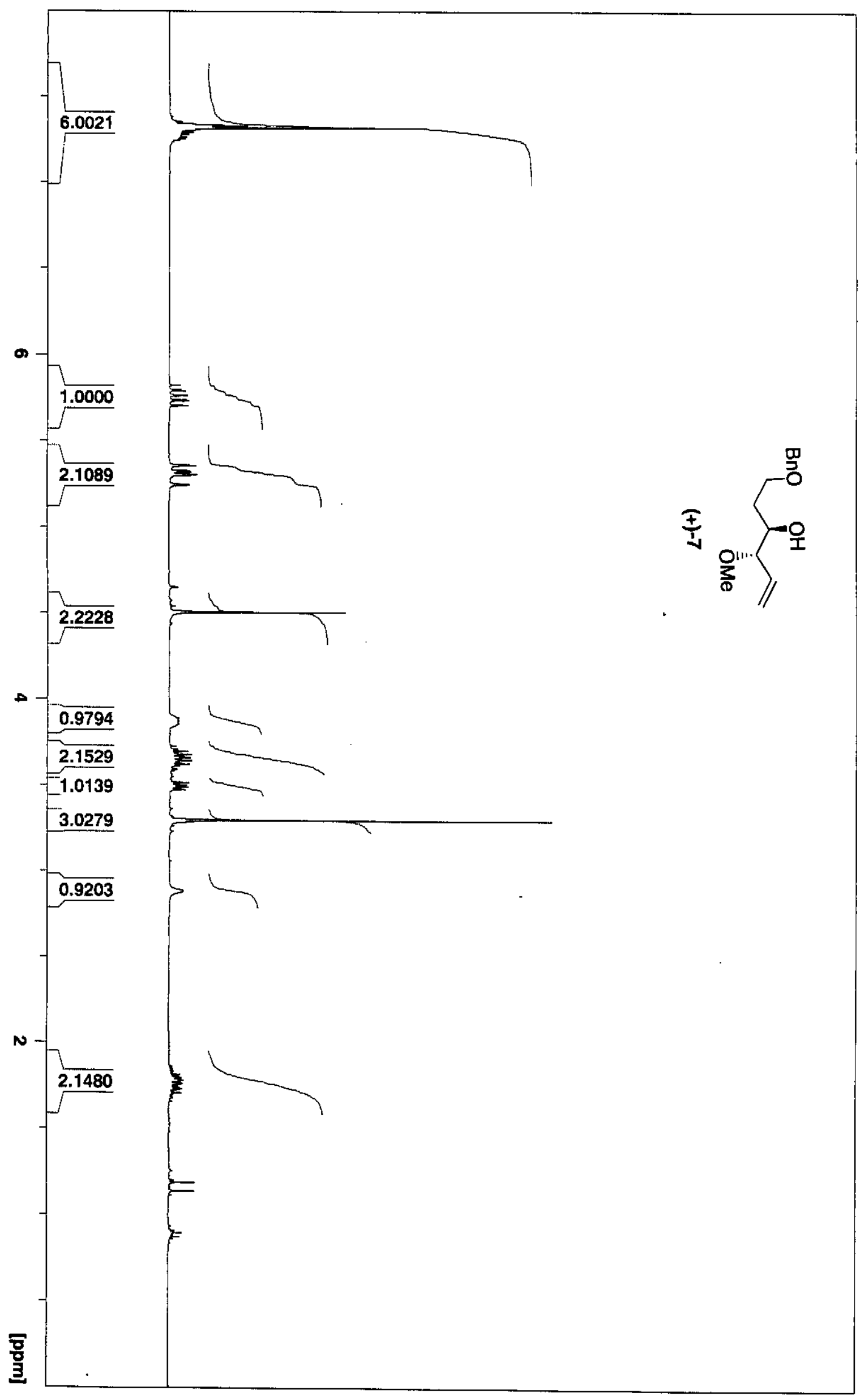




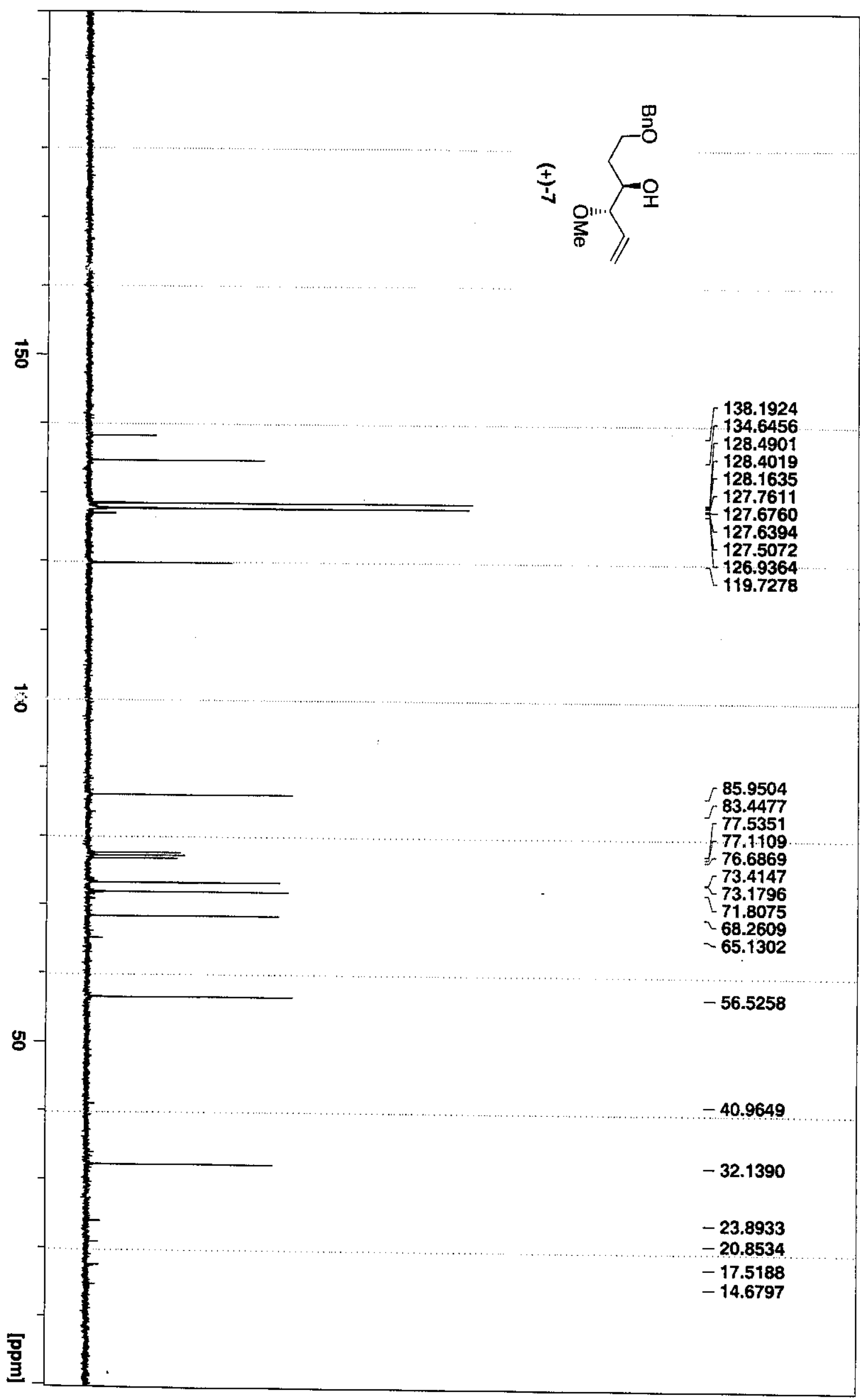




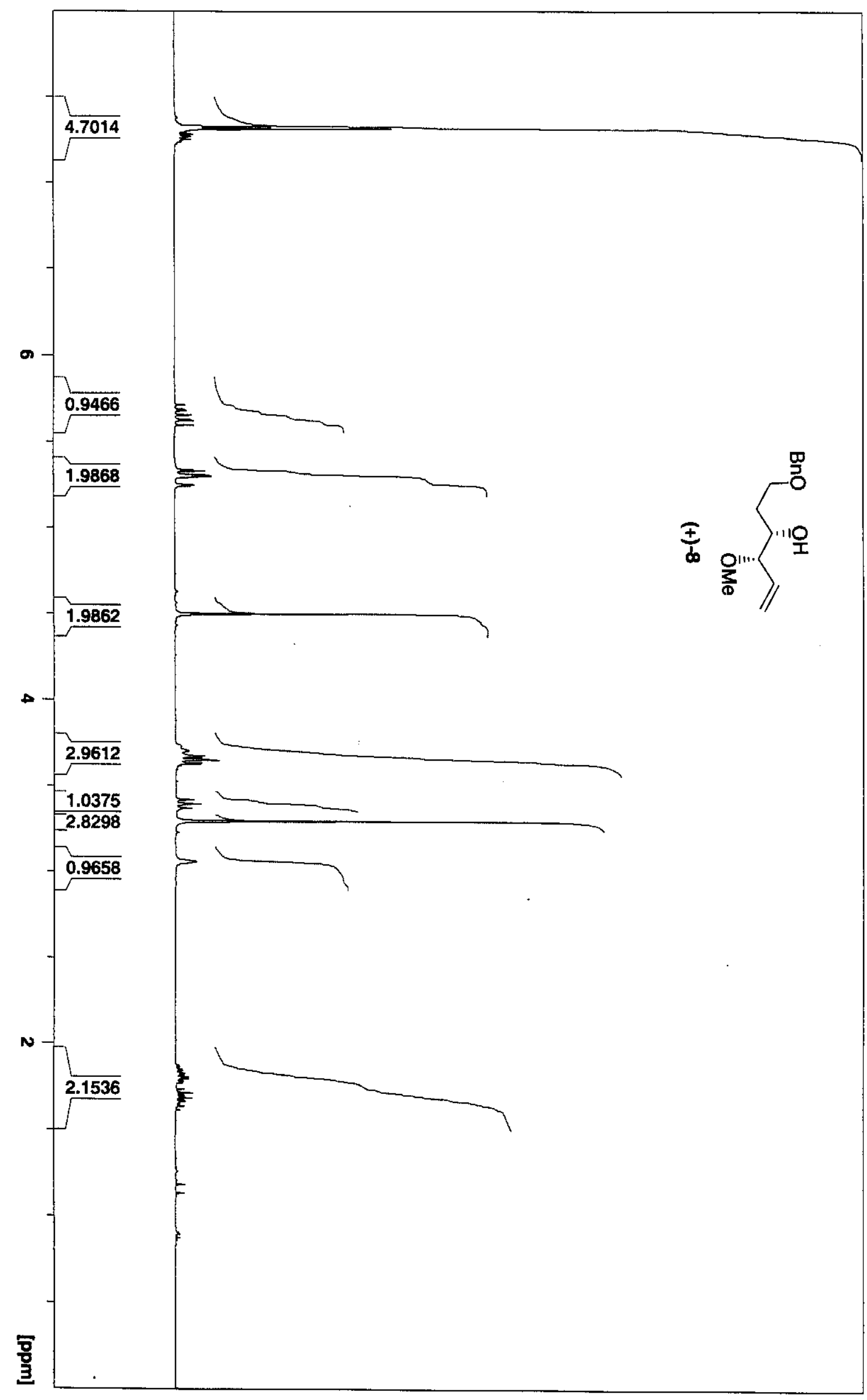




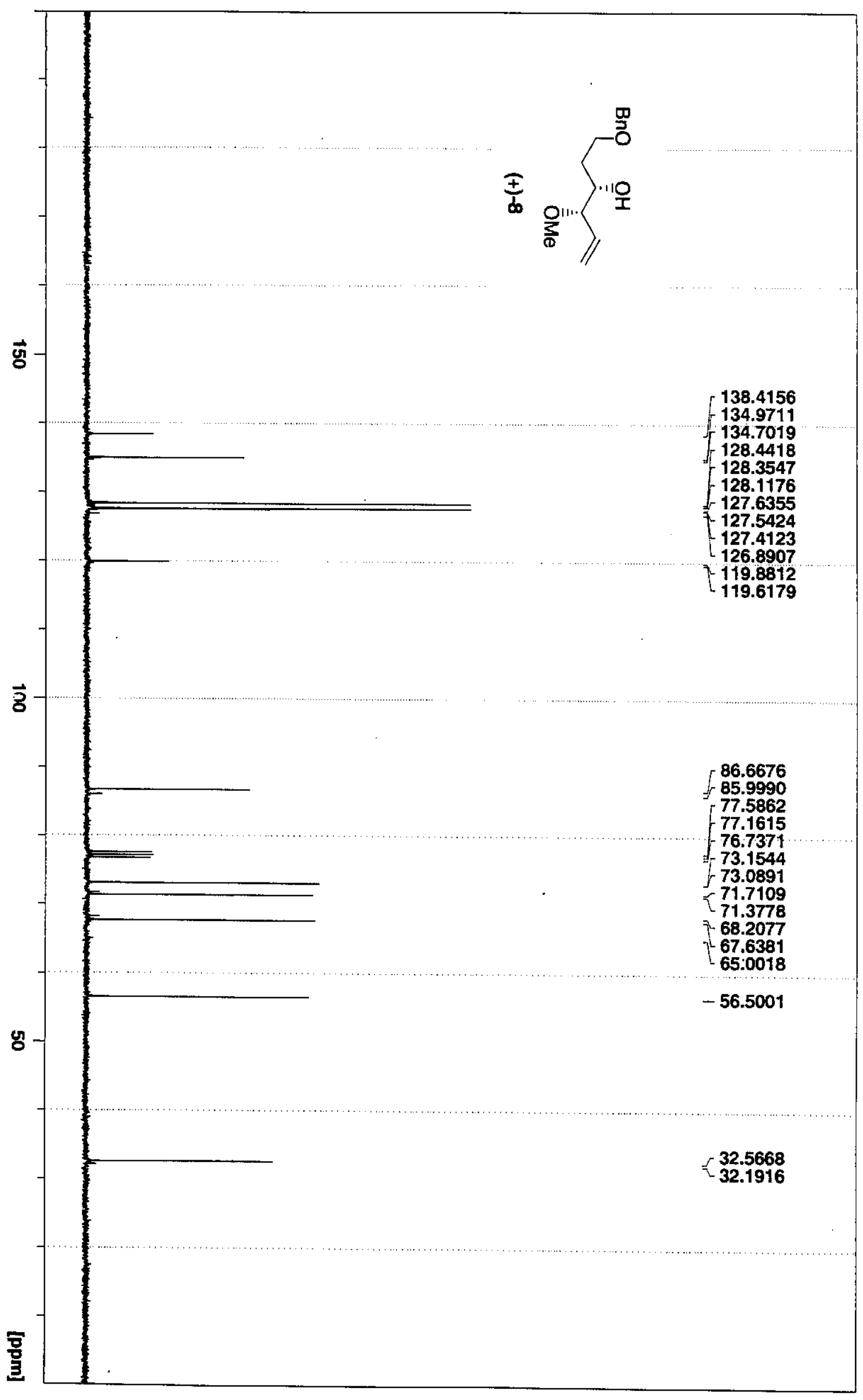




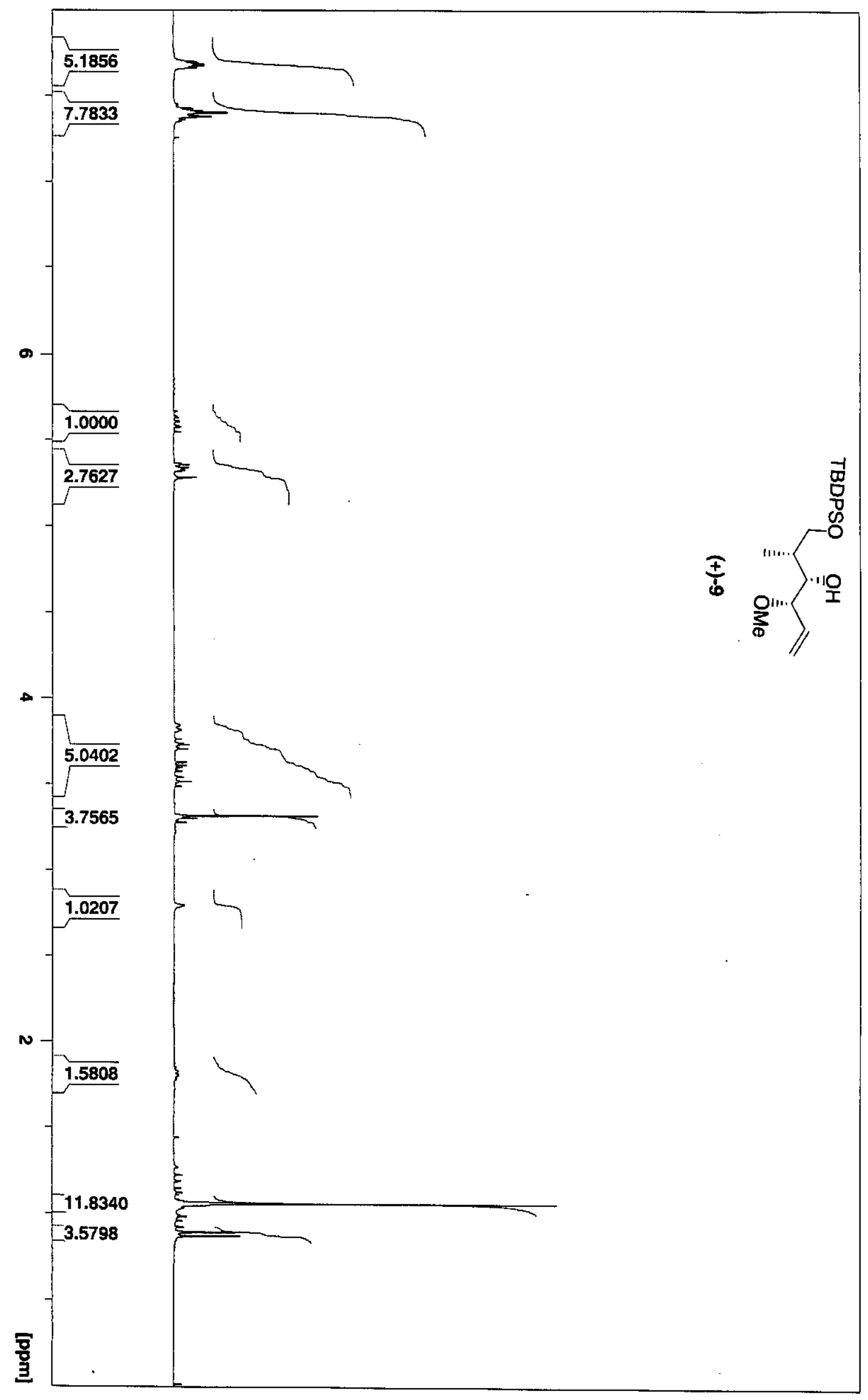




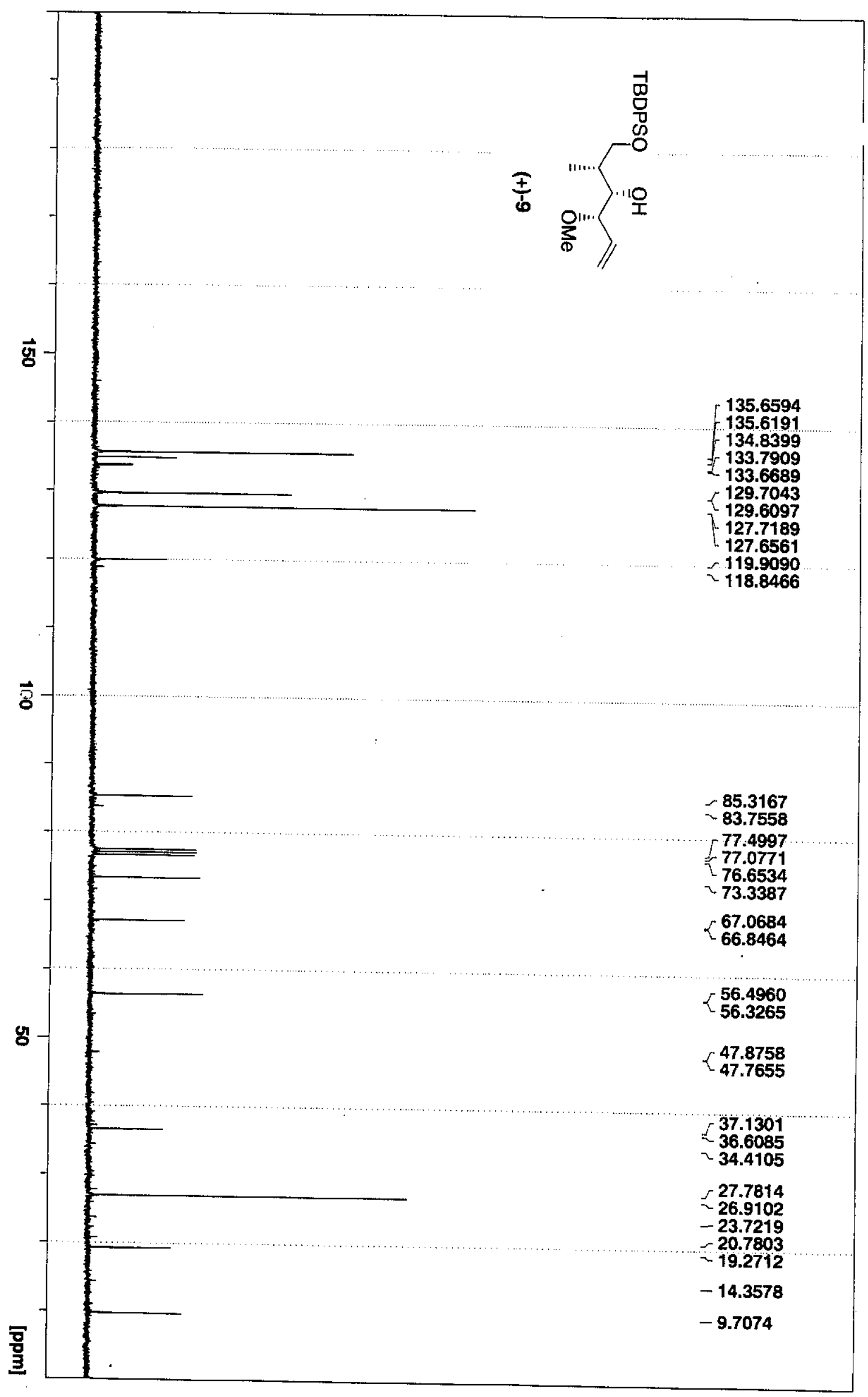




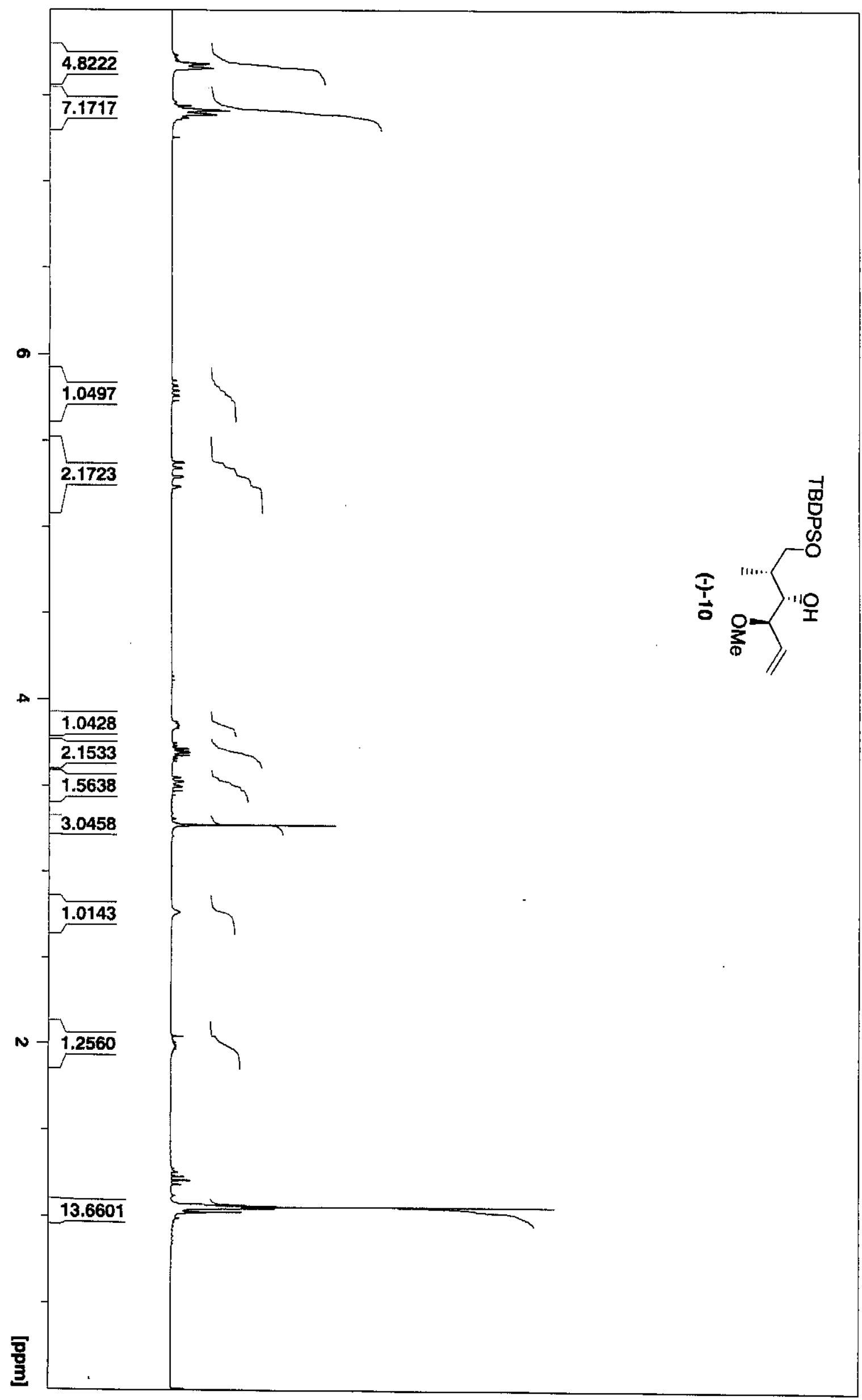




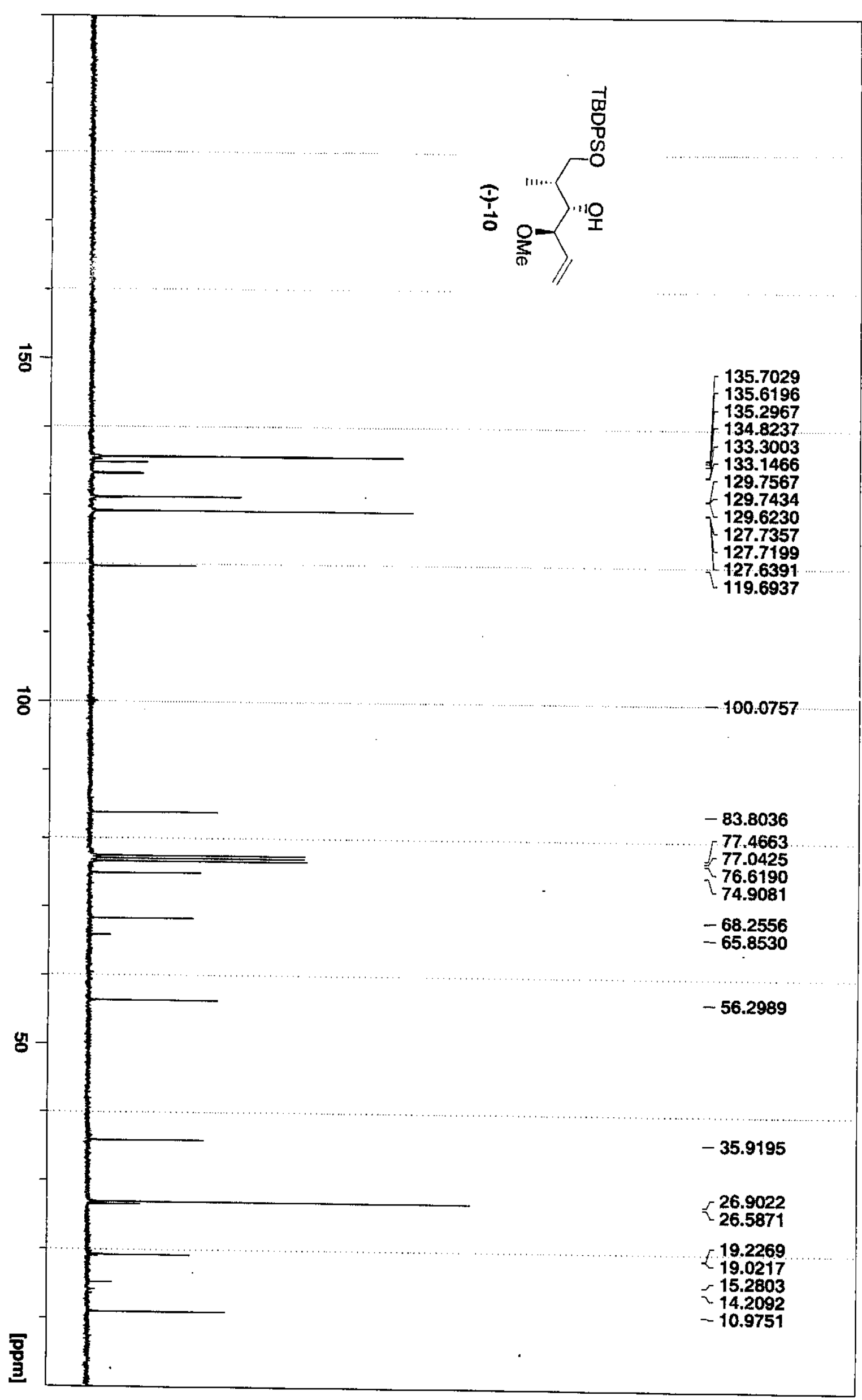




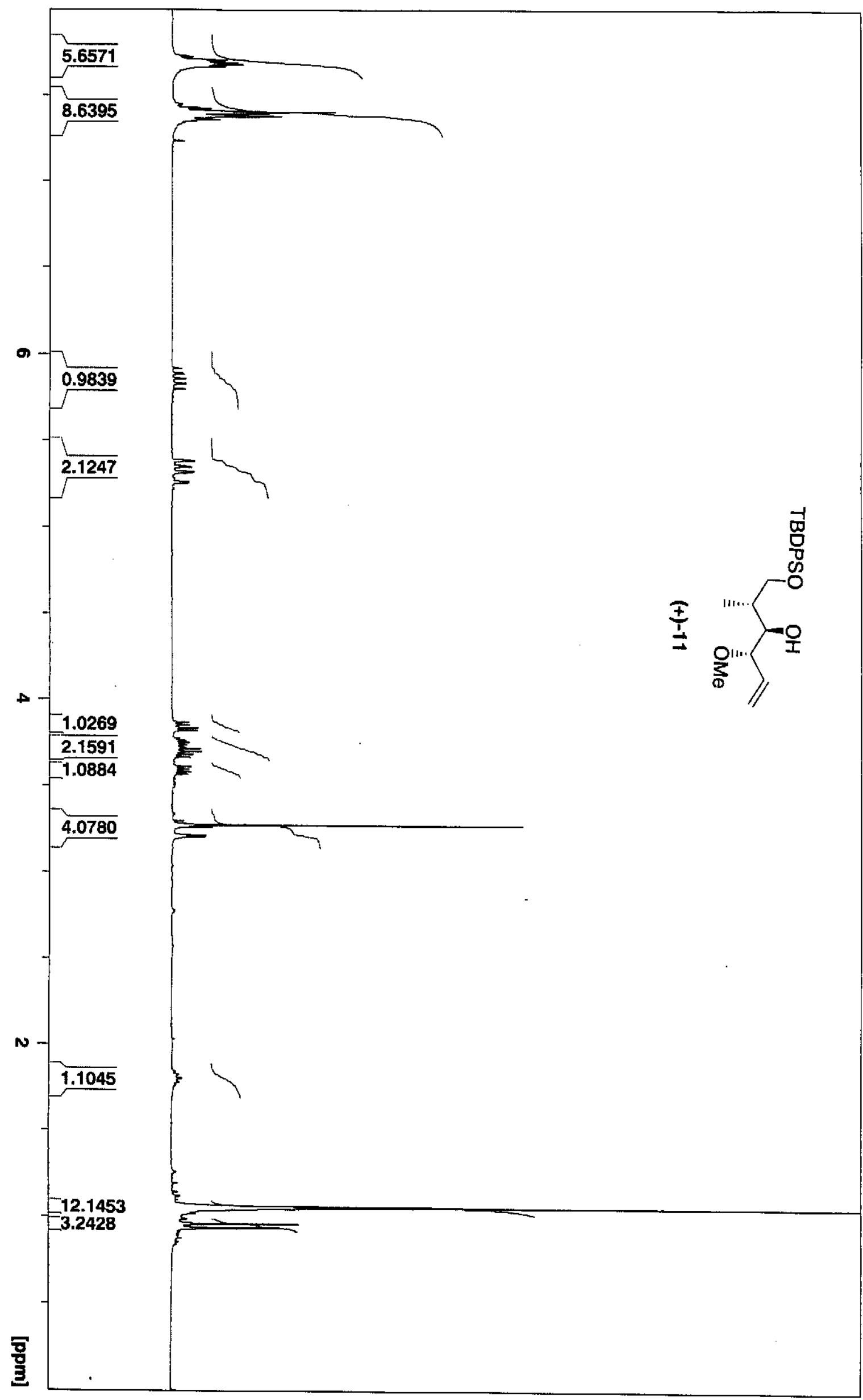




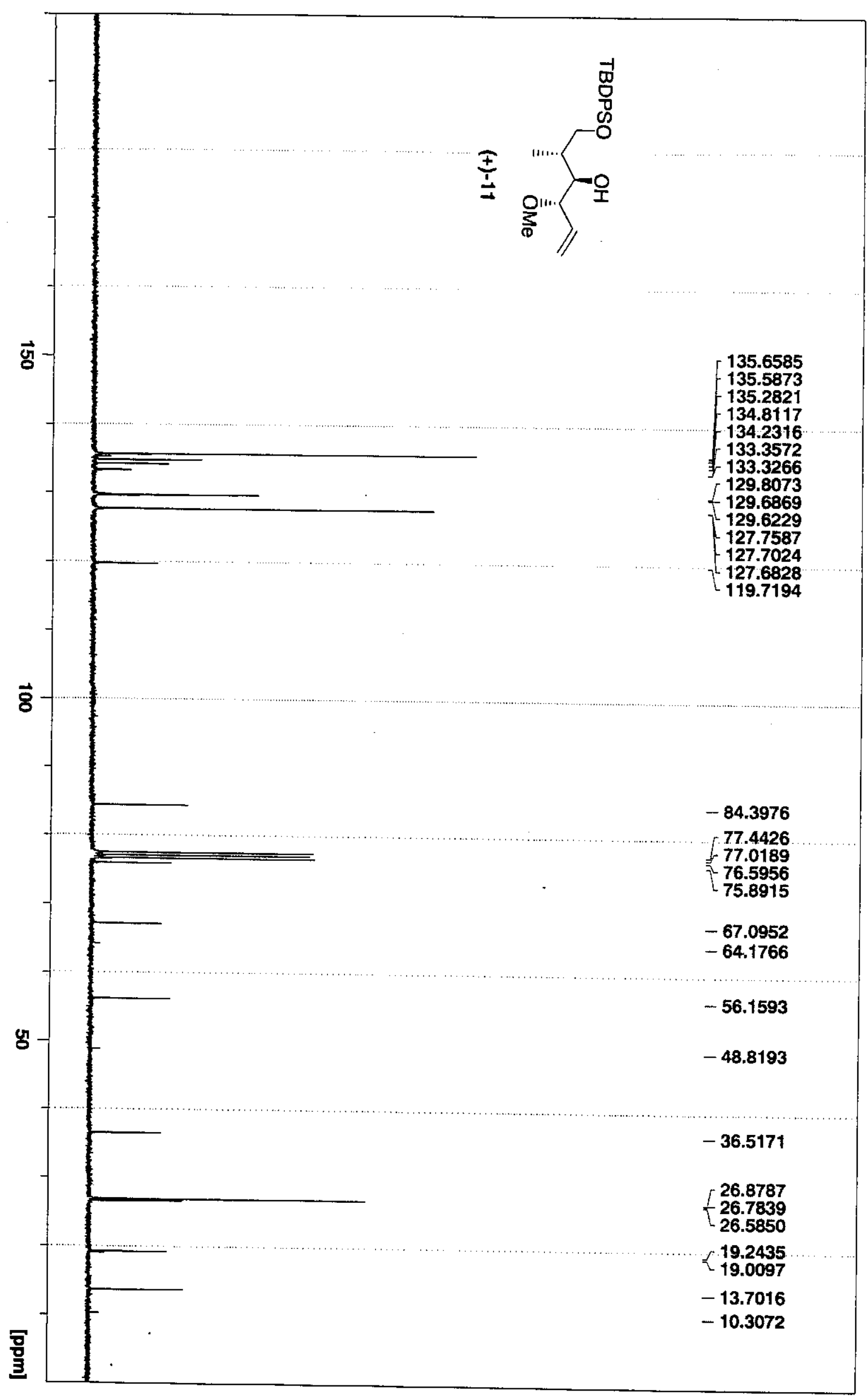




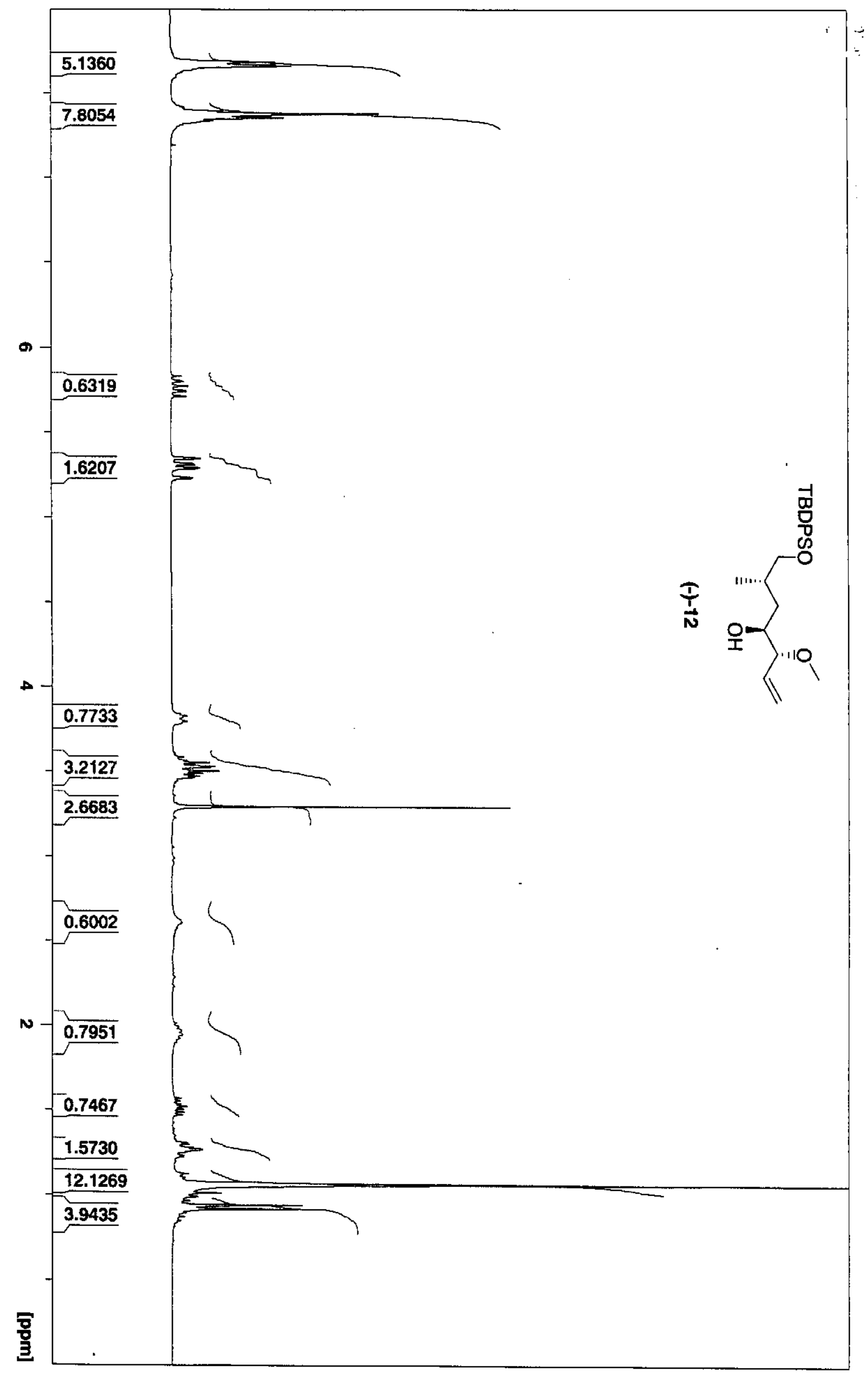




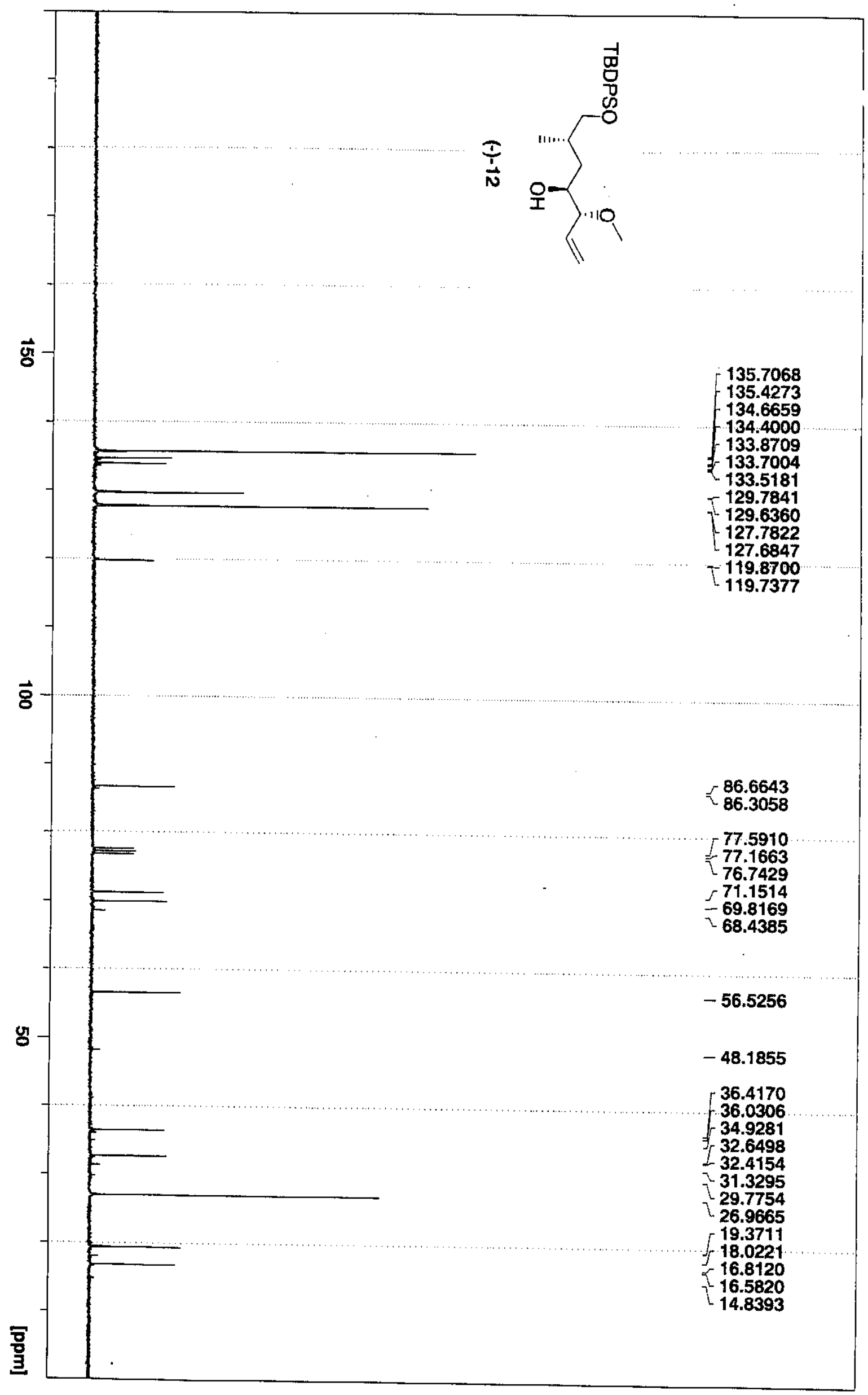




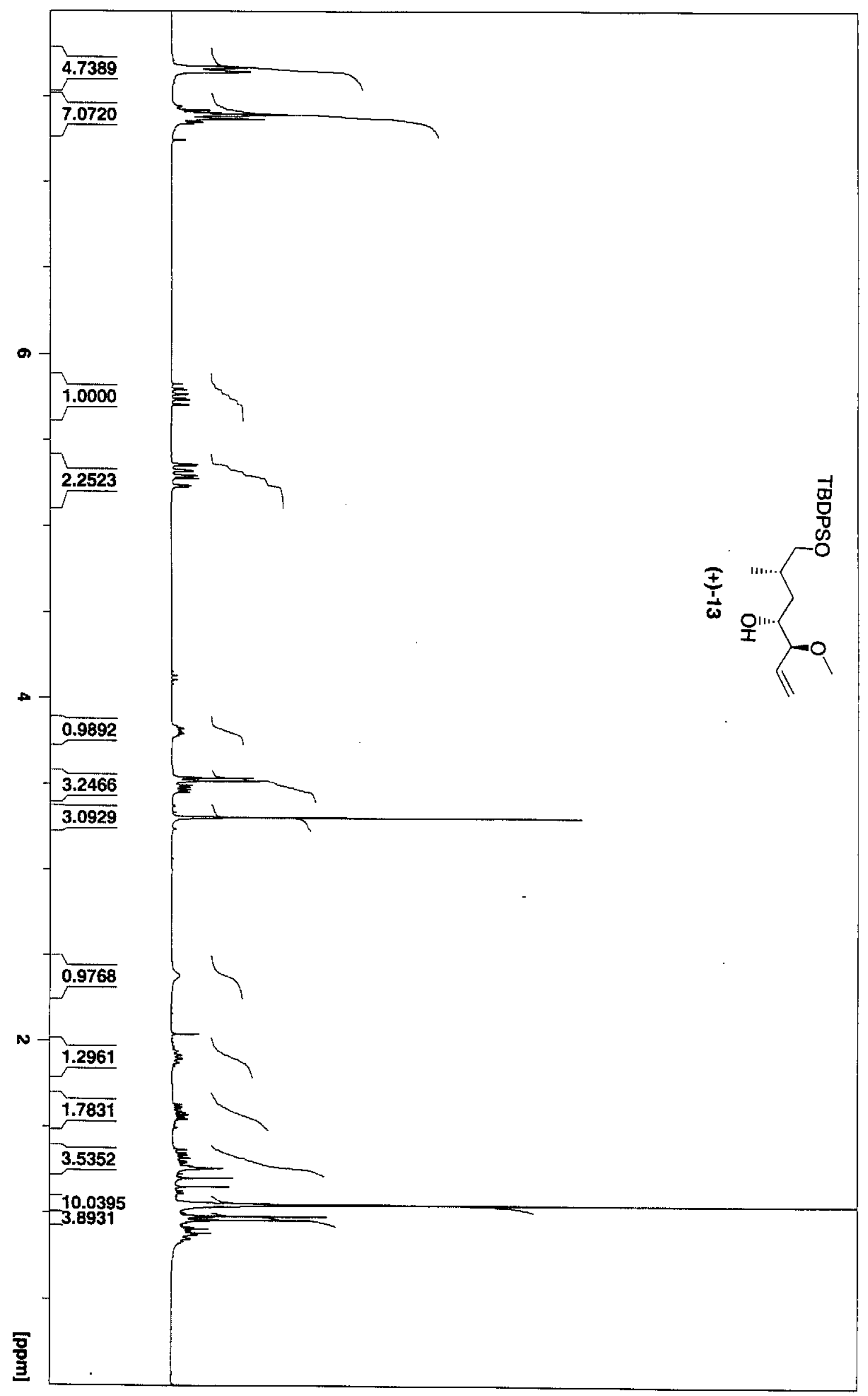




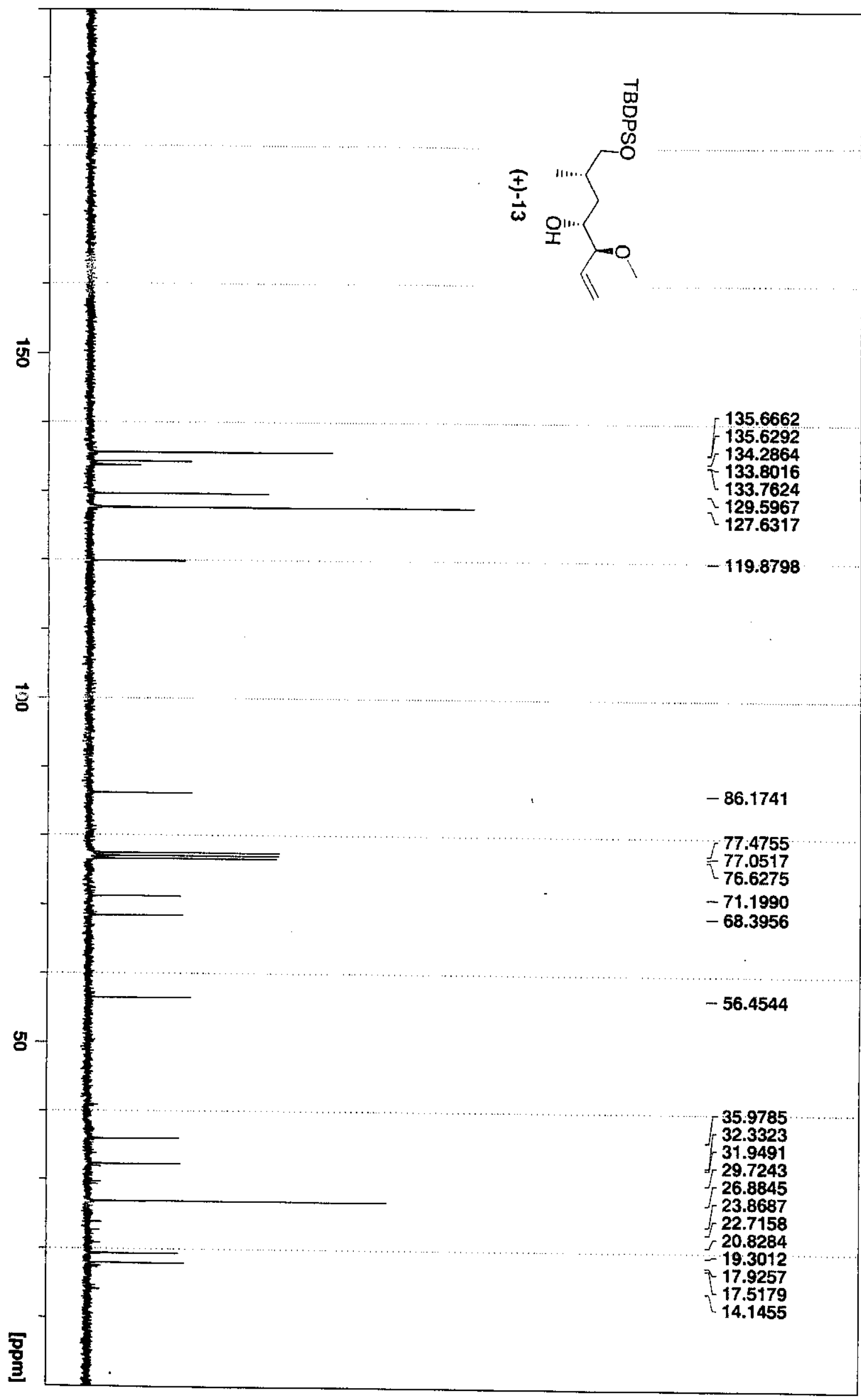




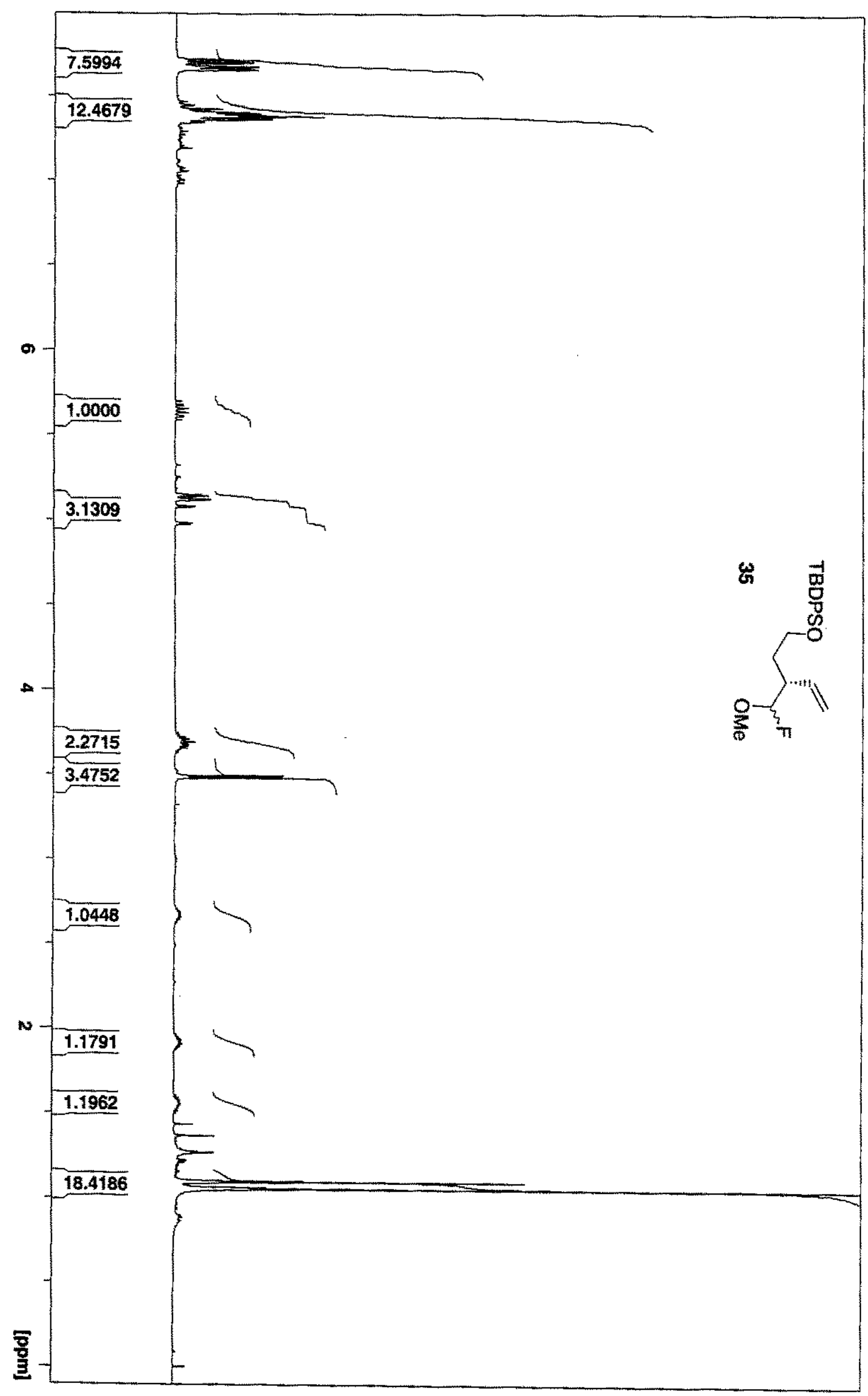




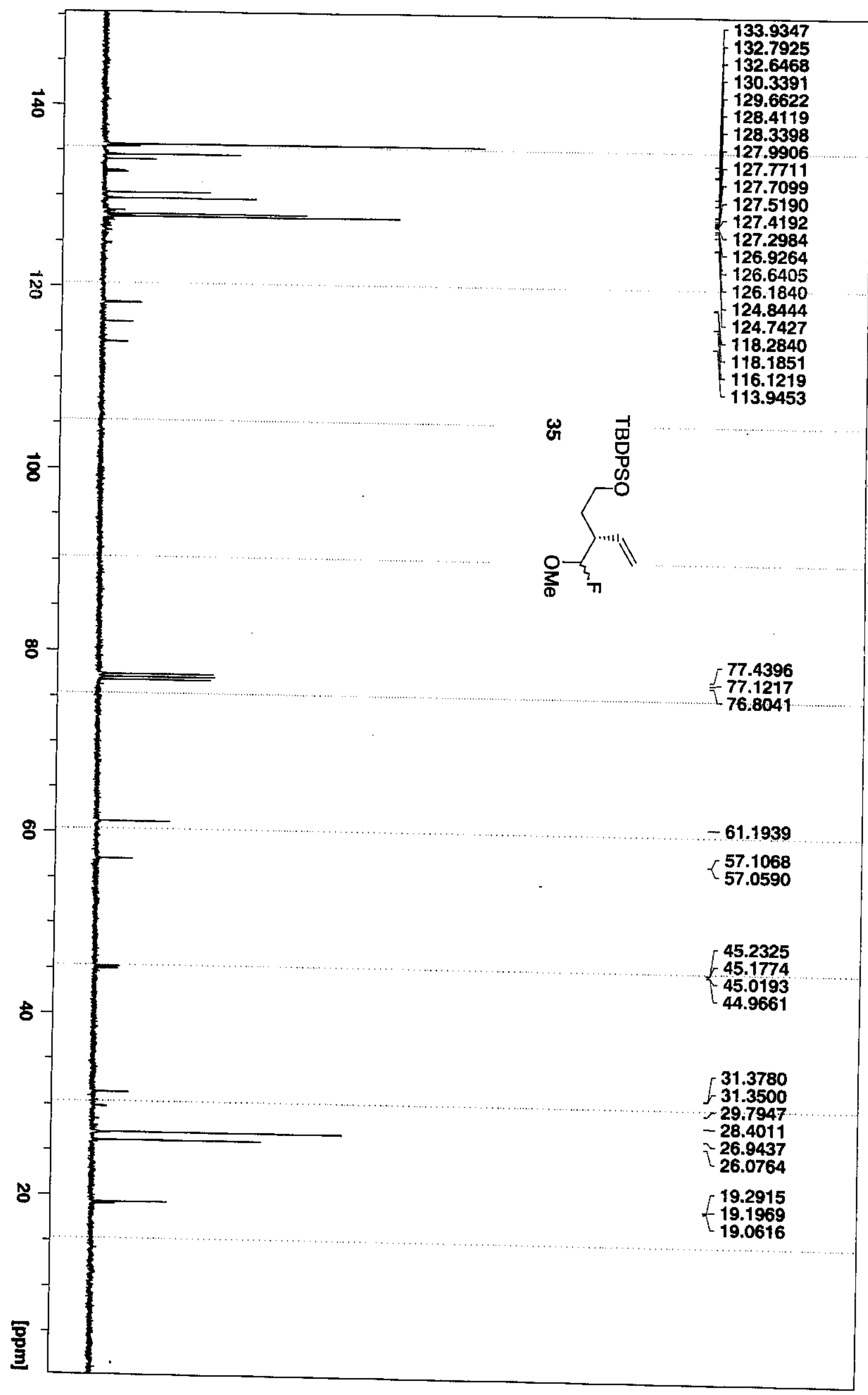




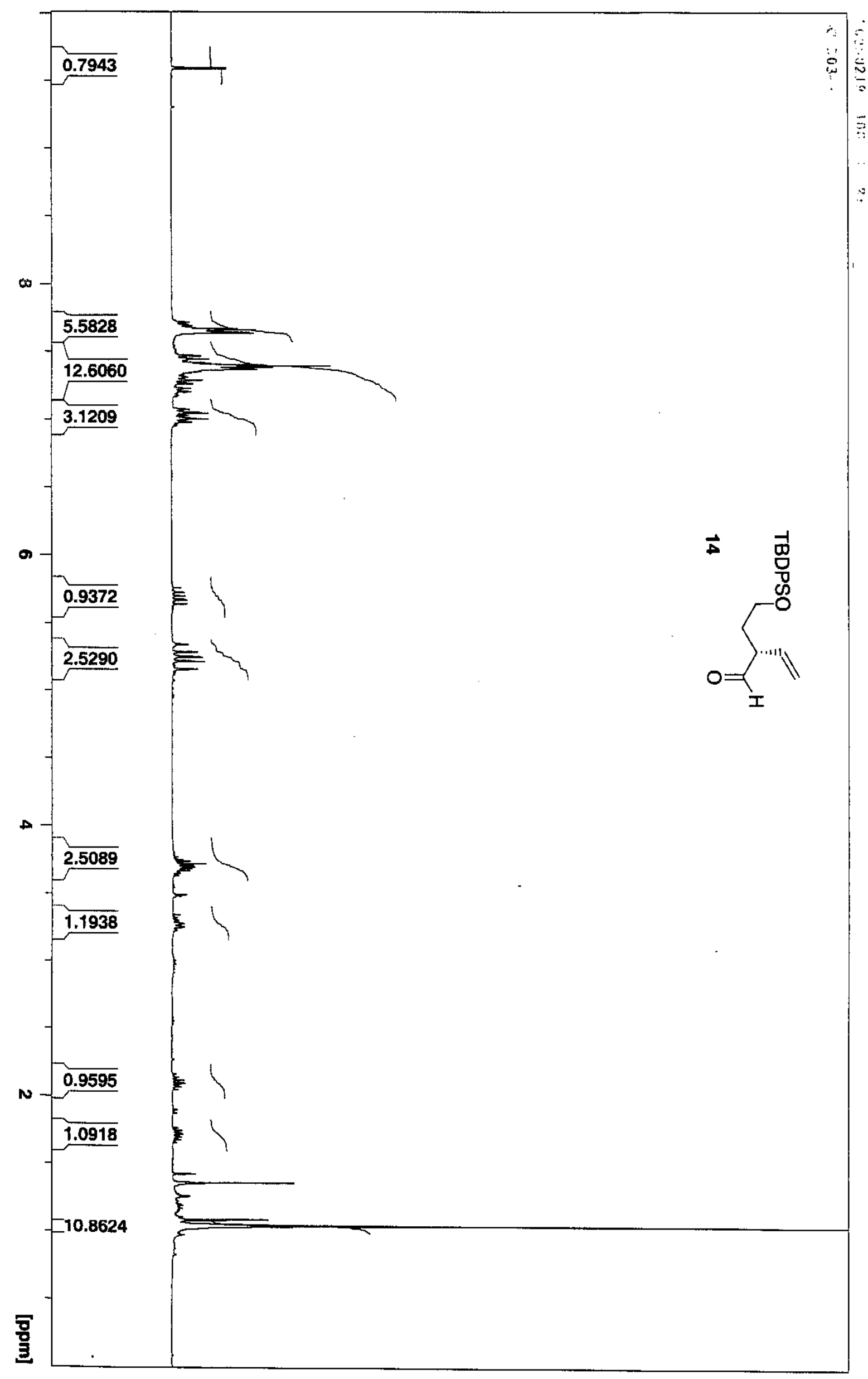




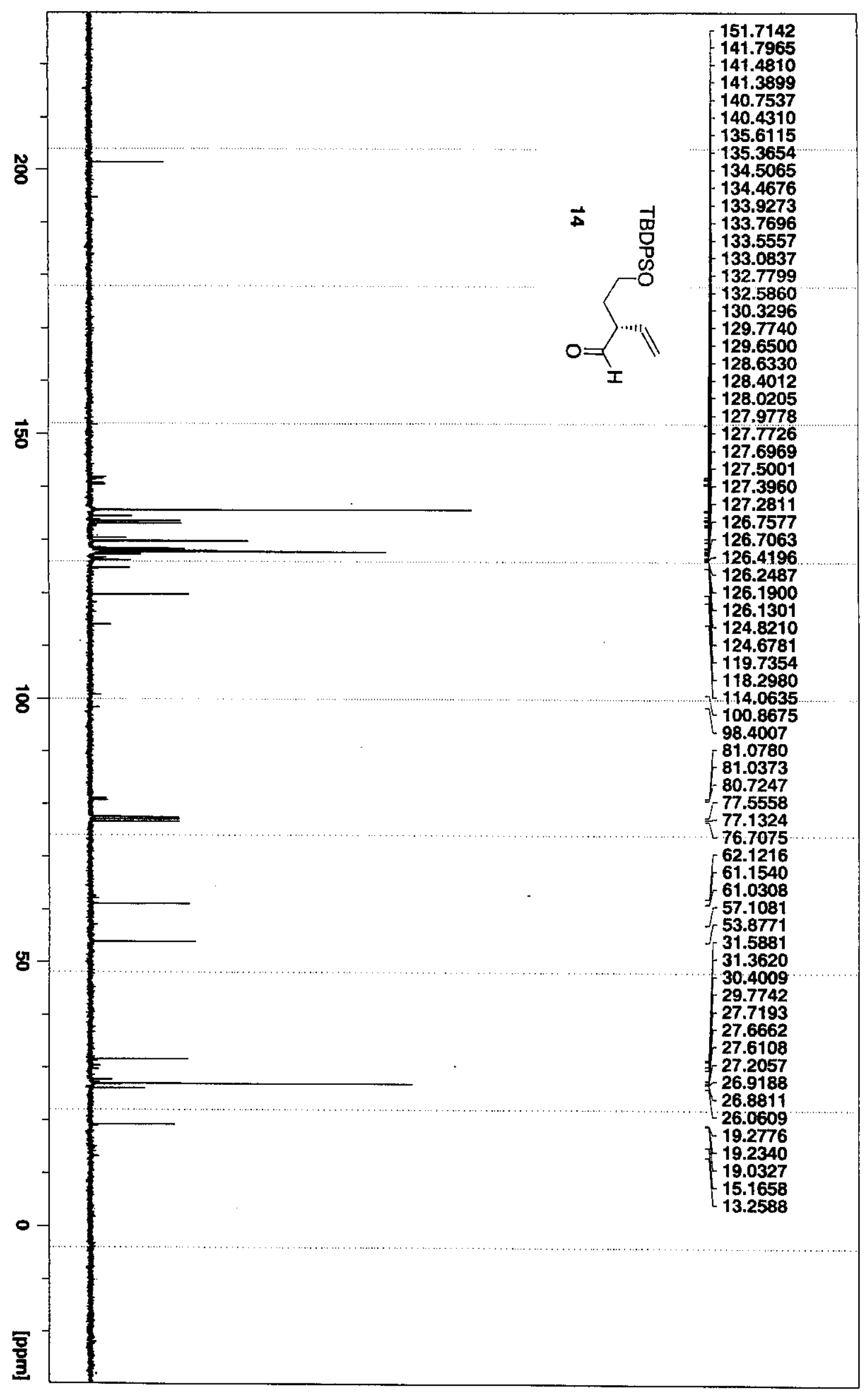




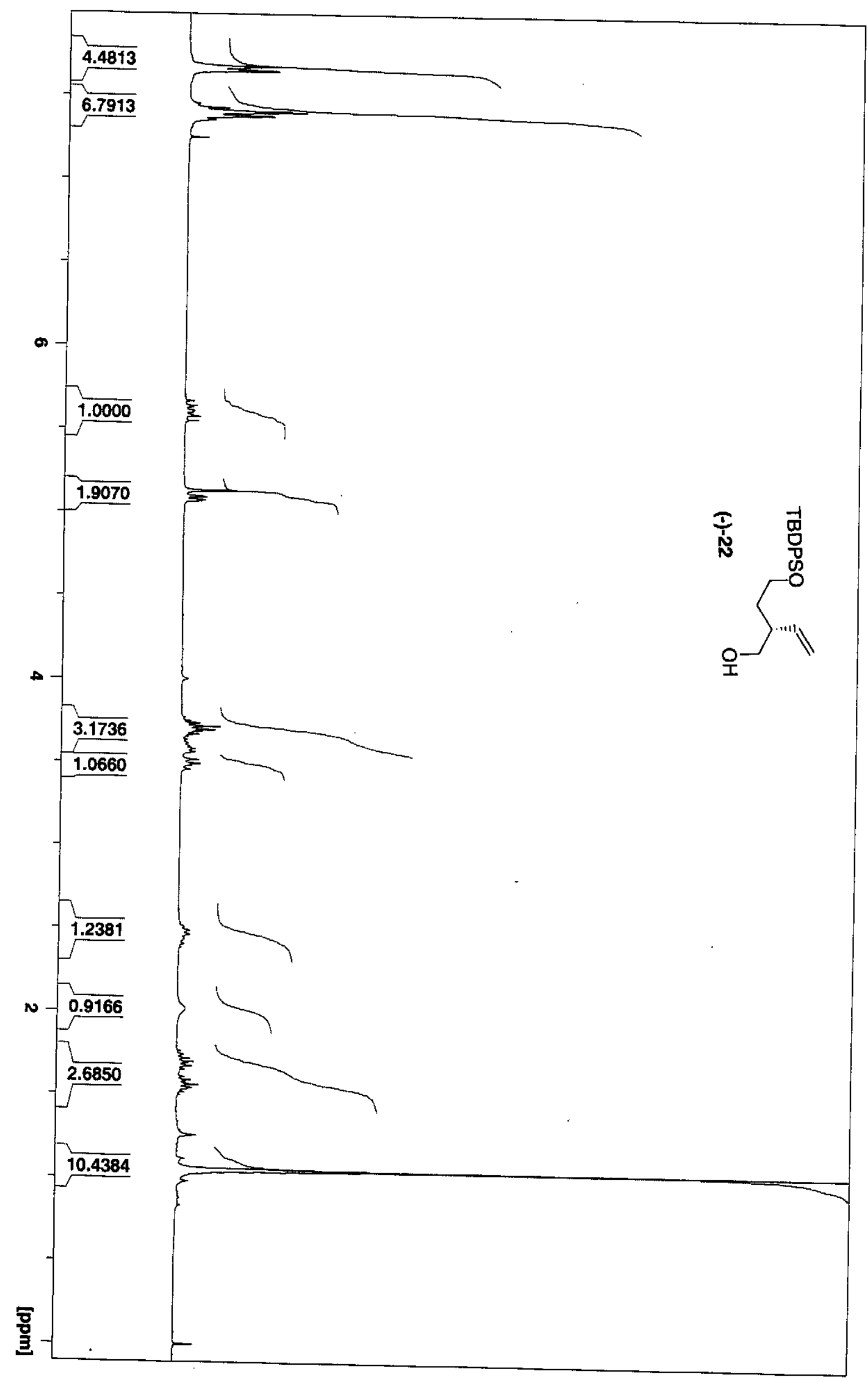




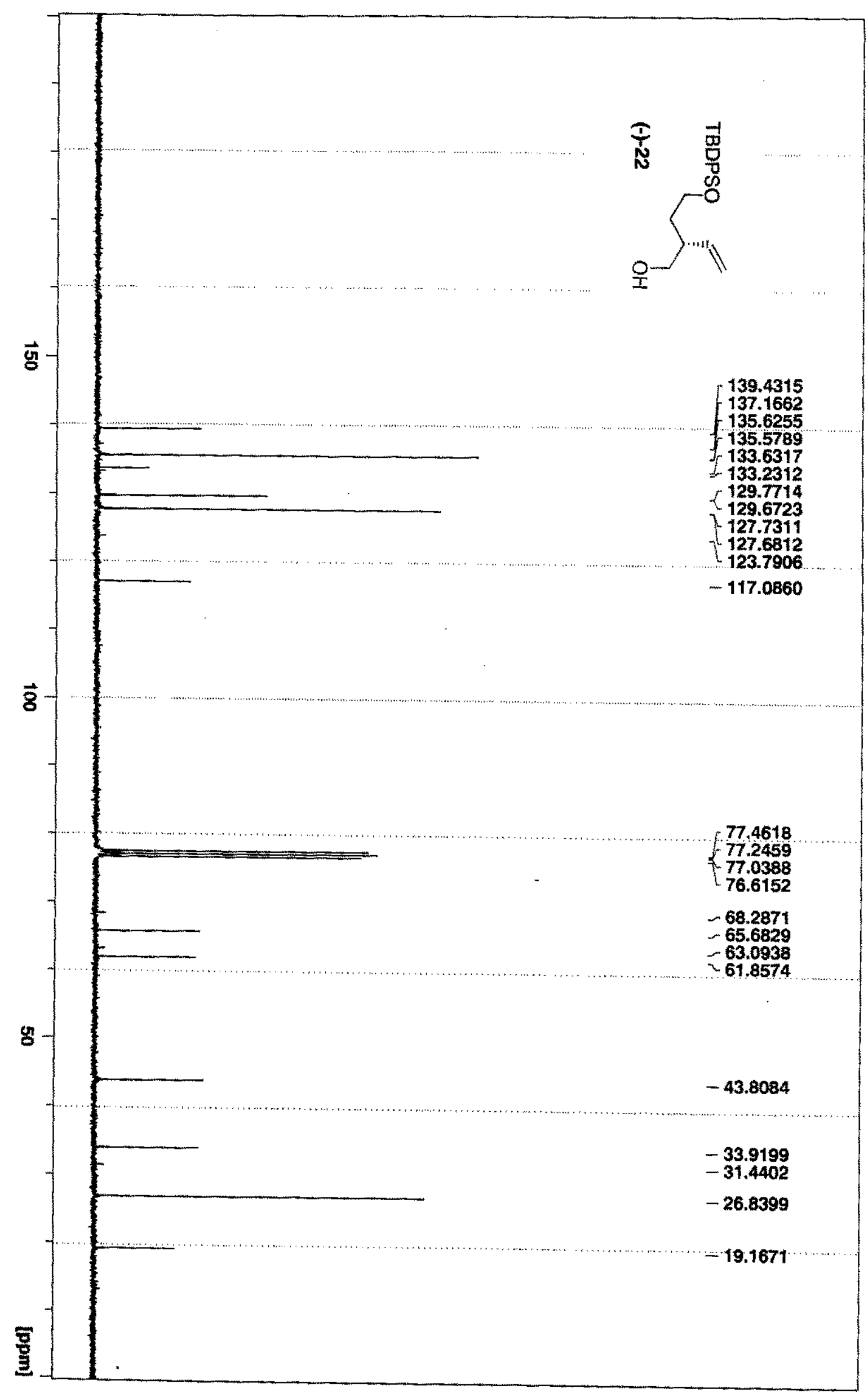




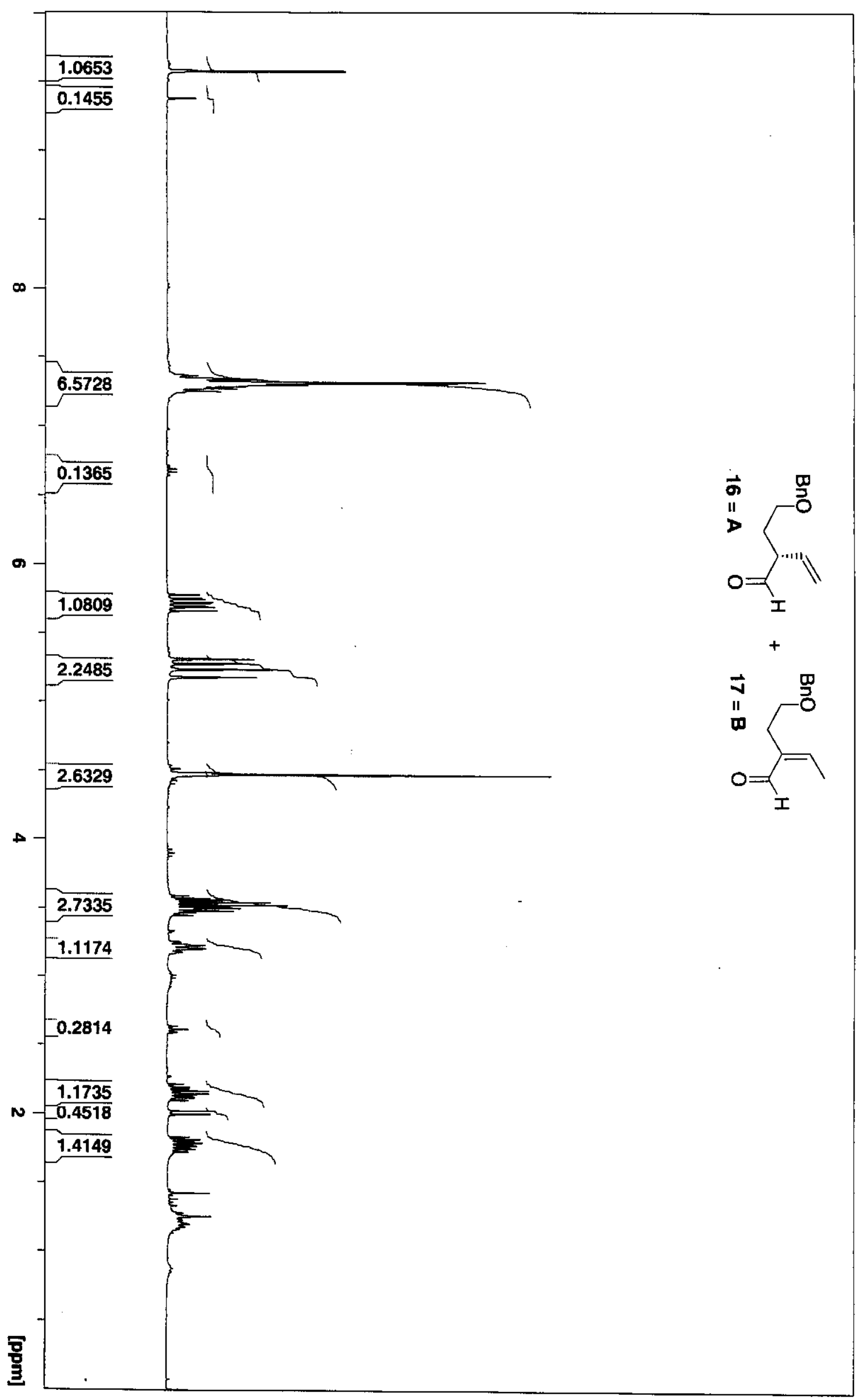




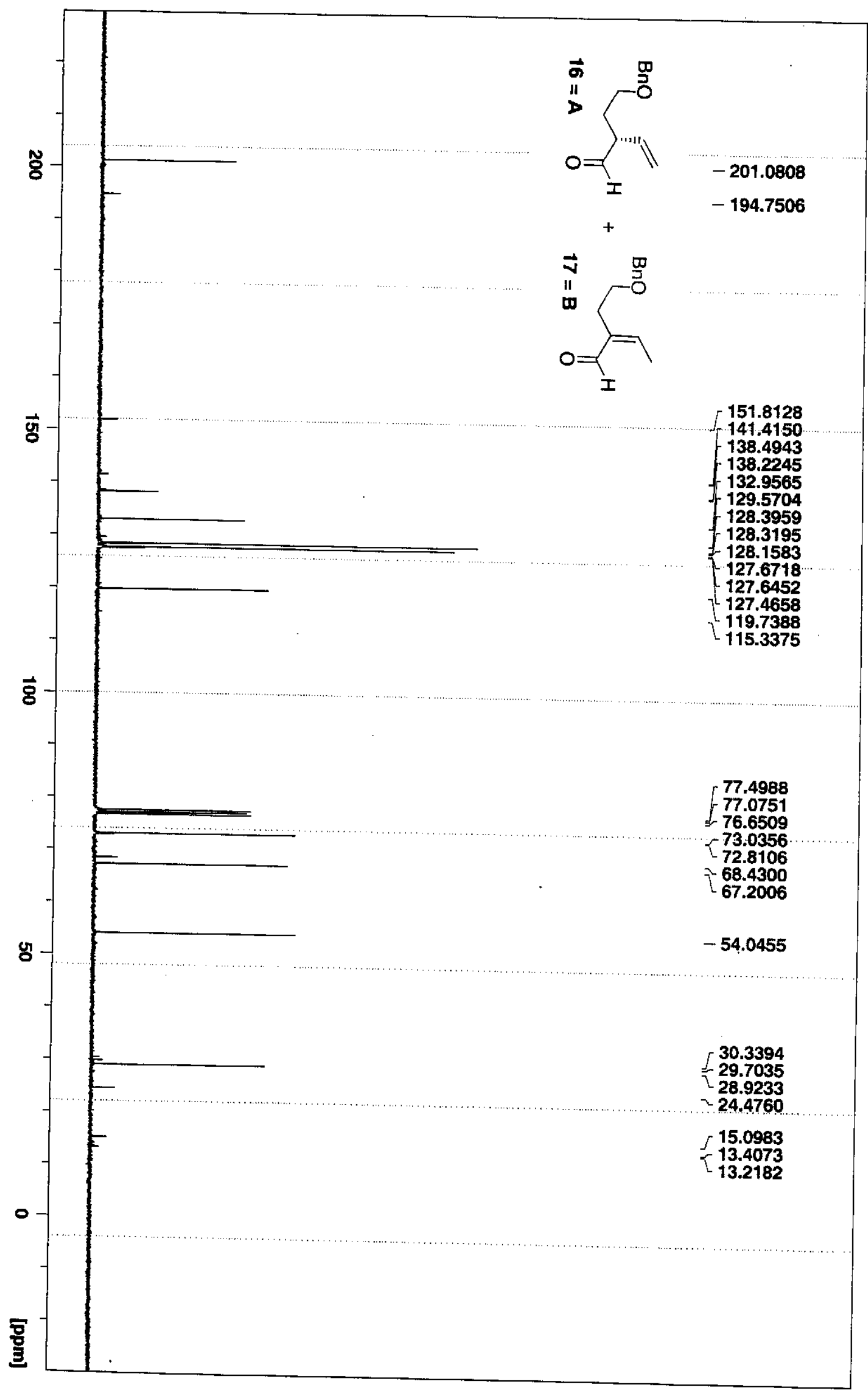




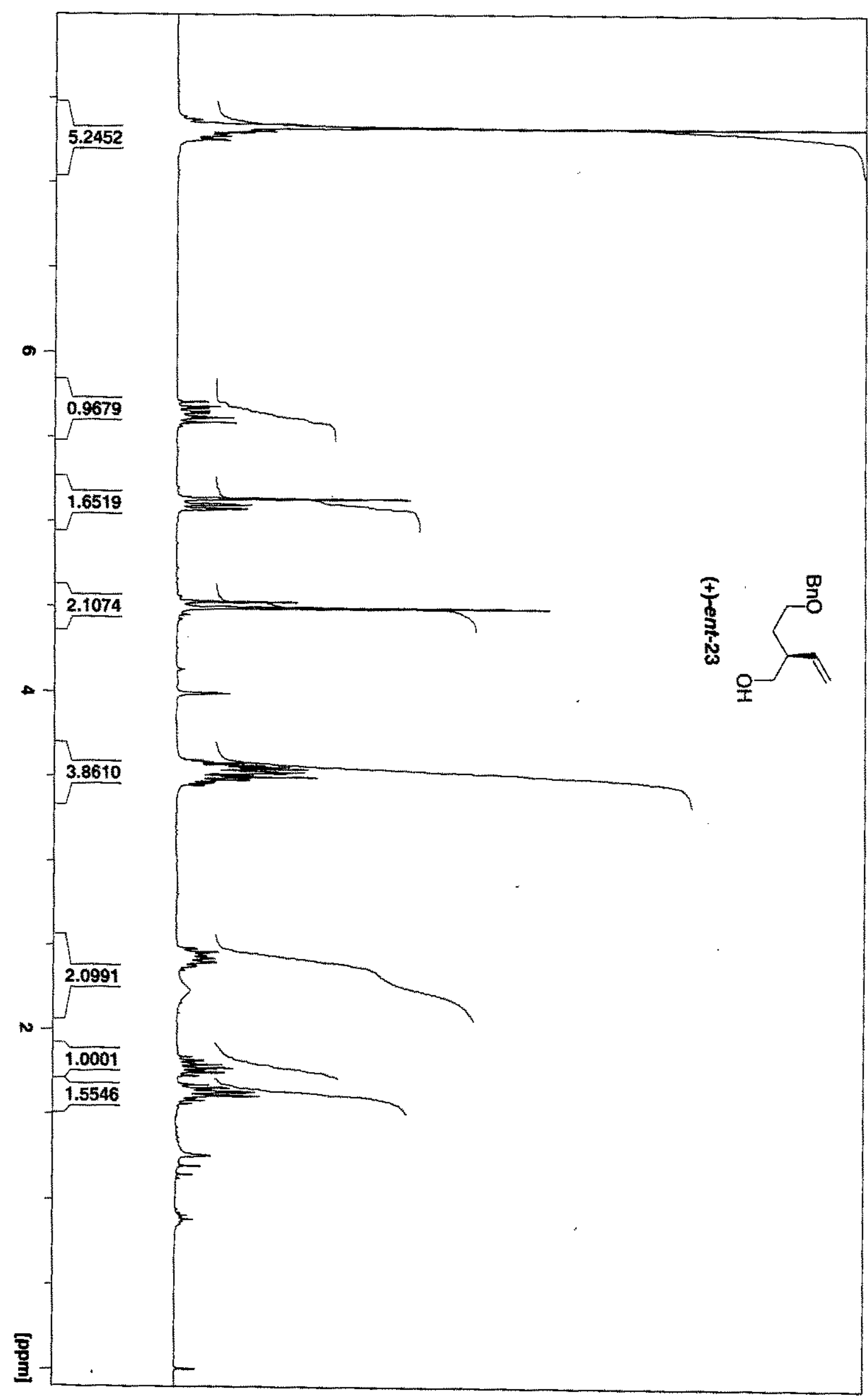




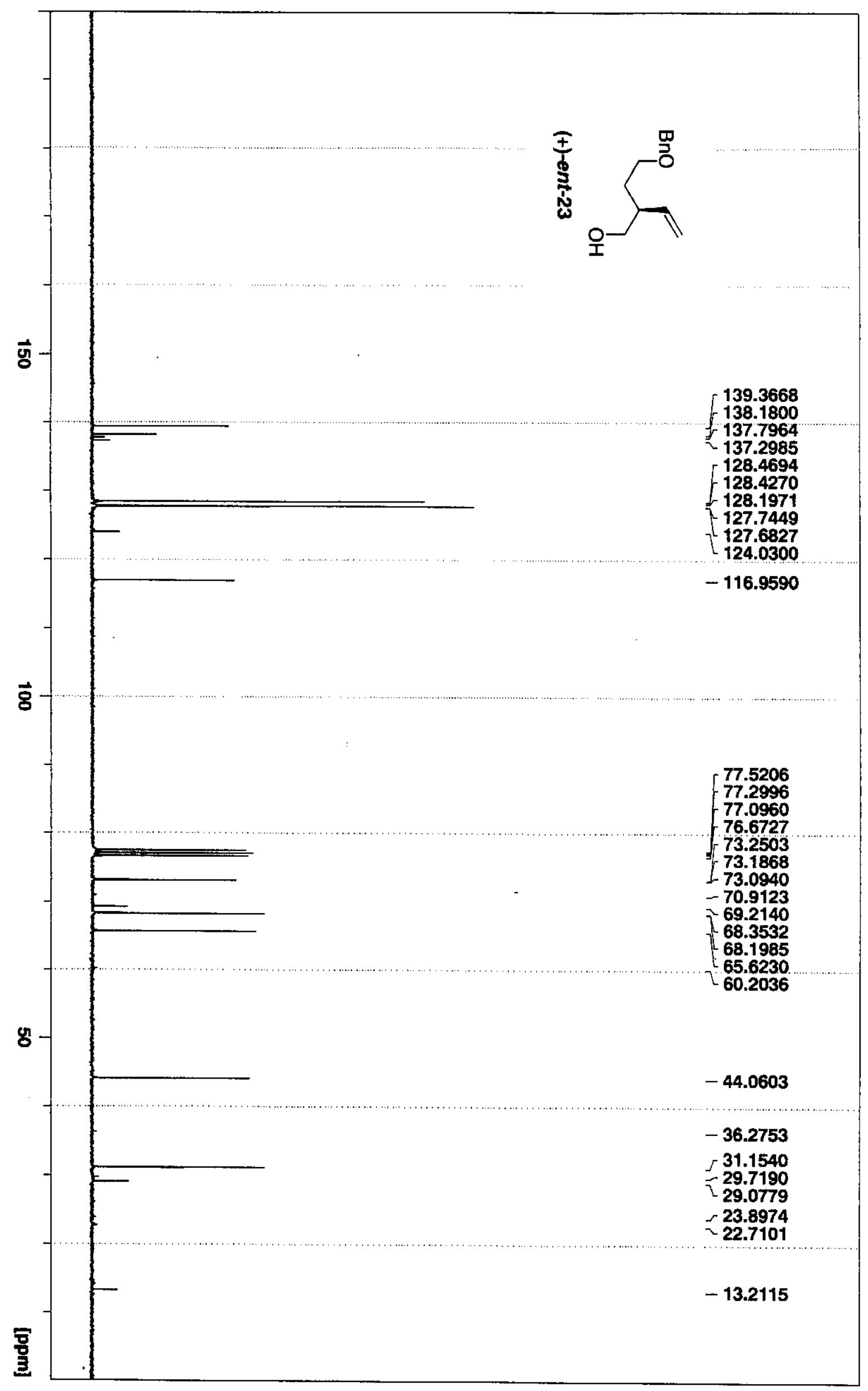




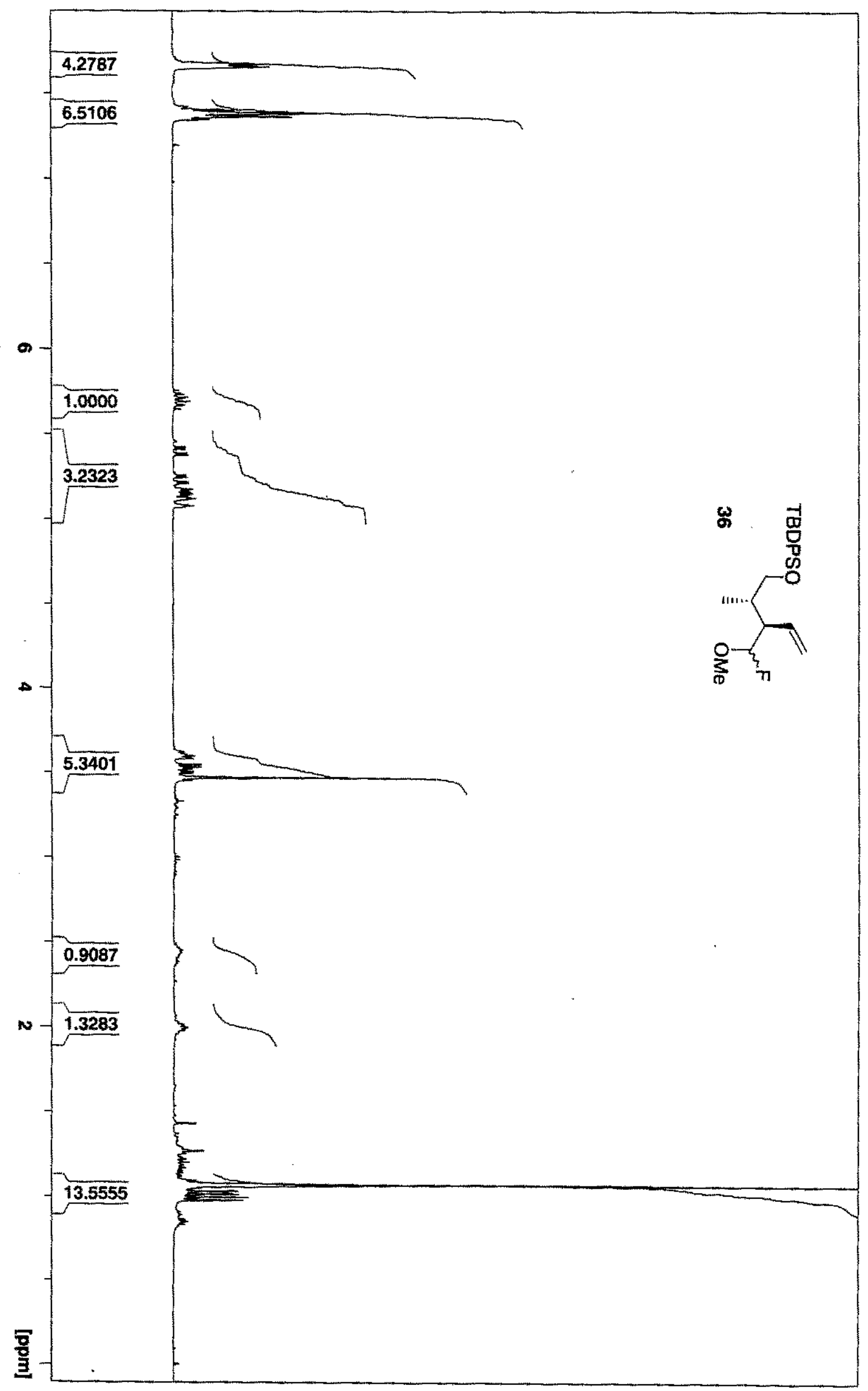




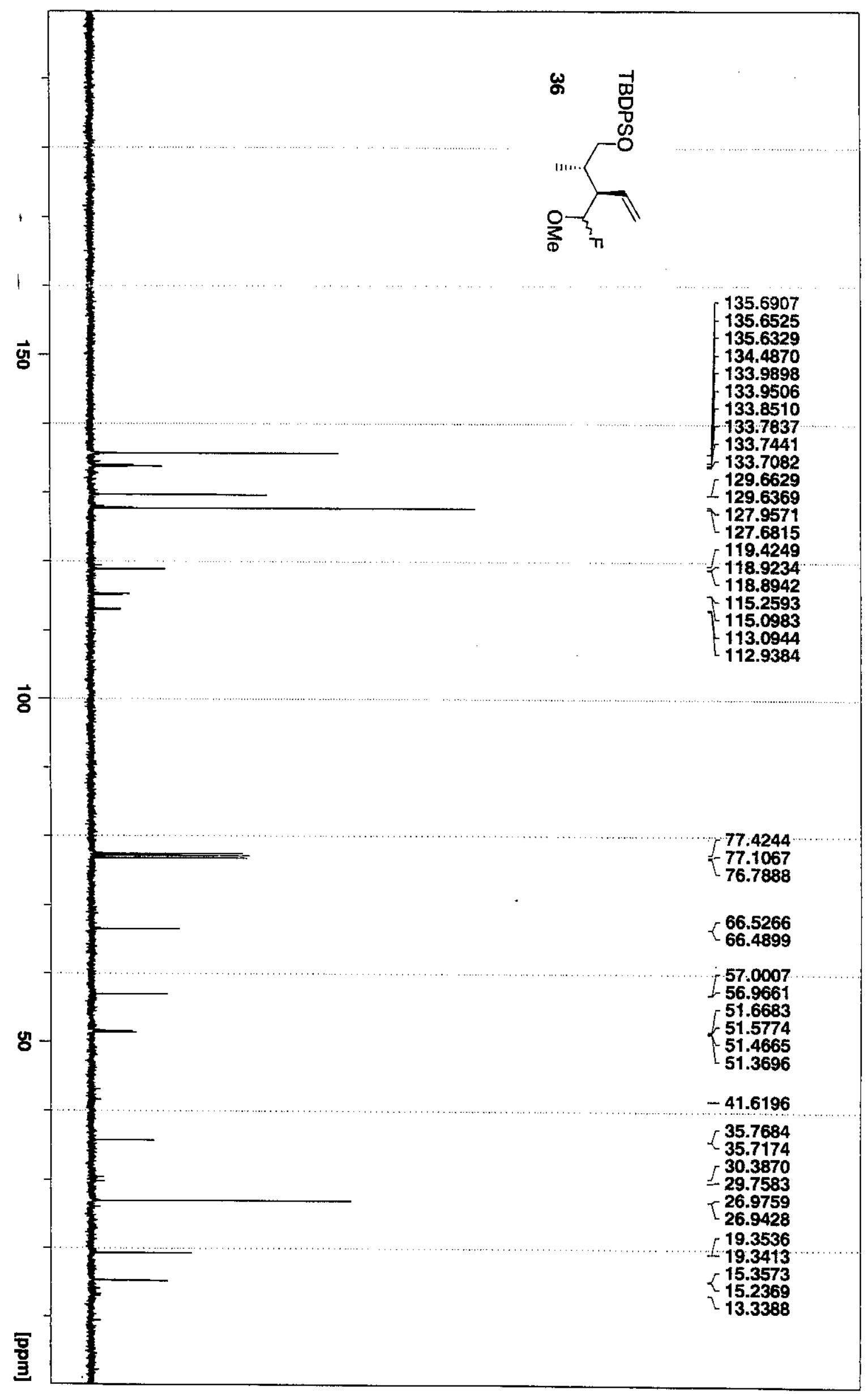




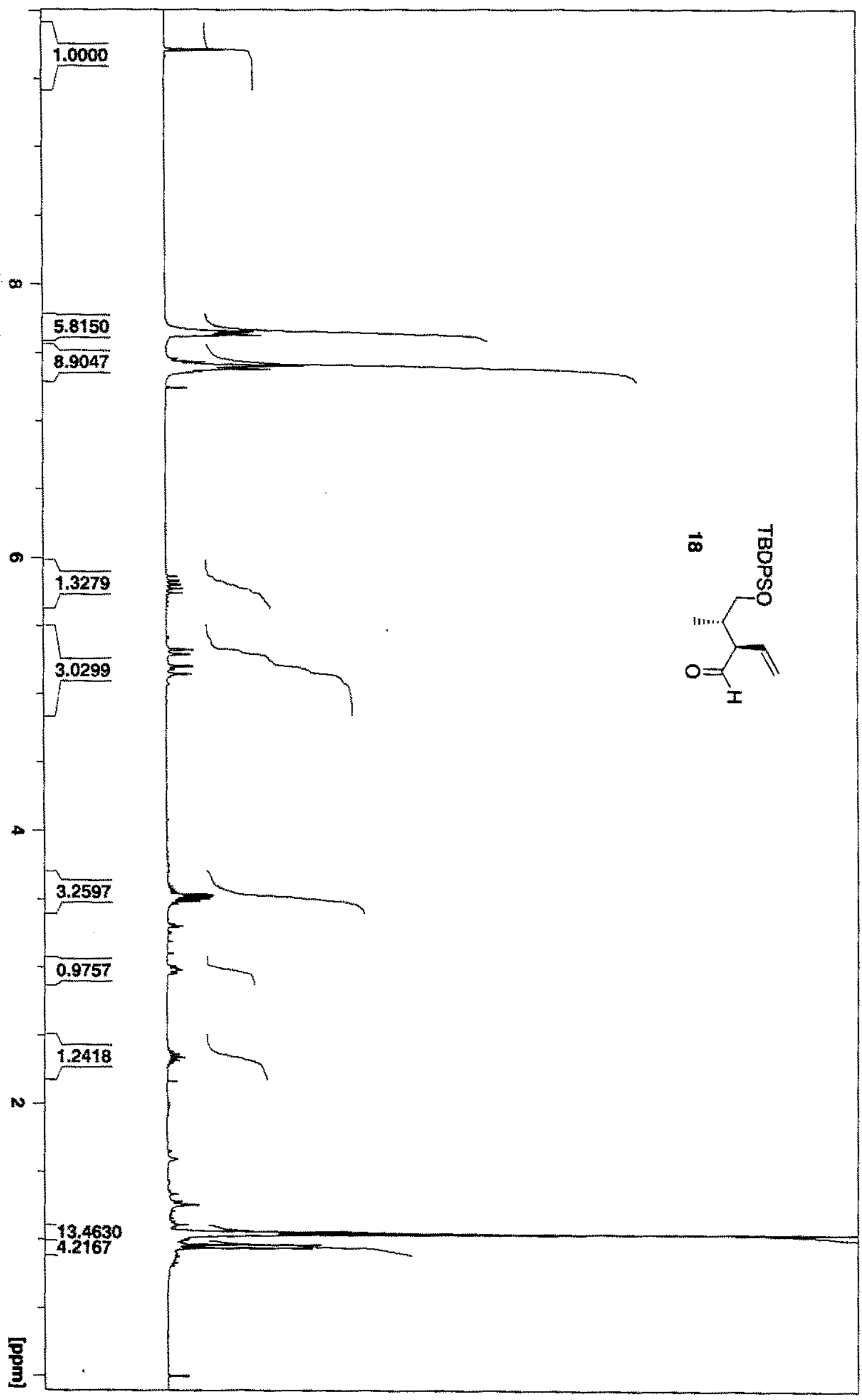




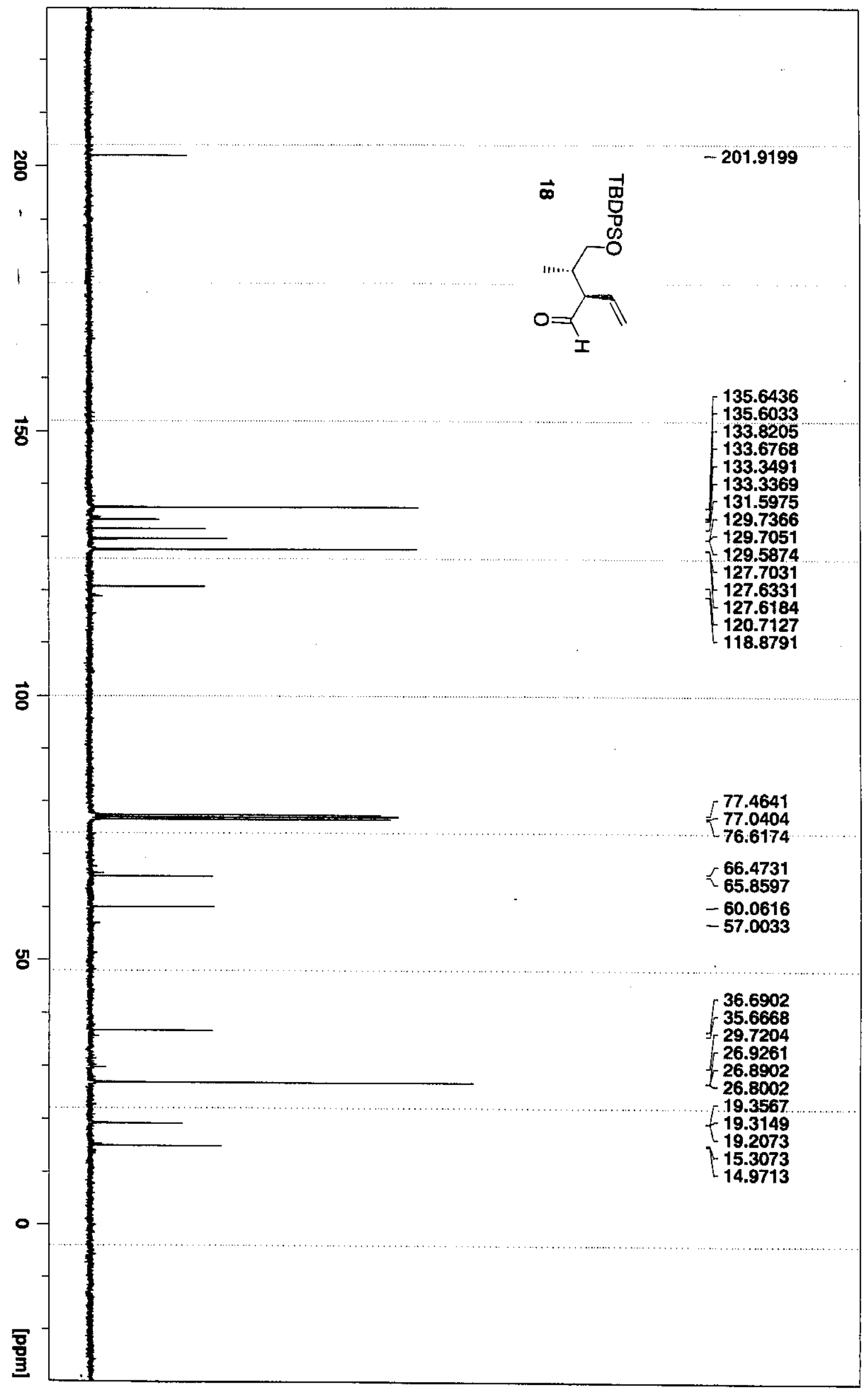




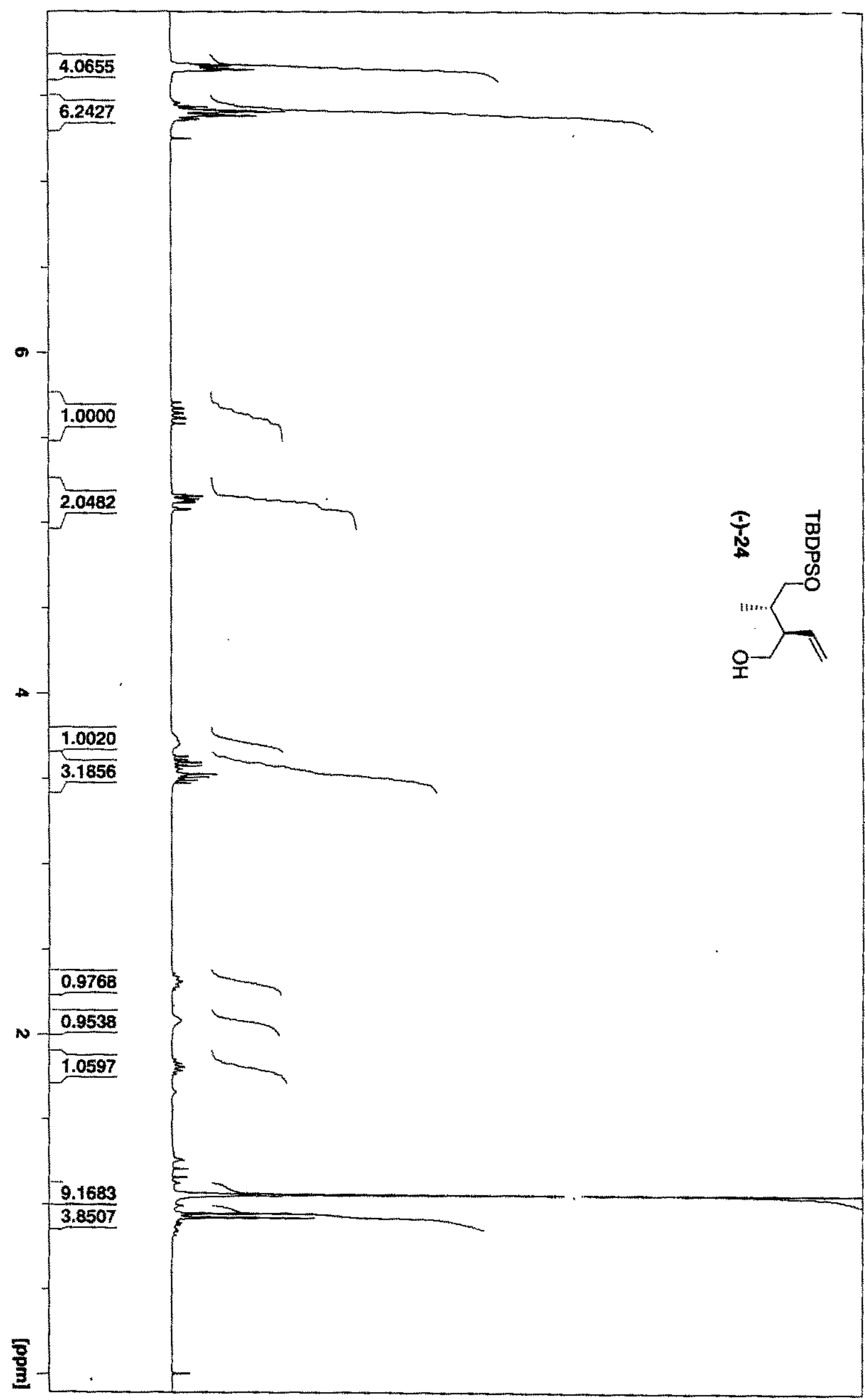




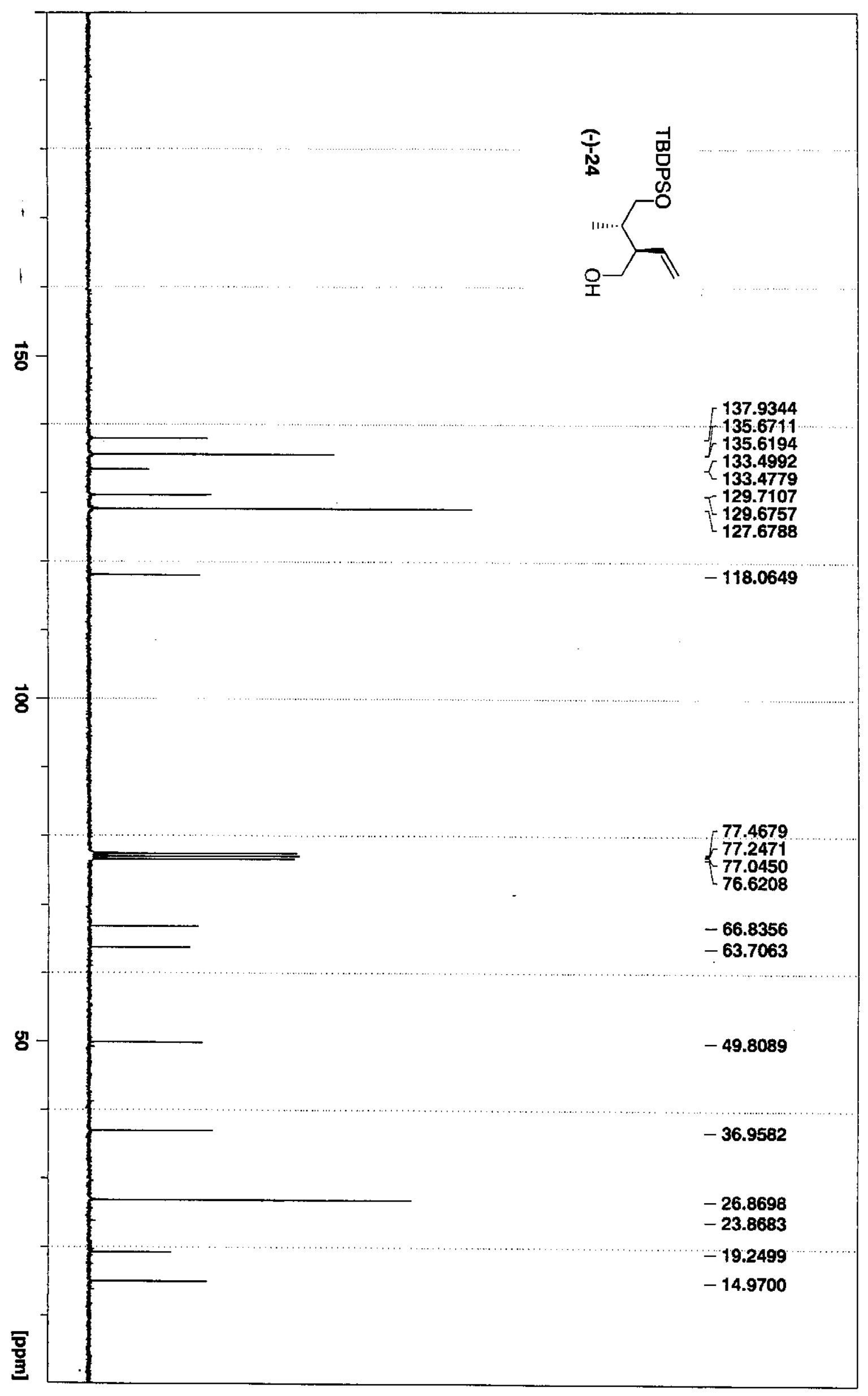




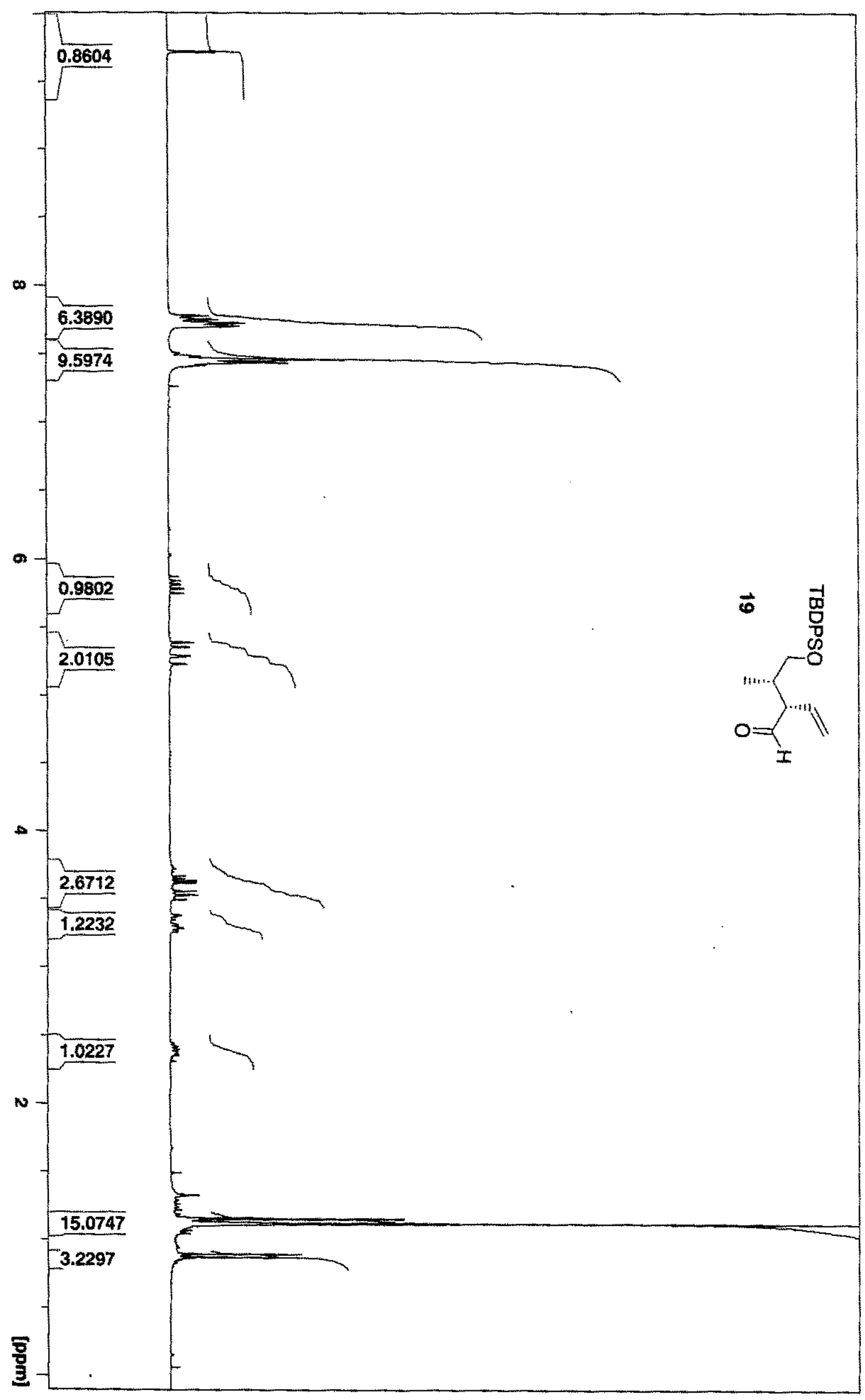




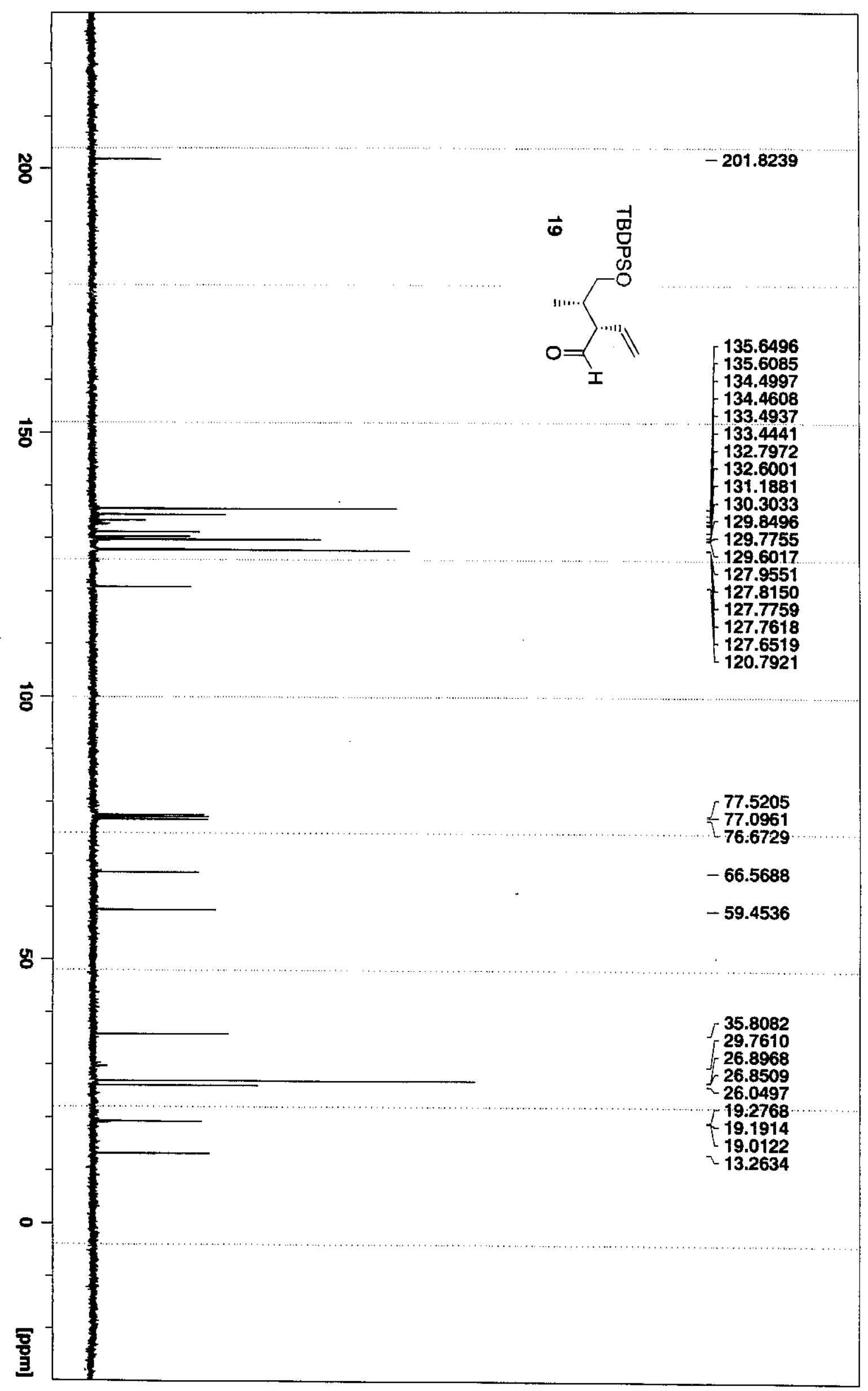




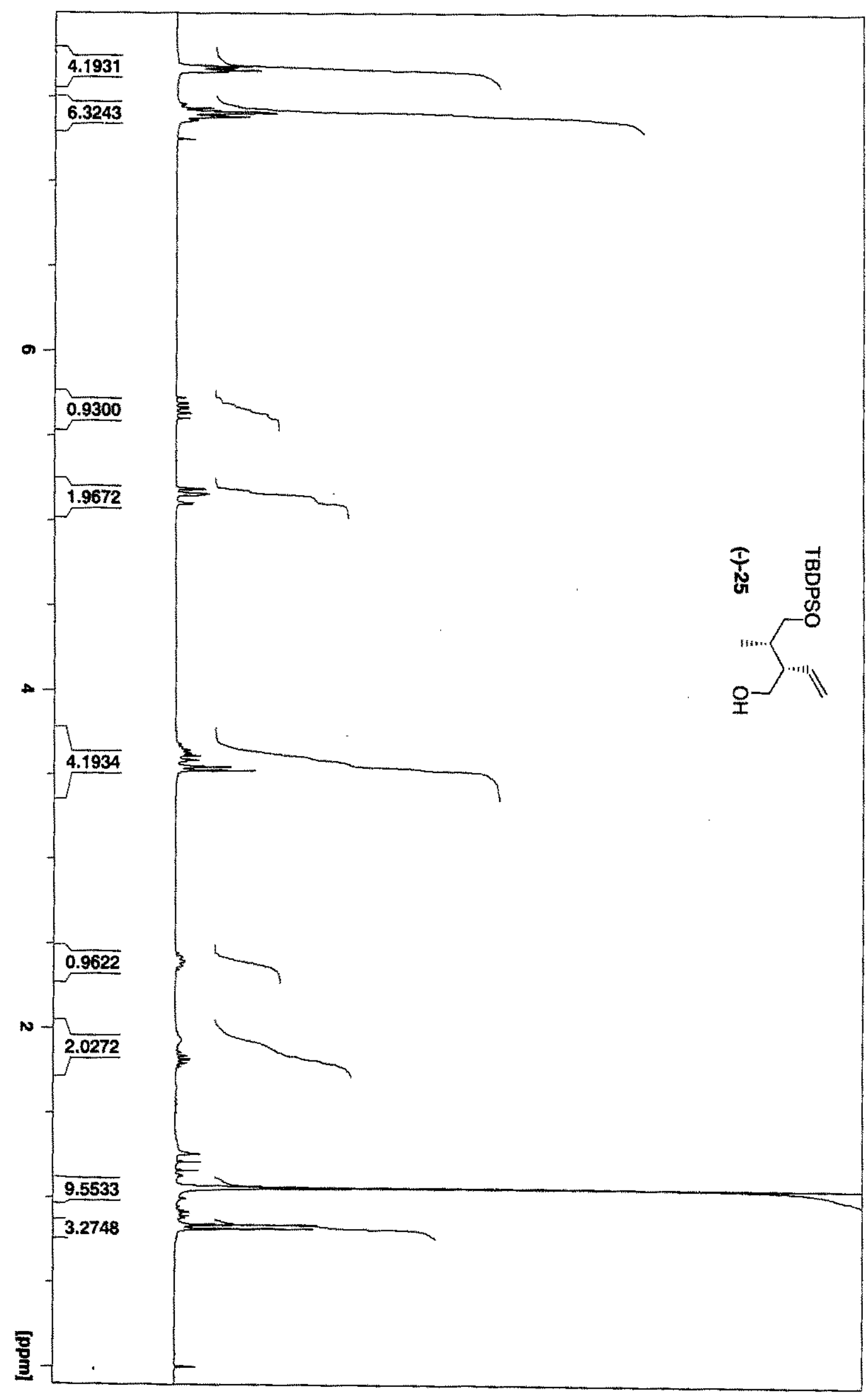




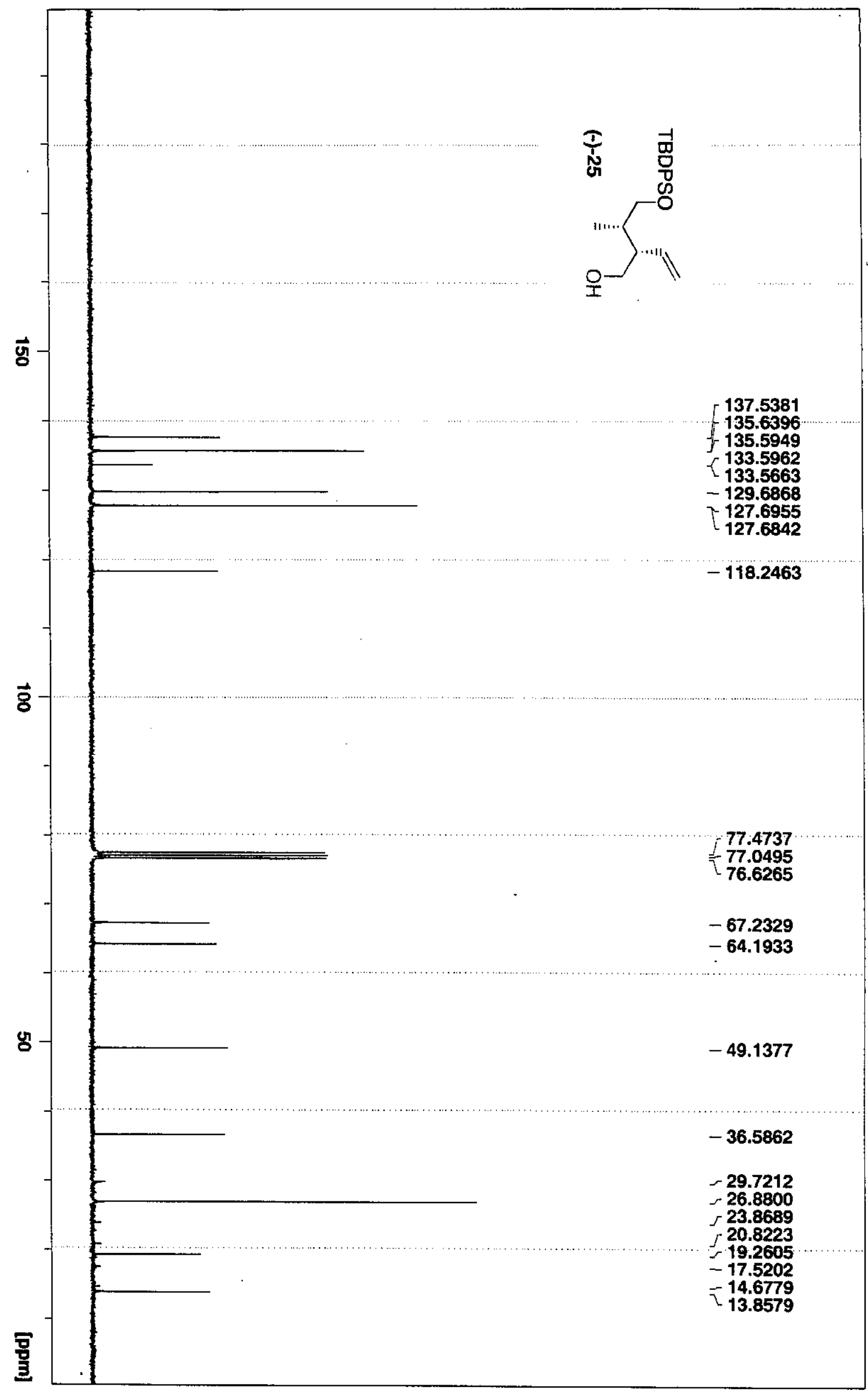




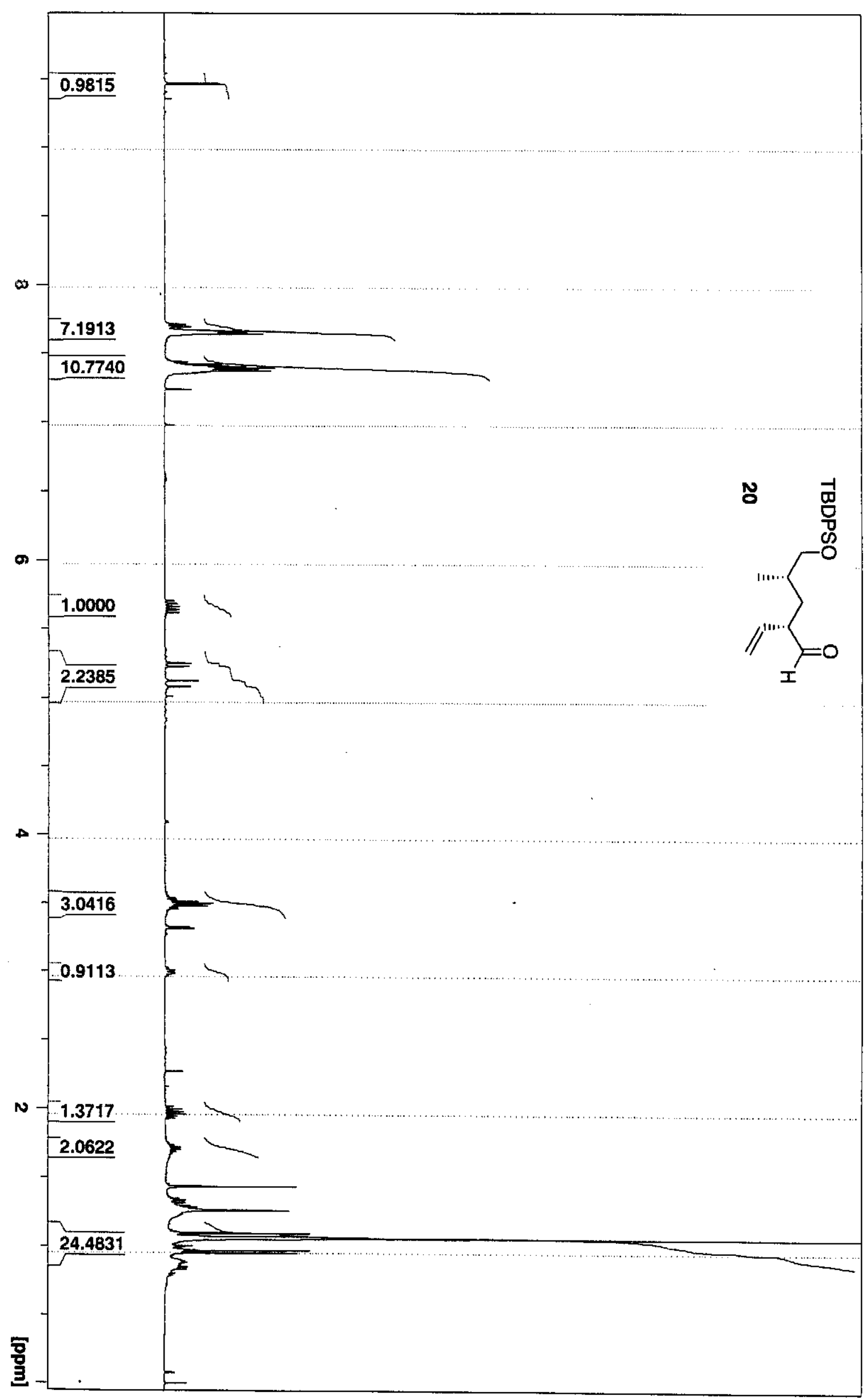




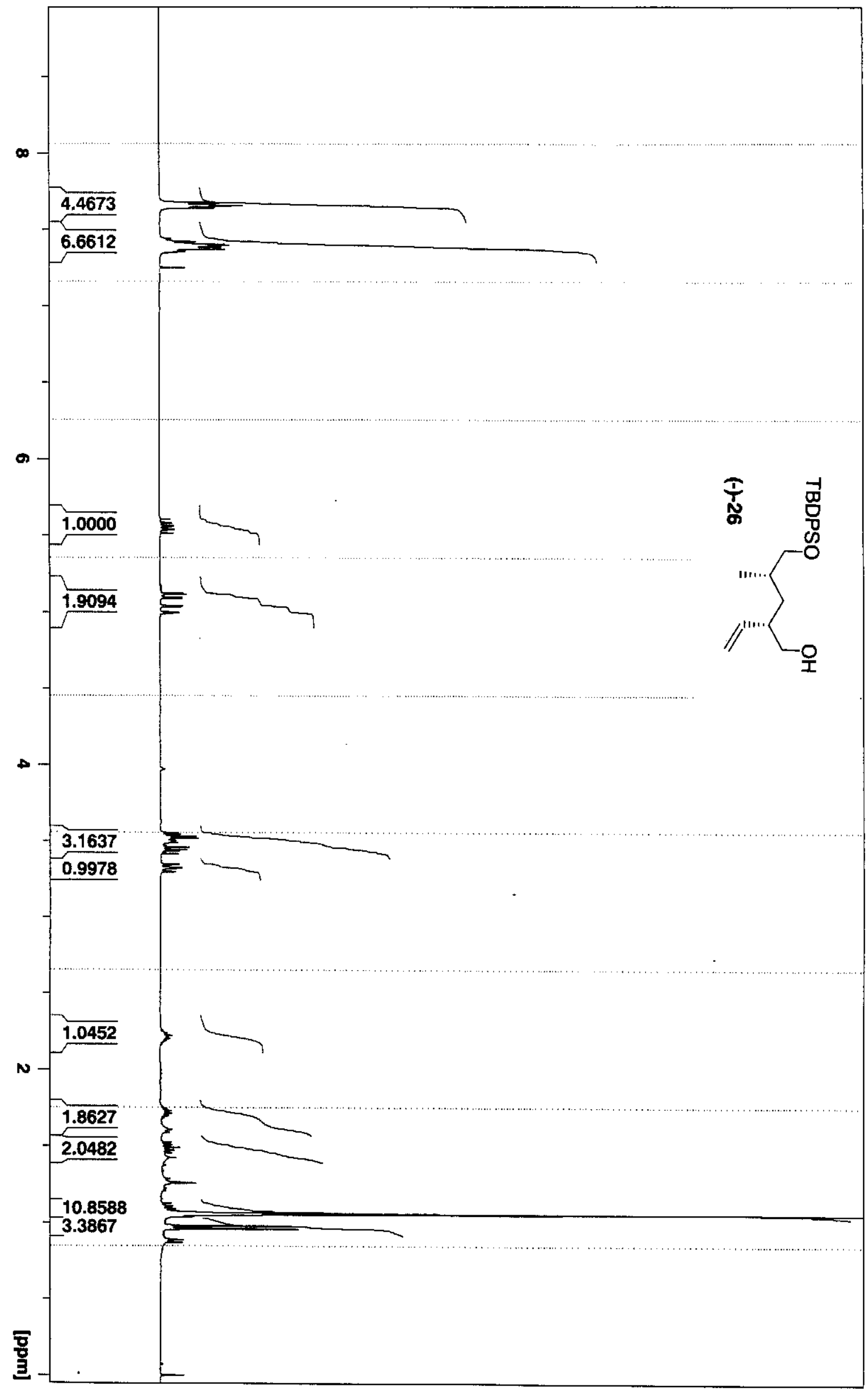




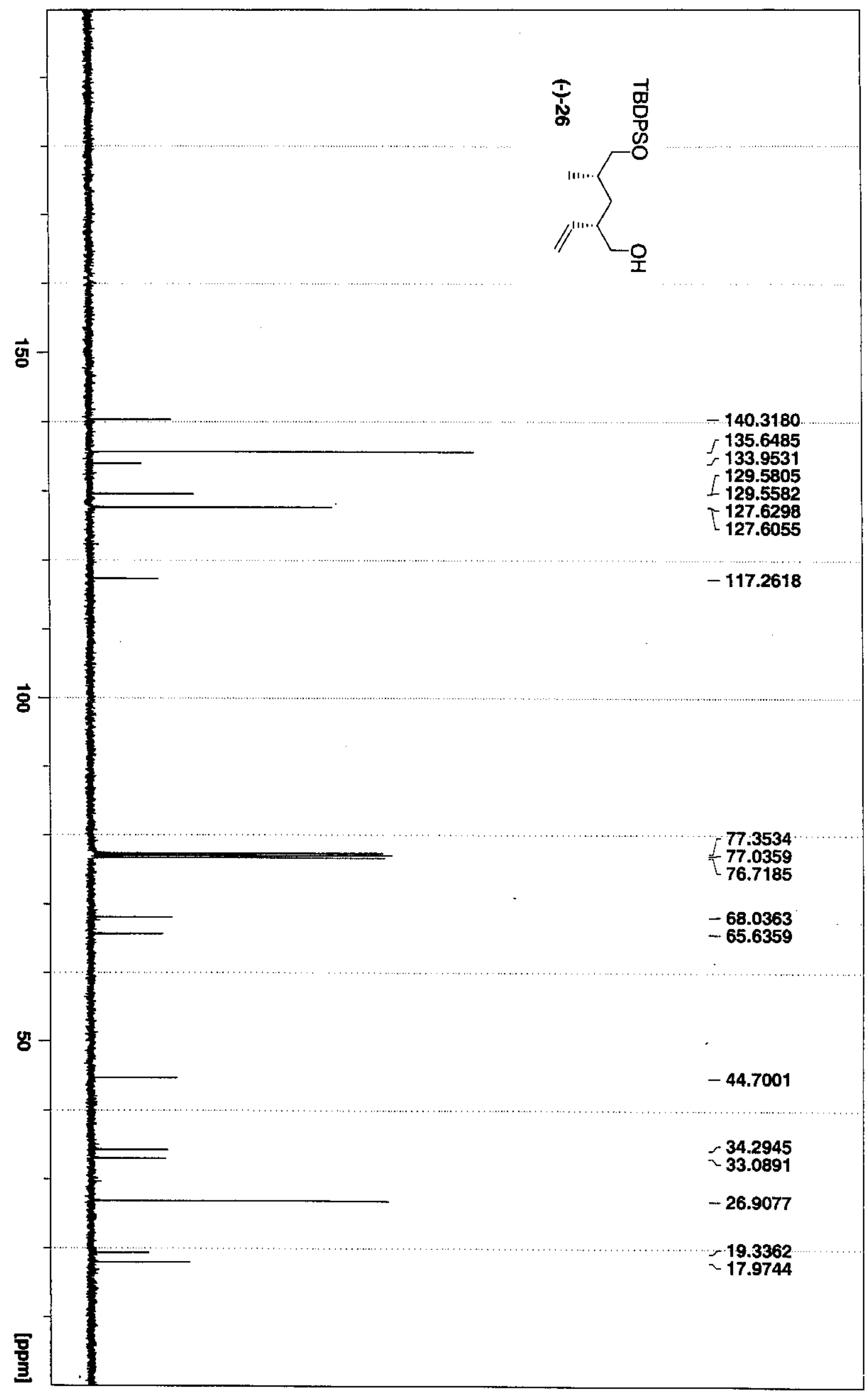




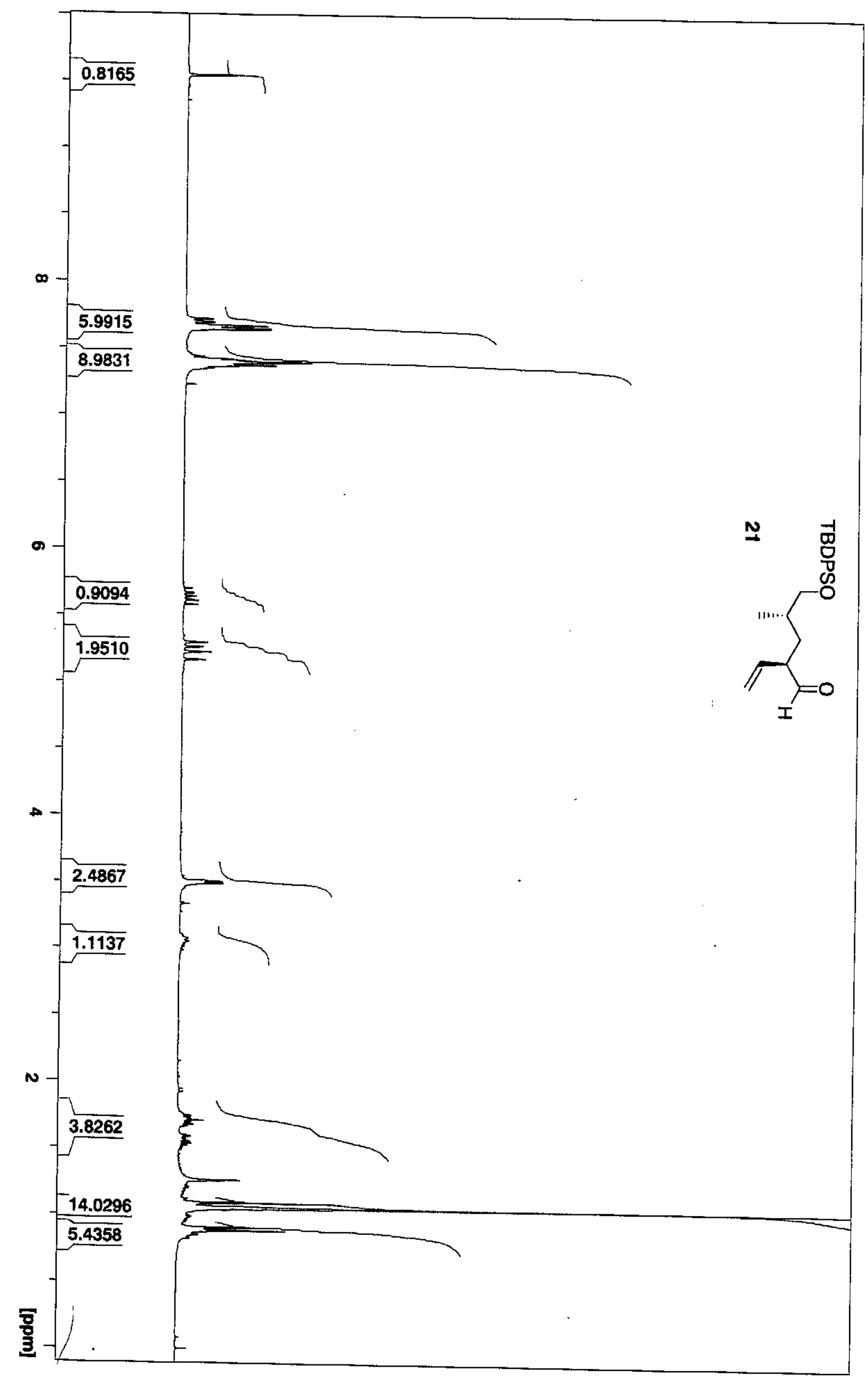




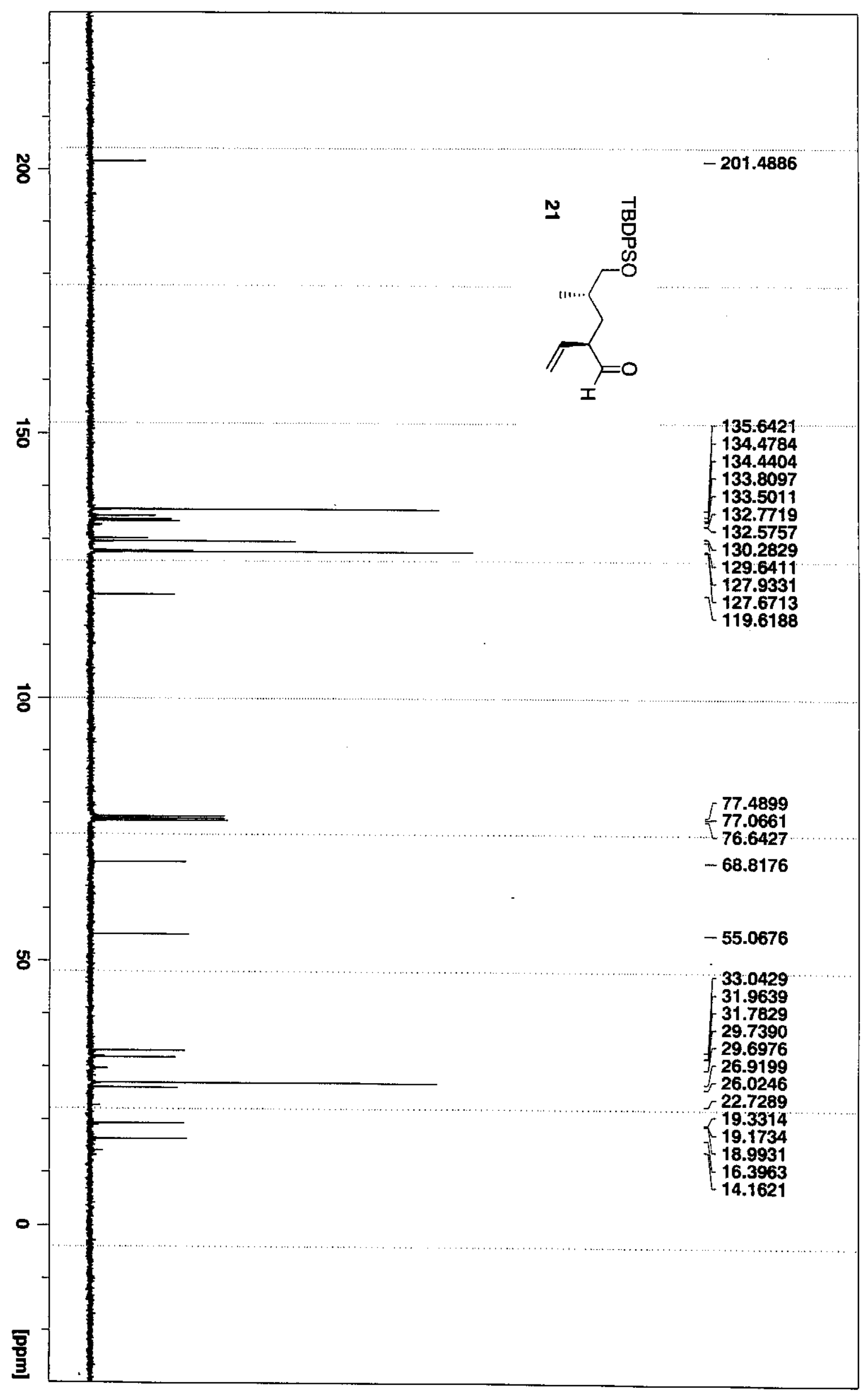




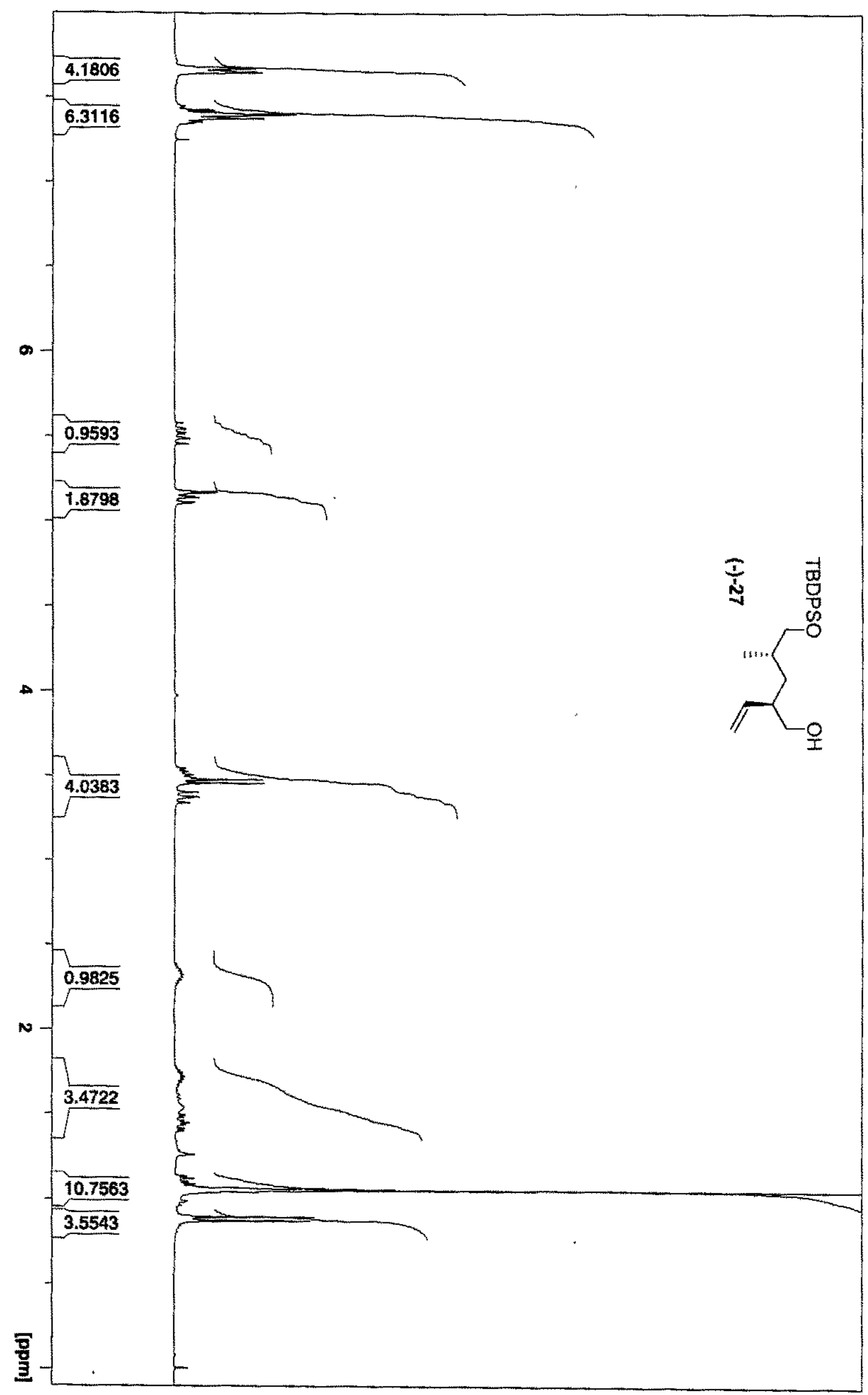




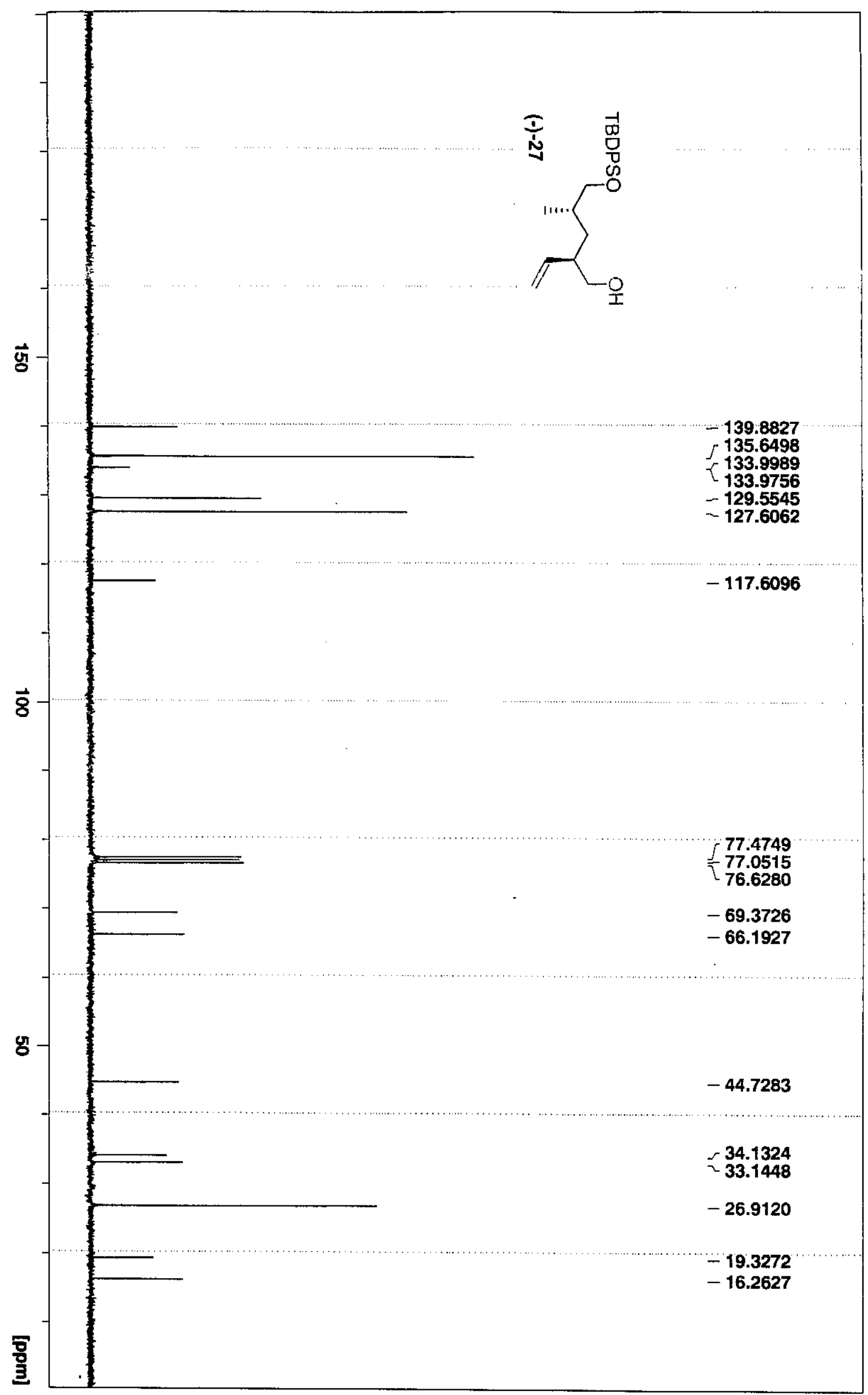




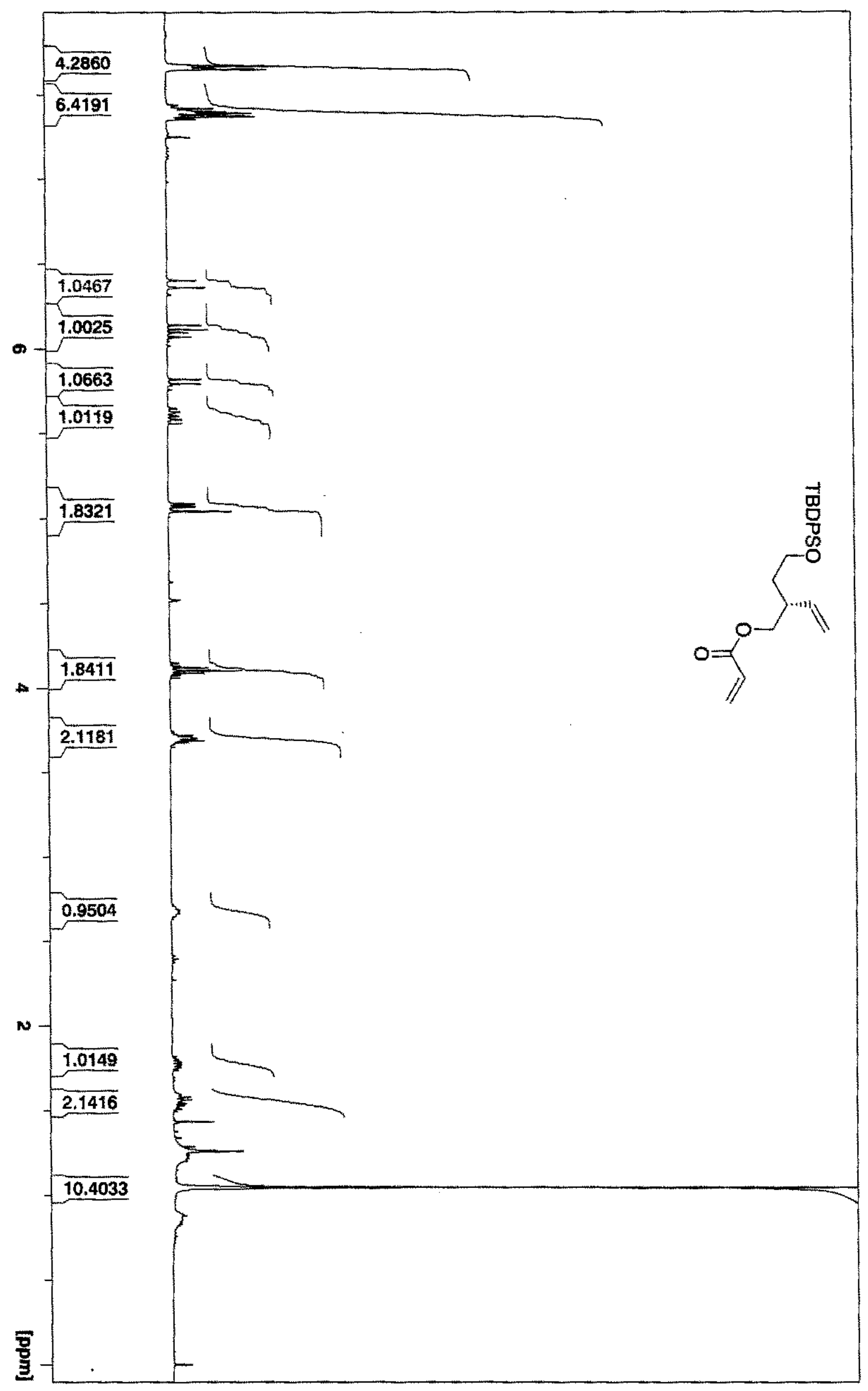




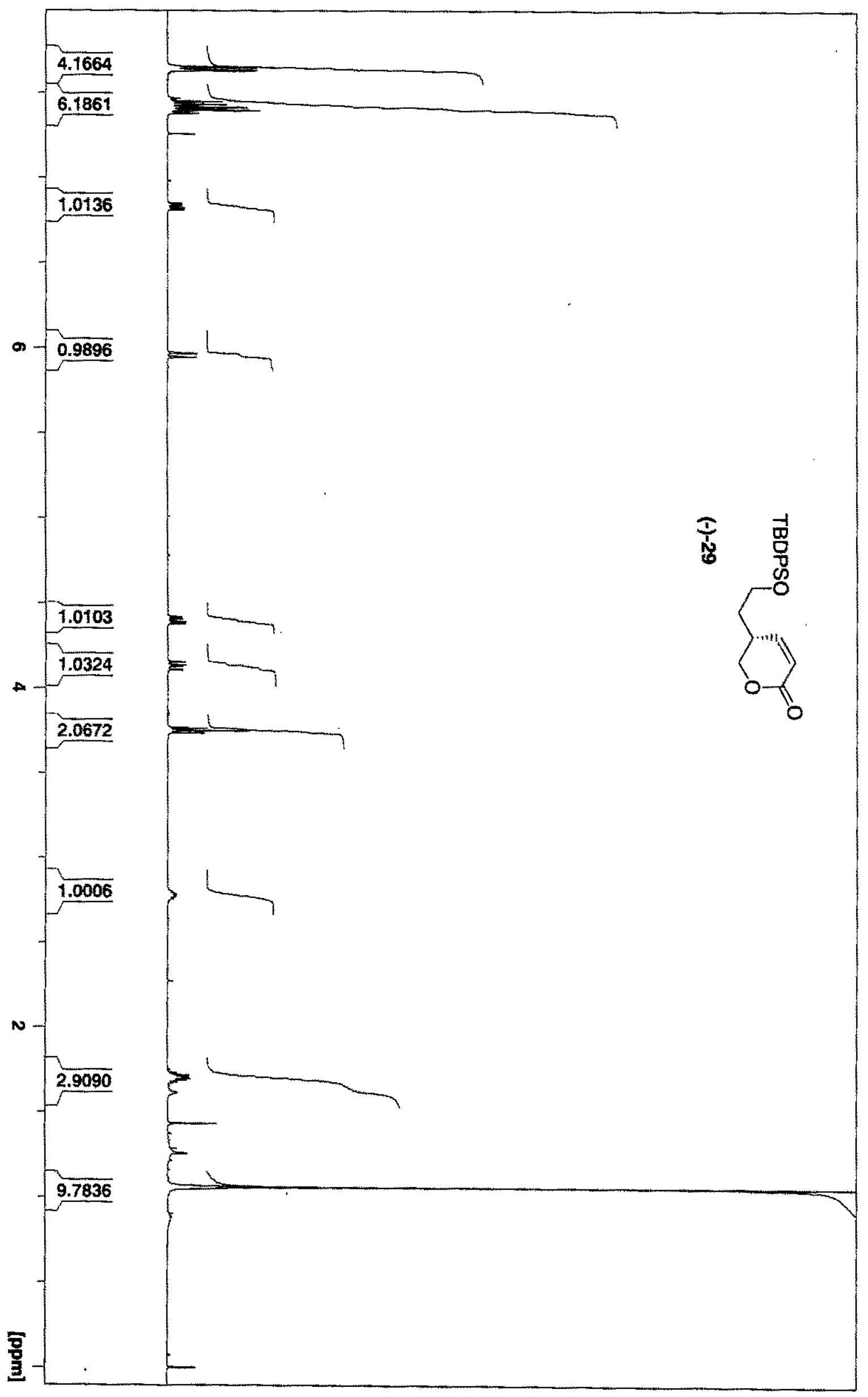




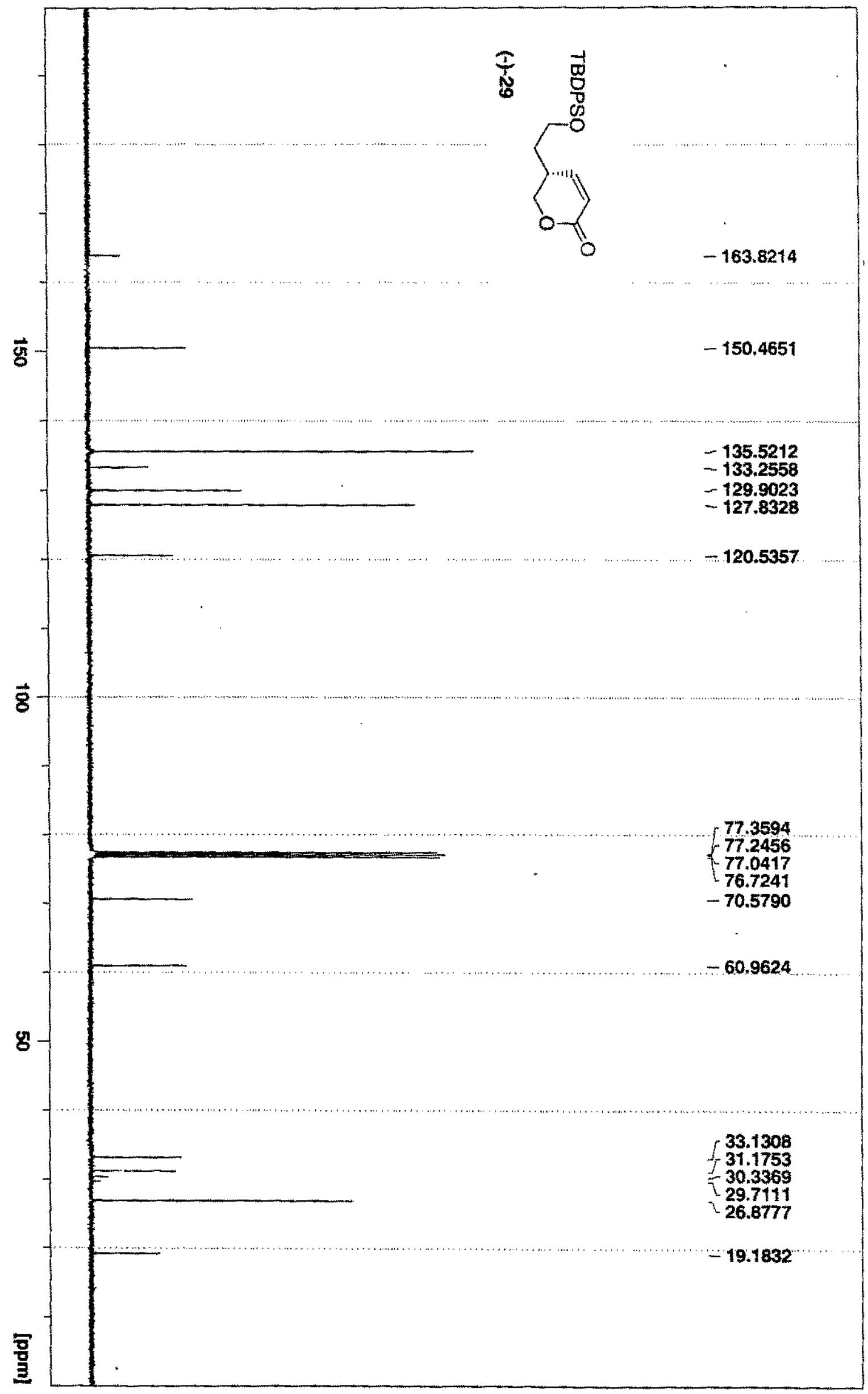




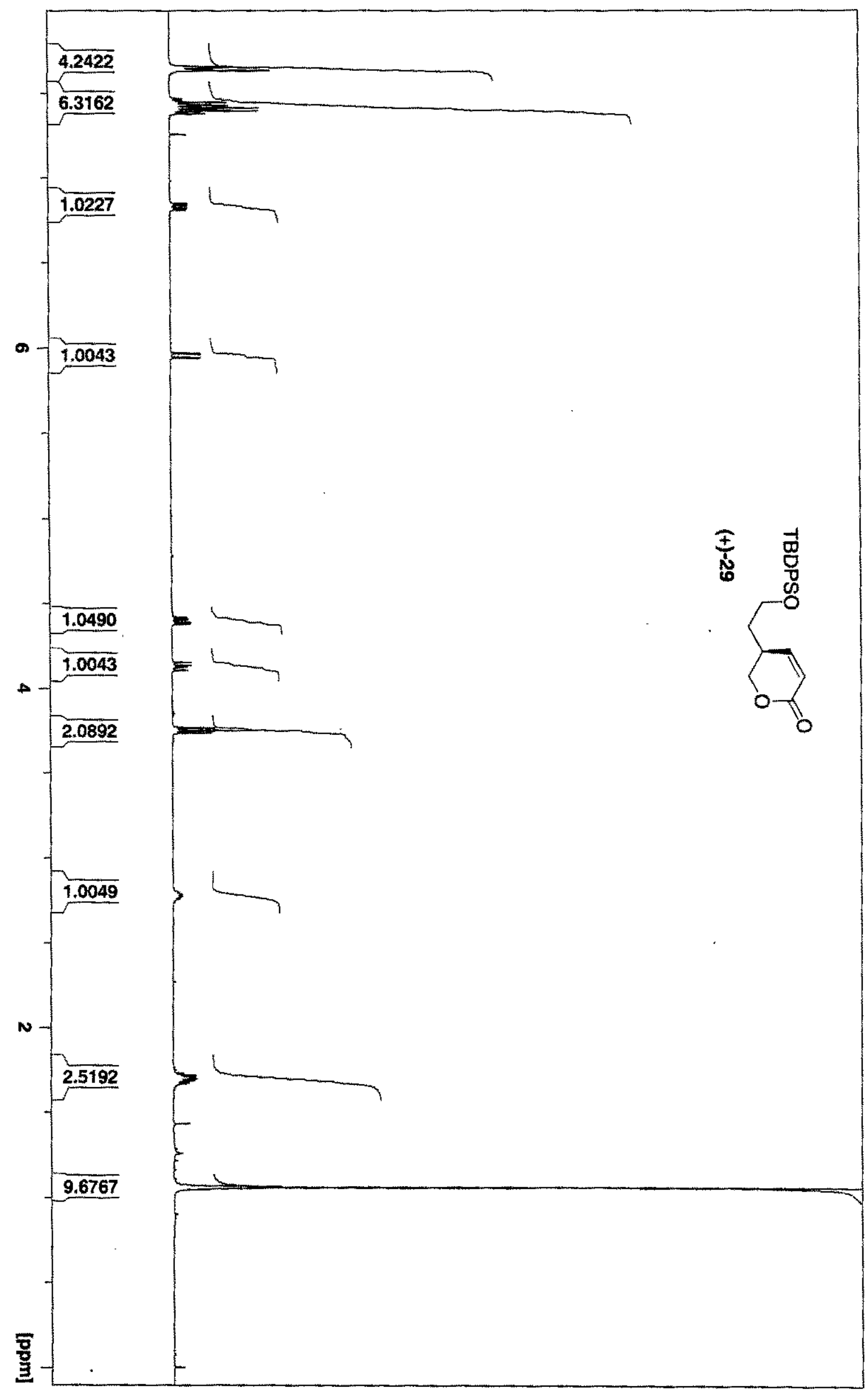




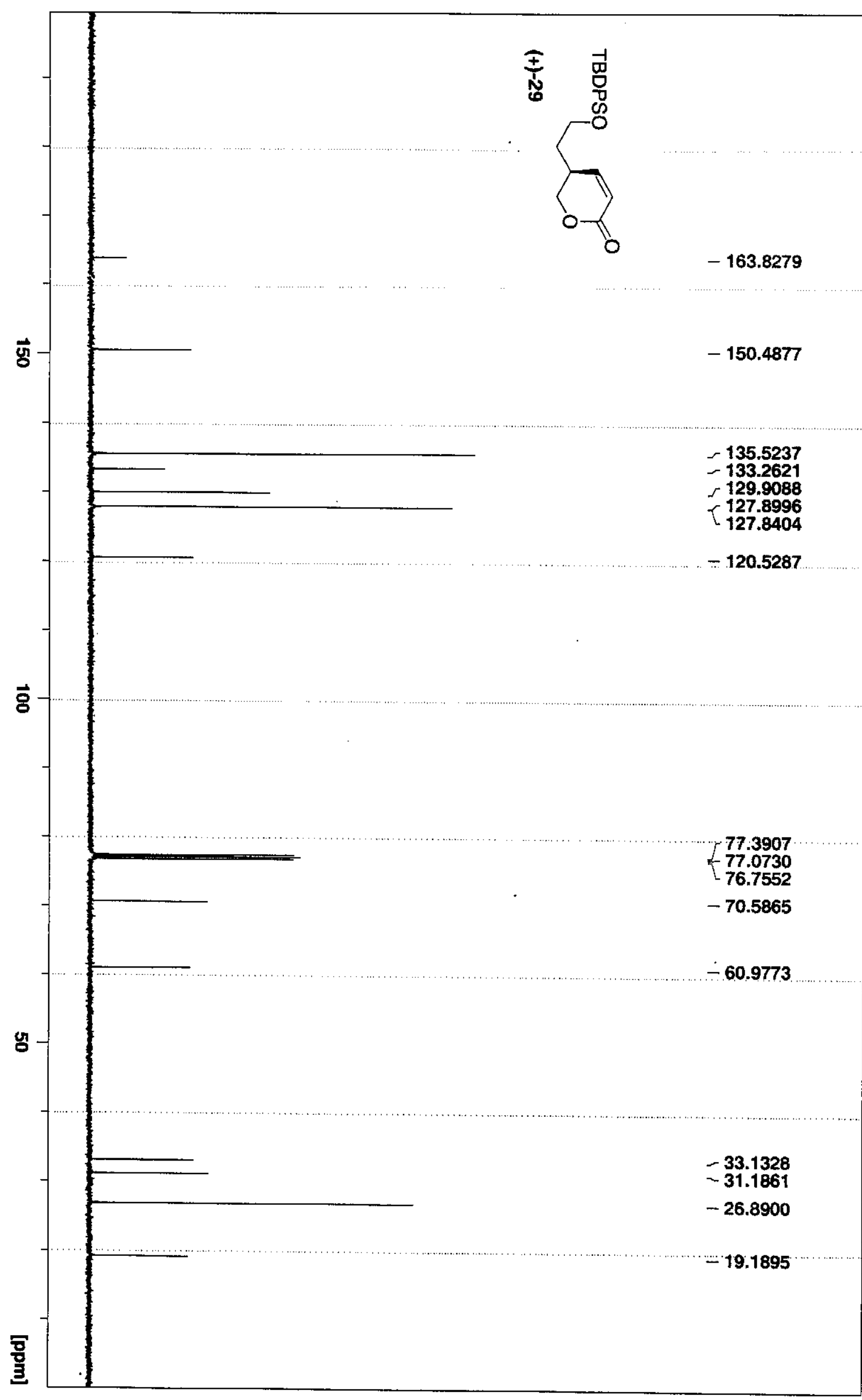




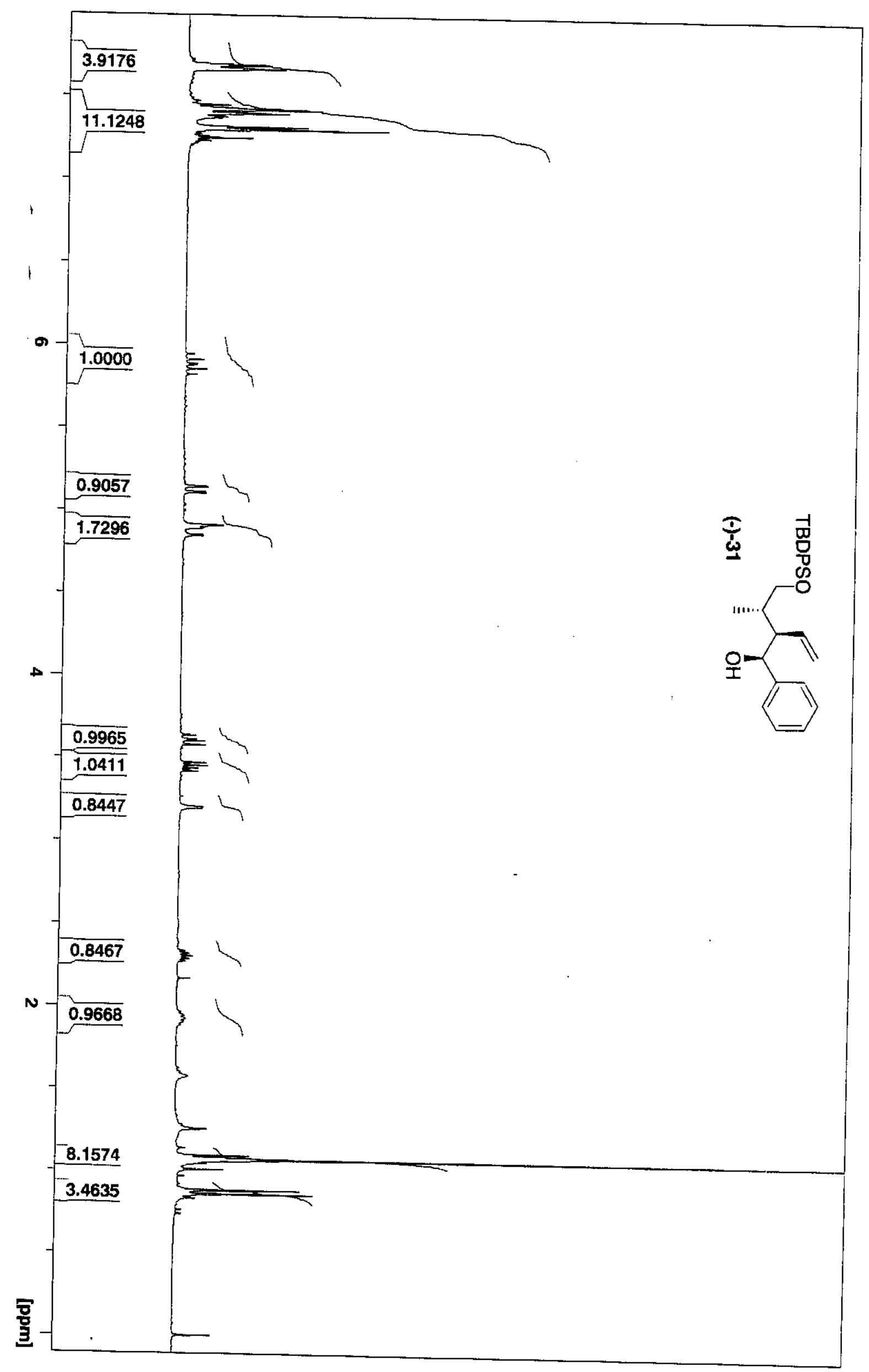




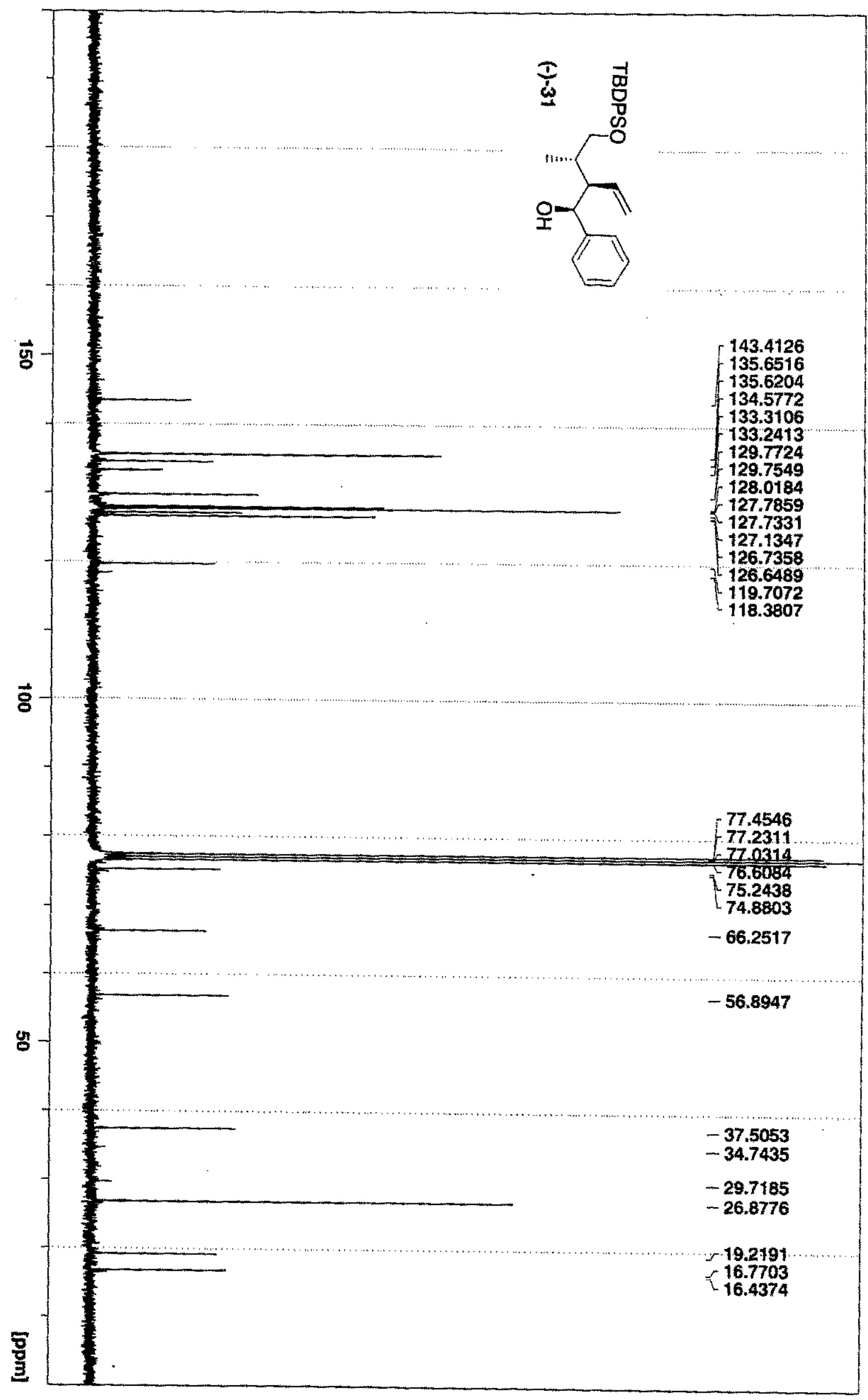




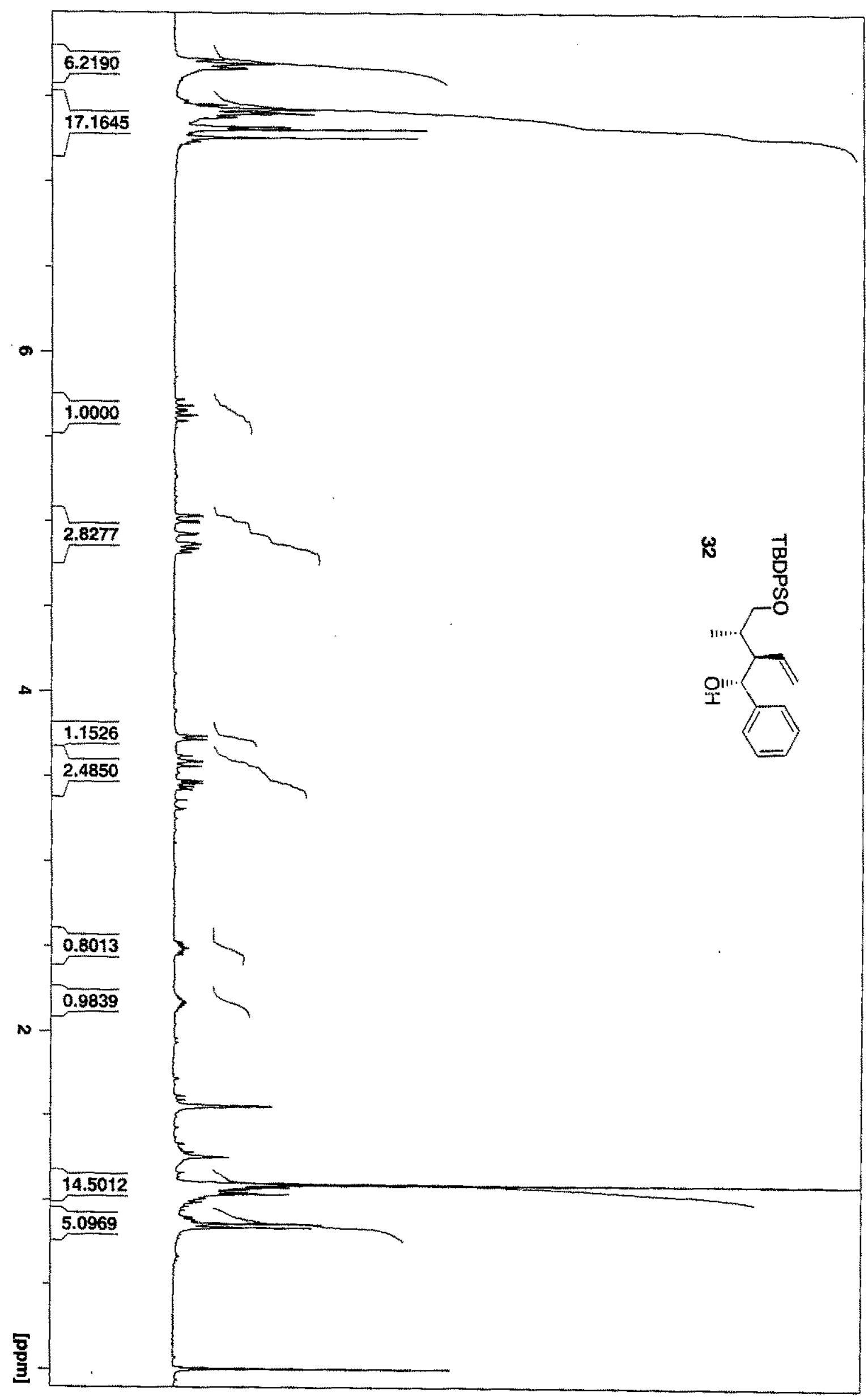




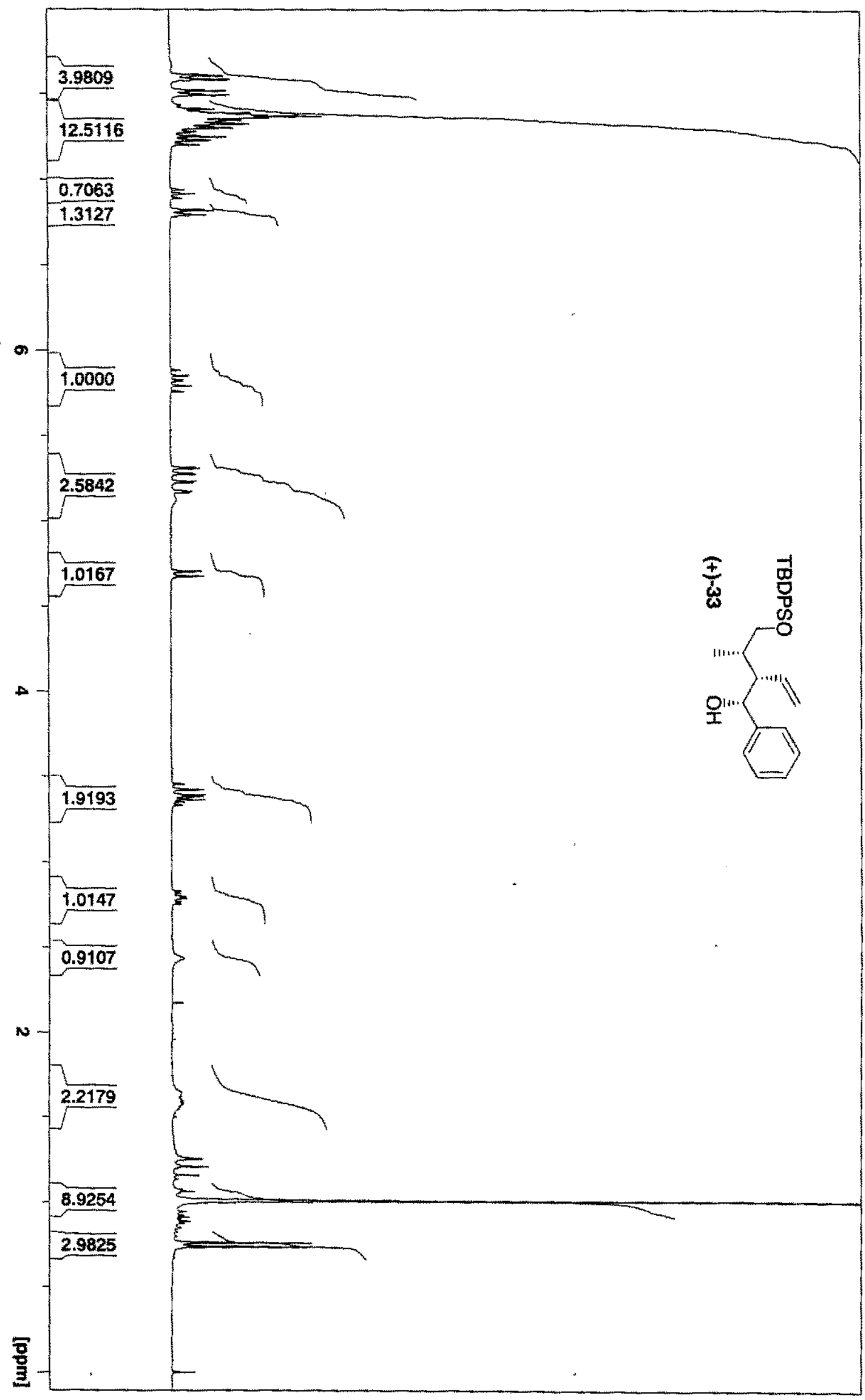




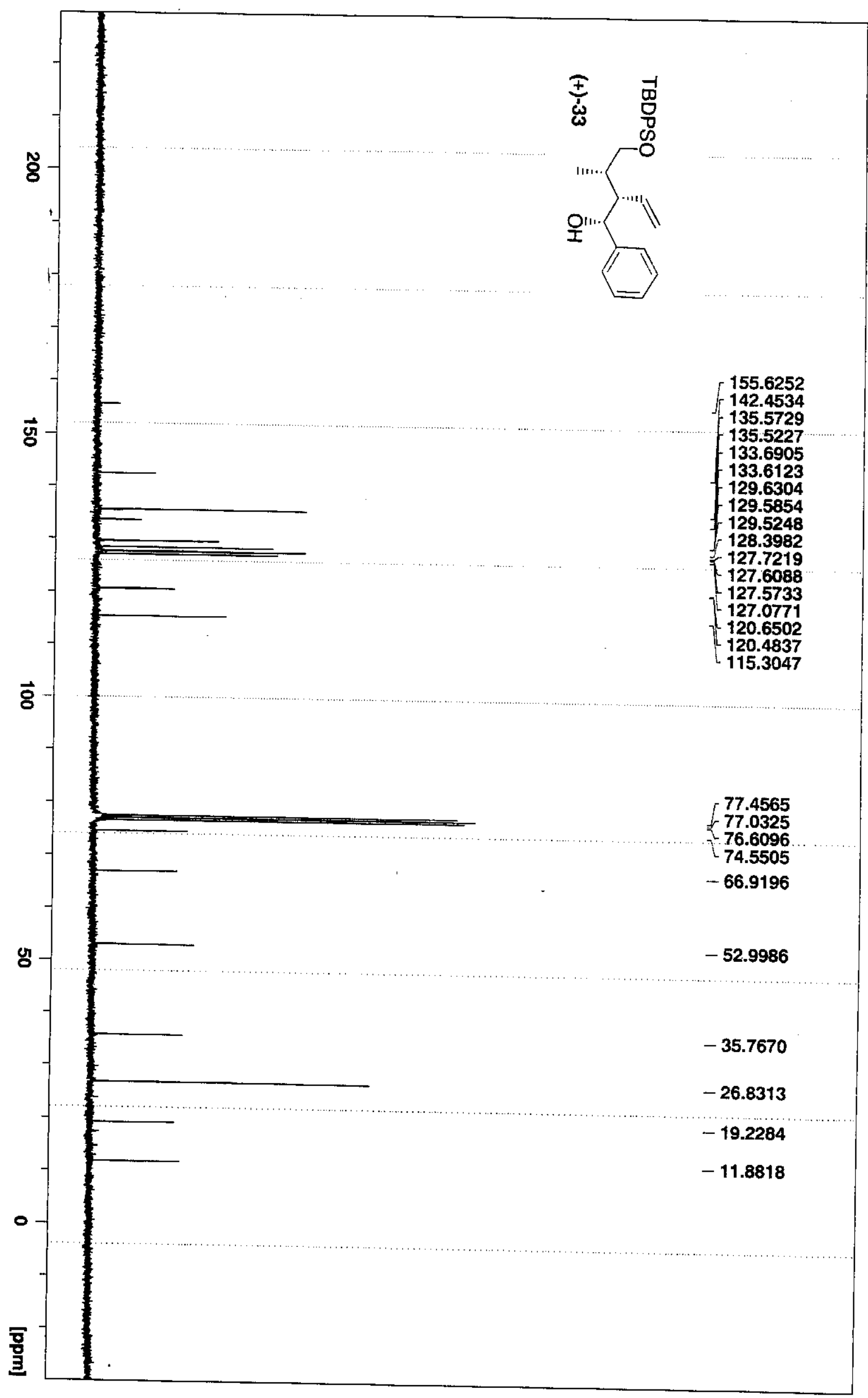




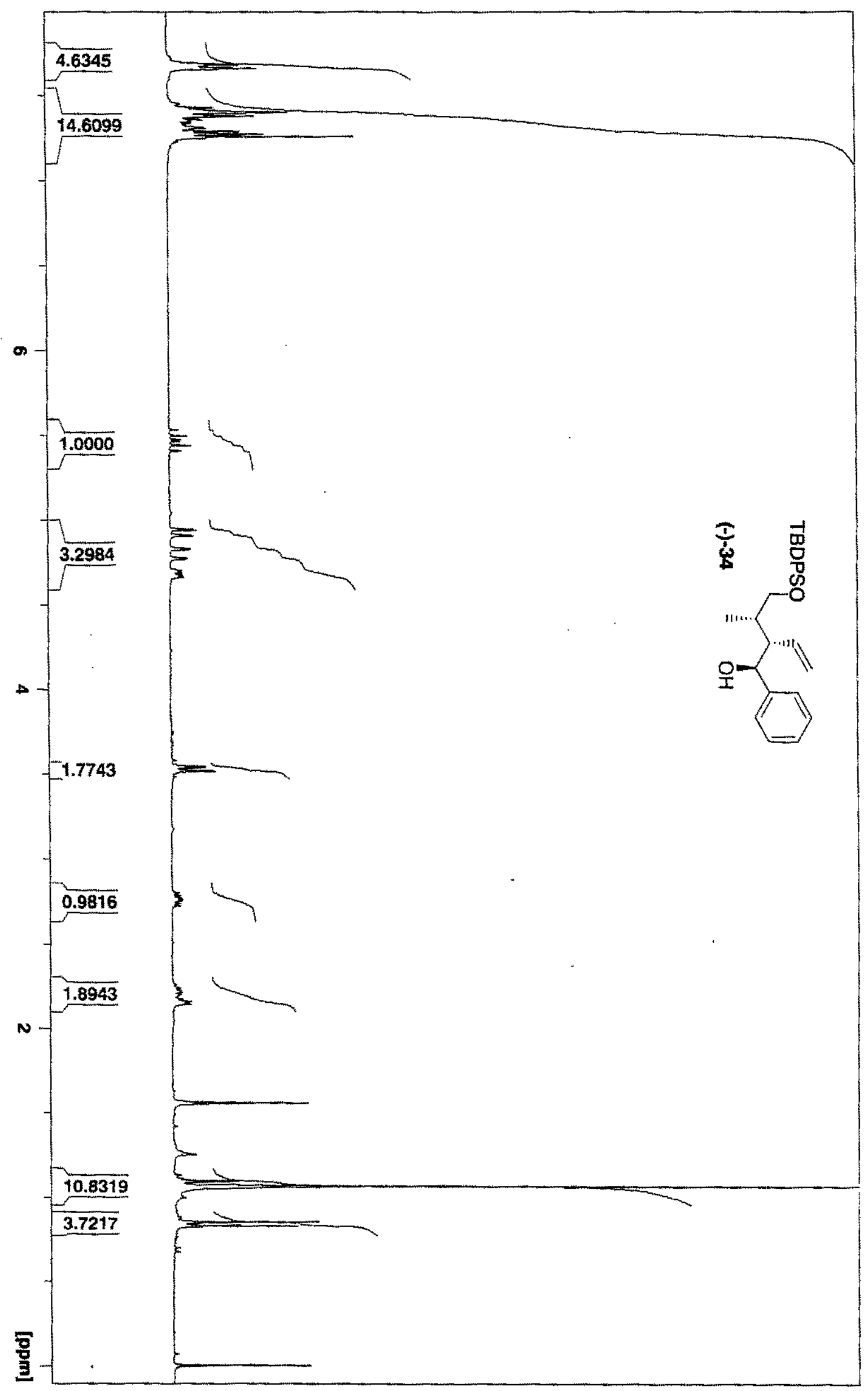




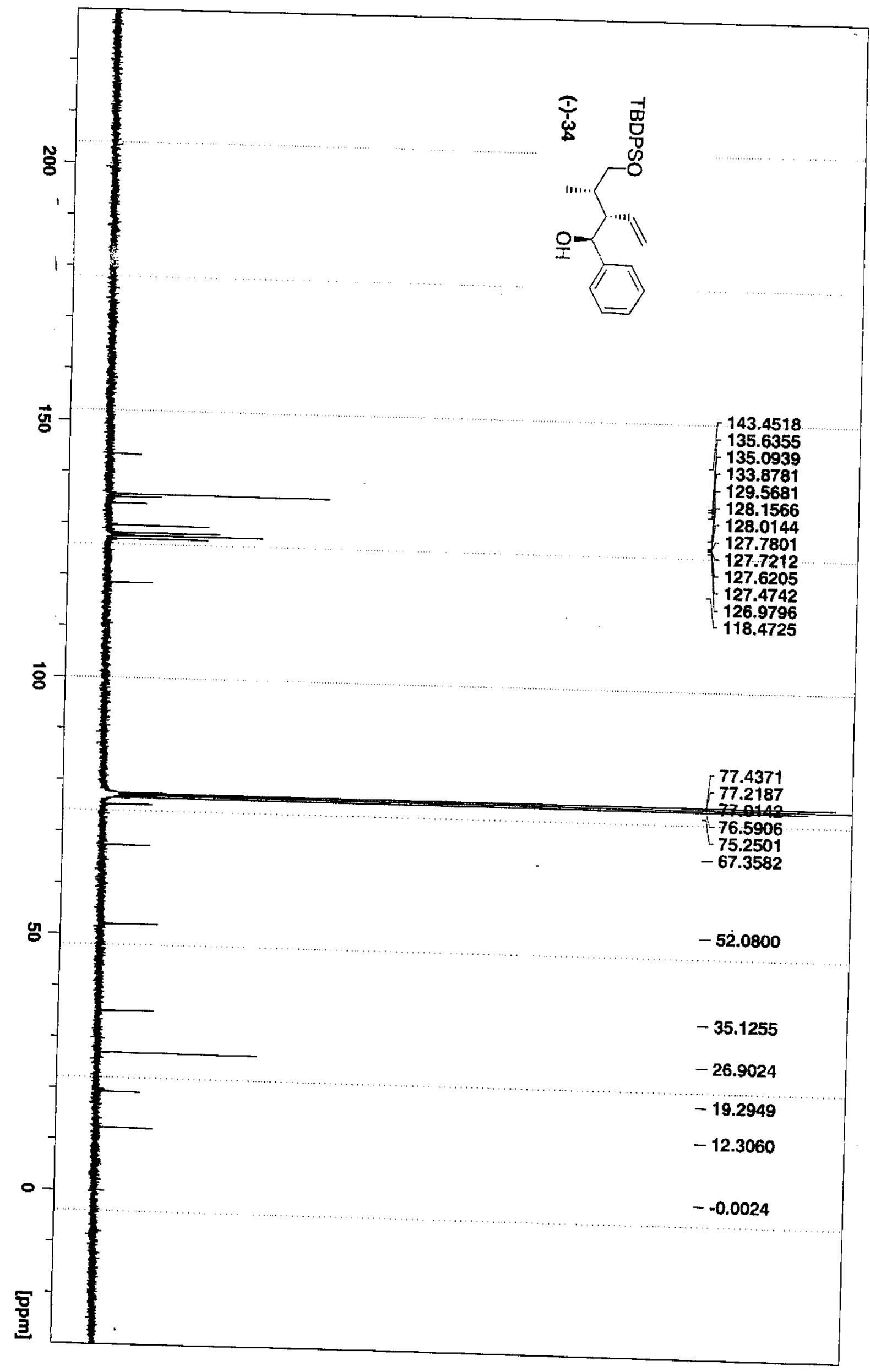

